UNIVERSIDADE DE SÃO PAULO

ESCOLA DE ENGENHARIA DE SÃO CARLOS

DEPARTAMENTO DE ENGENHARIA DE PRODUÇÃO

Caroline Teixeira de Barros Moraes

\title{
APRENDIZAGEM ORGANIZACIONAL NA PEQUENA EMPRESA: \\ PROPOSTA DE UM MAPA CONCEITUAL
}

São Carlos 



\section{CAROLINE TEIXEIRA DE BARROS MORAES}

\section{APRENDIZAGEM ORGANIZACIONAL NA PEQUENA EMPRESA: PROPOSTA DE UM MAPA CONCEITUAL}

Dissertação apresentada à Escola de Engenharia de São Carlos, da Universidade de São Paulo, como parte dos requisitos para obtenção do título de Mestre em Engenharia de Produção.

Área de concentração: Economia,

Organizações e Gestão do Conhecimento

Orientador: Prof. Associado Edmundo Escrivão Filho

\section{São Carlos}


AUTORIZO A REPRODUÇÃO TOTAL OU PARCIAL DESTE TRABALHO, POR QUALQUER MEIO CONVENCIONAL OU ELETRÔNICO, PARA FINS DE ESTUDO E PESQUISA, DESDE QUE CITADA A FONTE.

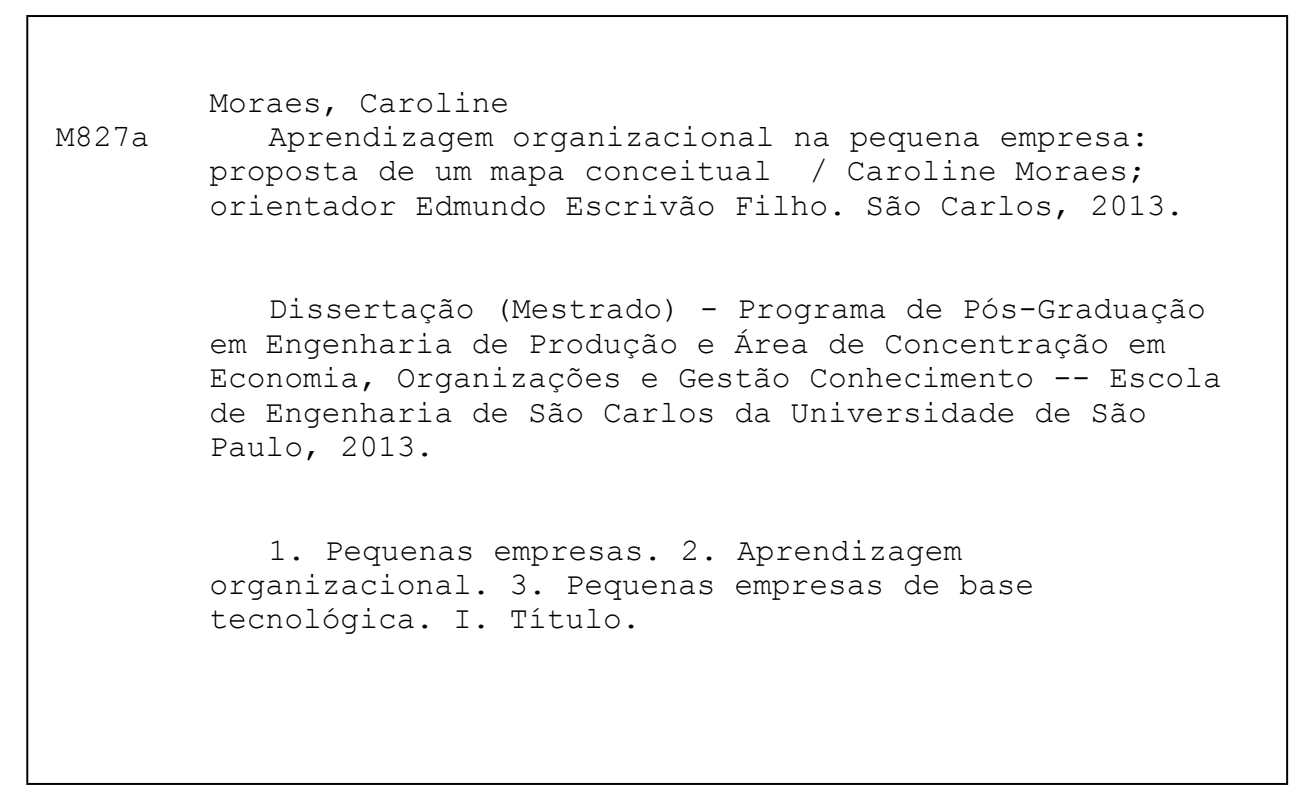




\section{FOLHA DE JULGAMENTO}

Candidata: Engenheira CAROLINE TEIXEIRA DE BARROS MORAES..

Título da dissertação: "Aprendizagem organizacional na pequena empresa: proposta de um mapa conceitual a partir da síntese teórica e de um estudo de caso em empresa de base tecnológica em São Carlos - SP".

Data da defesa: $12 / 03 / 2013$

\section{Comissão Julgadora:}

Prof. Associado Edmundo Escrivão Filho (Orientador)

(Escola de Engenharia de São Carlos/EESC)

Prof. Dr. Sérgio Perussi Filho

(Centro Universitário Central Paulista/UNICEP)

Prof. Associado Sérgio Luis da Silva

(Universidade Federal de São Carlos/UFSCar)
Resultado:
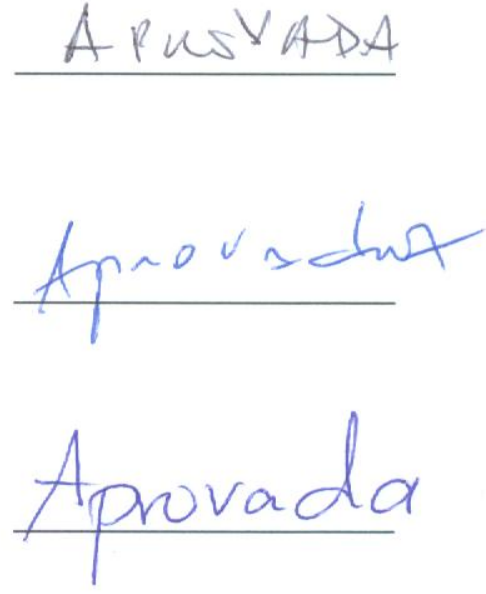

Coordenador do Programa de Pós-Graduação em Engenharia de Produção:

Prof. Titular Henrique Rozenfeld

Presidente da Comissão de Pós-Graduação:

Prof. Titular Denis Vinicius Coury 



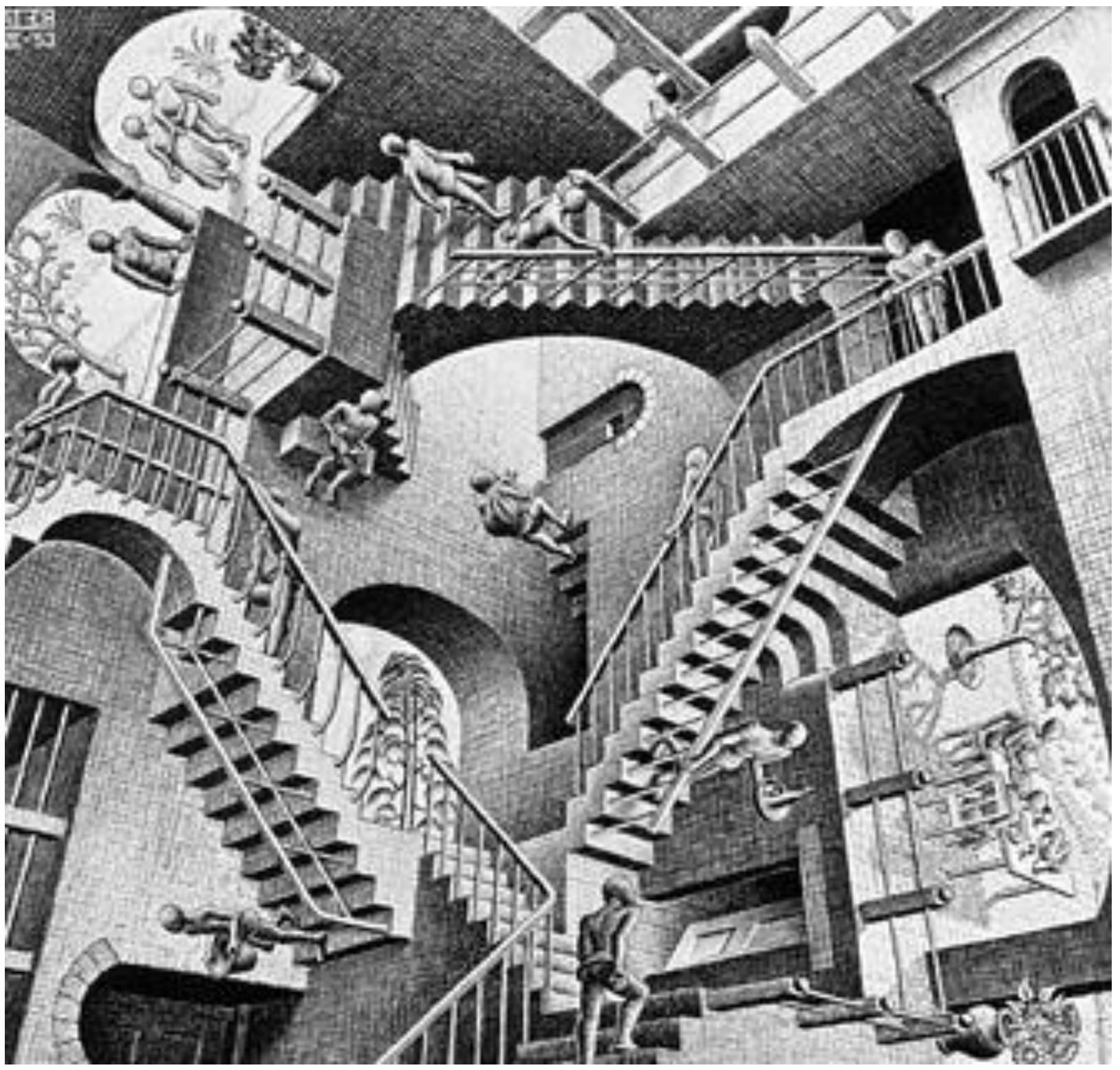

Relativity (Impressão de litografia de M. C. Escher, 1953)

\section{Dedicatória}

Dedico este trabalho ao Daniel e à Luciana. Sem a sua generosidade e a sua fé em mim eu não teria subido o primeiro degrau.

E à Eliete.

Sem a sua mão firme me apoiando eu teria caído da escada. 


\section{AGRADECIMENTOS}

A "Relatividade" de Escher representa, para mim, o universo acadêmico. Pessoas constroem caminhos diferentes e entrecortados para atingirem patamares diversos de conhecimento. Sou profundamente agradecida ao professor Edmundo, não apenas por compartilhar essa visão, mas por oferecer sabedoria e paciência suficientes para permitir que eu escolha a minha "escada" e ainda orientar-me em uma direção constante. O senhor é um educador único e insubstituível, professor.

Agradeço também aos meus pais. Discutir com você sempre me torna uma pessoa melhor, pai. E eu sei que eu posso, por que você sempre estará lá. Sem você eu não teria aprendido a sonhar. Obrigada, mãe, por me ensinar que sonho sem força e perseverança é só uma palavra bonita. E agradeço aos meus irmãos, Cláudia e Daniel, pela dose de bomsenso. Sem vocês eu já estaria perdida no "mundinho de Carol" há muito tempo.

Sou especialmente grata aos colegas do GEOPE, em especial ao Alexandre (meu guru!), à Daniela (anjo da guarda), ao Fábio (companheiro de elucubrações), à Lie (amiga para todas as horas), à Heloísa, ao Paulo, à Kris e ao Sérgio, sem os quais esse trabalho jamais teria sido completado. Vocês serviram de corrimão, construíram degraus inteiros, me apoiaram quando estava prestes a cair. Há muito de vocês em todo esse texto.

Esse trabalho também não seria possível sem o interesse, a confiança e a parceria do Mardoqueu e a hospitalidade e a paciência do Emery, do Cauanã, do Diego, do Charles e do Michel. A todos da BioPDI e da Victor Vision os meus sinceros agradecimentos pela ajuda e generosidade. Espero revê-los em breve!

Agradeço também aos professores Sérgio Luis da Silva e Sergio Perussi Filho pela dedicação e carinho com que leram o meu trabalho. Suas contribuições foram inestimáveis e certamente se refletirão ao longo do doutorado também. Aproveito para agradecer também a Claudete, a Thais e a Jessyca, por muita, mas muita paciência. E muita, muita boa-vontade. Vocês foram as "mãos invisíveis" conduzindo esse trabalho.

Aos amigos agradeço a presença sempre reconfortante, mesmo que à distância, e o apoio incondicional. Torcida não ganha o jogo, mas faz muita diferença.

Por fim, agradeço diariamente aos meus minhas sobrinhos Isabelle (BFF!), Maria Luiza e Eduardo, meus lembretes constantes das maravilhas à nossa volta, do quanto ainda há por desvendar, da importância da curiosidade pura e indisciplinada, da alegria da descoberta.

Amo muito vocês. 
"Only the curious

have, if they live, a tale worth telling at all"

Alastair Reed 



\section{RESUMO}

MORAES, Caroline Teixeira de Barros (2013). Aprendizagem Organizacional na Pequena Empresa: proposta de um mapa conceitual. 127 p. Dissertação (Mestrado) Escola de Engenharia de São Carlos, Universidade de São Paulo, São Paulo. 2013.

O objetivo principal deste trabalho é construir um mapa conceitual, informado pelas "Teorias de Aprendizagem Organizacional", que represente os processos de aprendizagem organizacional na realidade da pequena empresa. O tema geral da pesquisa é a aprendizagem organizacional, sobre o qual foi realizada uma busca sistemática e uma revisão do estado da arte da literatura. O tema específico da pesquisa é a aprendizagem organizacional na pequena empresa, sobre o qual ainda parece haver uma lacuna importante na bibliografia, principalmente nas publicações brasileiras. Assim, a revisão bibliográfica do tema específico foi realizada primariamente sobre o tema mais amplo "pequena empresa", utilizando a abordagem segundo a qual a pequena empresa apresenta algumas especificidades que podem ser compreendidas em três dimensões: o dirigente, a organização e o ambiente. O questionamento central da pesquisa é "Como mapear a aprendizagem organizacional em relação às especificidades da pequena empresa?" Para responder a esse questionamento a pesquisa foi desenvolvida em três etapas: primeiramente foi construído o mapa conceitual representativo dos processos de aprendizagem organizacional encontrados na pequena empresa, partindo da revisão bibliográfica. O mapa é composto por dois construtos principais, a aprendizagem vertical e a aprendizagem horizontal, que orientaram a segunda etapa, a pesquisa de campo. Dada a natureza subjetiva do fenômeno a ser estudado foi adotada uma postura subjetivistainterpretativa. $\mathrm{O}$ método escolhido foi o estudo de caso instrumental único, que permite uma análise profunda o suficiente para a geração de novos conceitos, apoiada em entrevistas realizadas com todos os envolvidos nas atividades da empresa e na observação do seu cotidiano de trabalho. A empresa escolhida é uma pequena empresa de base tecnológica considerada inovadora, para aumentar a expectativa de ocorrência dos processos de aprendizagem. Para finalizar foi apresentada, na terceira etapa do trabalho, a proposta final de um mapa de aprendizagem organizacional na pequena empresa, após a verificação empírica da adequação conceitual dos construtos de aprendizagem vertical e aprendizagem horizontal. Os dados colhidos em campo confirmam a coerência interna do mapa, e indicam os principais caminhos para futuro aperfeiçoamento.

Palavras-chave: Aprendizagem organizacional. Pequenas empresas. Pequenas empresas de base tecnológica. 


\section{ABSTRACT}

MORAES, Caroline Teixeira de Barros (2013). Organizational learning in small firms: proposal for a conceptual map. 127 p. Dissertation (Masters) - Escola de Engenharia de São Carlos, Universidade de São Paulo, São Paulo. 2013.

The main purpose of this study was the construction of a conceptual map, informed by "Learning Organization Theories", representing the organizational learning processes within the reality of small firms. The main research subject was organizational learning. A systematic research and a state of the art review of the literature were undertaken. The specific research subject was organizational learning in small firms. There still seems to be a gap in the literature on this subject, mainly in Brazilian literature. Therefore, the review of the literature was performed mainly on the subject "small business". An approach through which small businesses present some specificities which can be understood in three dimensions: the owner-manager, the environment and the organization was employed. The main research question was: "how to map organizational learning according to the specificities of small firms?" In order to answer this question a three step study was designed: first a "map" (interpretation frame) representing the organization learning processes seen in small firms, built from the review of the literature, was developed. The map contains two main constructs: vertical learning and horizontal learning, which were, secondly, used to guide field research. Given the subjective nature of the phenomenon studied a subjective-interpretative approach was taken. A single case was chosen to allow a deep enough analysis of the concepts involved. The analysis was based on interviews of all members of the firm and on the observation of their daily activities. A technology-based, innovative business was chosen, therefore, to increase the likelihood of learning processes taking place. Thus, on the third stage of the study a final proposal for a conceptual map of organizational learning in small firms was developed, after the empirical evaluation of the conceptual fit of the vertical and horizontal learning constructs. Field data confirmed the internal coherence of the map and indicated possible paths for future development.

Key words: Organizational learning. Small business. Technology-based companies. 


\section{Lista de Figuras}

Figura 1.1 Relação entre aprendizagem organizacional, inovação e criação de valor .. 19

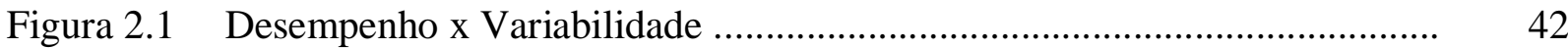

Figura 2.2 Efeito da aprendizagem adaptativa .......................................................... 43

Figura 2.3 Efeito da aprendizagem generativa ..........................................................

Figura 3.1 Ilustração dos subprocessos de aprendizagem organizacional ...................... 48

Figura 3.2 Equifinalidade de sistemas: o código da organização se altera independentemente dos subprocessos executados ....................................................... 49

Figura 3.3 Ilustração de aprendizagem organizacional .............................................. 50

Figura 3.4 Mapa conceitual dos Componentes da Aprendizagem Organizacional (Aprendizagem Horizontal e Aprendizagem Vertical) .............................. 61

Figura 4.1 Modelo de especificidades da pequena empresa ........................................ 72

Figura 4.2 Modelo de aprendizagem da pequena empresa ....................................... 78

Figura 5.1 Aprendizagem vertical e aprendizagem horizontal no contexto da pequena empresa ................................................................................. 88

Figura 6.1 Os atores das três dimensões da pequena empresa estudada ....................... 105

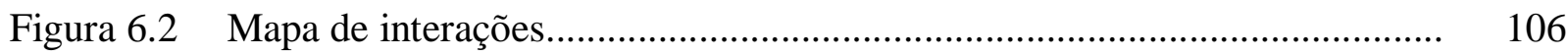

Figura 6.3 Mapa de aprendizagem da empresa estudada ............................................ 106

Figura 7.1 Primeira etapa na construção do mapa de aprendizagem ............................ 110

Figura 7.2 Segunda etapa na construção do mapa de aprendizagem ............................. 110

Figura 7.3 Terceira etapa na construção do mapa de aprendizagem .............................. 111

Figura 7.4 Quarta etapa na construção do mapa de aprendizagem ................................ 111 


\section{Lista de Quadros}

Quadro 1.1 Grupos temáticos para o estado da arte da produção internacional sobre Aprendizagem Organizacional

Quadro 1.2 Grupos temáticos para o estado da arte da produção nacional sobre Aprendizagem Organizacional

Quadro 1.3 Grupos temáticos para o estado da arte da produção internacional sobre Aprendizagem Organizacional nas Pequenas Empresas

Quadro 1.4 Grupos temáticos para o estado da arte ......................................................... 26

Quadro 2.1 Artigos e autores seminais na descrição dos processos de A. O. ................... 35

Quadro 3.1 Componentes de variabilidade e desempenho nas definições de A. O. ........ 52

Quadro 3.2 Formação visual dos construtos de aprendizagem horizontal e vertical ........ 60

Quadro 4.1 Critério de classificação para micro, pequenas, médias e grandes empresas no Brasil, segundo o número de empregados, receita operacional bruta anual e faturamento bruto anual, por grande grupo de atividade econômica...

Quadro 4.2 Especificidades de gestão das pequenas empresas ...................................... 73

Quadro 5.1 Formação visual dos construtos de aprendizagem horizontal e vertical ....... 82

Quadro 5.2 Aprendizagem vertical e aprendizagem horizontal na pequena empresa ...... 86

Quadro 5.3 Protocolo de pesquisa ............................................................................. 91

Quadro 5.4 Roteiro para as entrevistas semi-estruturadas ............................................. 93

Quadro 6.1 Aprendizagem vertical e aprendizagem horizontal na empresa estudada ...... 103

Quadro 7.1 Análise e diagnóstico do mapa de aprendizagem ...................................... 111 


\section{Lista de Tabelas}

Tabela 5.1 Resultados para o tema geral "Aprendizagem Organizacional"

Tabela 5.2 Resultados para o tema particular "Aprendizagem Organizacional nas Pequenas Empresas" 


\section{Lista de Abreviaturas e Siglas}
A. O. Aprendizagem Organizacional
GEOPE Grupo de Estudos Organizacionais da Pequena Empresa
IBGE Instituto Brasileiro de Geografia e Estatística
JCR Journal Citation Reports
PEBT Pequena Empresa de Base Tecnológica
PME Pequena e Média Empresa
RAIS Relação Anual de Informações Sociais
SBA Small Business Administration
SEBRAE Serviço Brasileiro de Apoio às Pequenas Empresas
SECI Socialization, Externalization, Combination and Internalization (Socialização, Externalização, Combinação e Internalização) 


\section{Sumário}

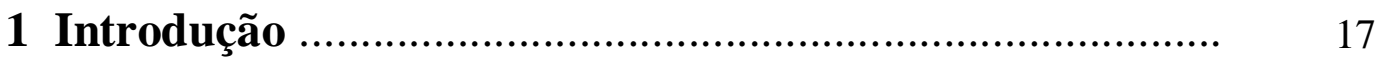

1.1 Contextualização da Pesquisa ........................................................... 17

1.2 Revisão do Estado da Arte do Tema .................................................... 20

1.3 Delimitação do Tema da Pesquisa..................................................... 26

1.4 Formulação do Problema da Pesquisa.................................................. 27

1.5 Declaração dos Objetivos da Pesquisa................................................ 28

1.6 Pressupostos Epistemológicos e Estratégia de Pesquisa...................... 28

1.7 Relevância da Pesquisa...................................................................... 31

1.8 Motivação para a pesquisa................................................................. 31

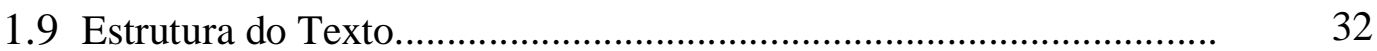

2 Aprendizagem organizacional: conceitos relevantes......... 33

2.1 Definições e Obras Seminais................................................................. 33

2.2 Os Subprocessos da Aprendizagem Organizacional Baseados nas teorias de Huber e Nonaka................................................................................ 36

2.3 Resultados da Aprendizagem Baseados nas teorias de March e

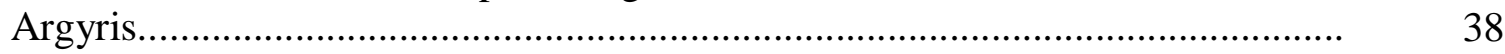

2.6 As Organizações de Aprendizagem e o modelo de Senge................... 44

\section{Proposição de um Mapa Conceitual sobre} Aprendizagem Organizacional .................................................... 47

3.1 Aprendizagem como um Vetor....................................................... 47

3.2 Desempenho e Variabilidade........................................................... 51

3.3 Projeto de Organização de Aprendizagem............................................ 52

3.4 Aprendizagem Horizontal e Aprendizagem Vertical........................... 59

4 Pequenas Empresas: Conceitos Relevantes........................ 63

4.1 Pequenas Empresas e Organizações.................................................... 63

4.2 Caracterização e Tipologia das Pequenas Empresas............................ 64

4.3 As Empresas de Base Tecnológica ...................................................... 69

4.4 O Modelo de Especificidades das Pequenas Empresas....................... 70

4.5 Aprendizagem Organizacional nas Pequenas Empresas ..................... $\quad 75$ 


\section{Sumário (Continuação)}

4.6 Um Modelo de Aprendizagem Organizacional nas Pequenas Empresas.

5 Métodos de Pesquisa.

5.1 Relato da Busca Sistemática........................................................... 79

5.2 Proposição de um Mapa Conceitual para investigar a Aprendizagem Organizacional na Pequena Empresa

5.3 Caracterização e Desenho da Pesquisa.

6 Relatório de Estudo de Caso Único Instrumental............ 95

6.1 Descrição da Empresa.................................................................... 95

6.2 Entrevistas e Observação............................................................... 96

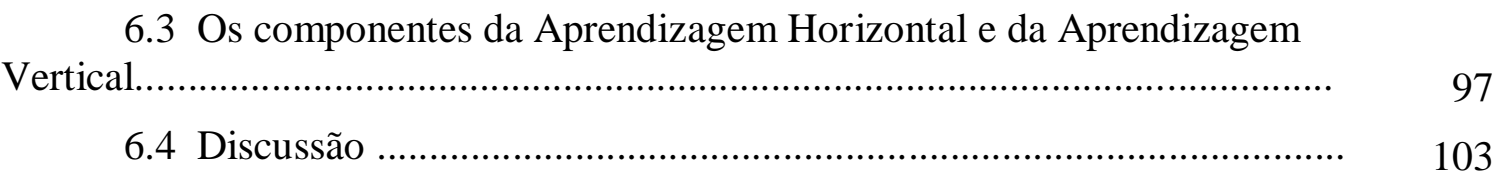

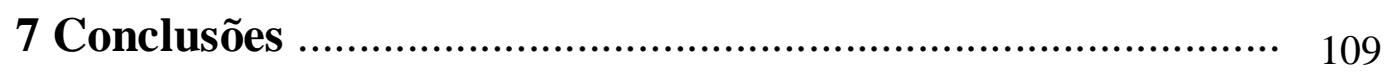

7.1 Formação do mapa conceitual .......................................................... 110

7.2 Diretrizes para aprimoramento do mapa conceitual ............................. 112

7.3 Considerações Finais .................................................................. 113

Apêndice A. Aprendizagem Organizacional: "Vulcão Verde" da Produção Internacional - Artigos Selecionados

Apêndice B. Aprendizagem Organizacional: "Vulcão Verde" da Produção Brasileira - Artigos Selecionados

Apêndice C. Aprendizagem Organizacional na Pequena Empresa: "Vulcão Verde" da Produção Internacional - Artigos Selecionados 


\section{Introduçãa}

O objetivo deste capítulo introdutório é a apresentação do raciocínio empregado na pesquisa para construção do conhecimento, composto de quatro elementos principais: i) a apresentação inicial do contexto subjacente ao problema de pesquisa; ii) a apresentação da fronteira do conhecimento (estado da arte); iii) a relação entre a problematização apresentada e o tema da pesquisa e iv) a definição dos pressupostos epistemológicos adotados.

\subsection{Contextualização da Pesquisa}

O Brasil, que em 2011 conseguiu superar a economia do Reino Unido e tornar-se a sexta economia mundial, deve manter-se pelo menos como a sétima nação mais rica do mundo até 2015, segundo previsões elaboradas pelo Fundo Monetário Internacional (CORREIO DO ESTADO, 2010; DAILYMAIL, 2011). Por outro lado, o país ainda ocupa a $47^{\mathrm{a}}$ posição no ranking mundial de inovação (Global Innovation Index) de 2011, sendo apenas o $3^{\circ}$ colocado na América Latina (INSEAD, 2011).

Além disso, o Brasil vem dependendo cada vez mais da exportação de matérias primas. Em 2009 a exportação de produtos básicos foi superior à de produtos manufaturados, o que não ocorria desde 1978 (ANPEI, 2010). Em 2011 quase metade (47,1\%) das exportações brasileiras decorreram da venda de seis produtos: minério de ferro, petróleo bruto, complexo de soja e carne, açúcar e café (O ESTADO DE S. PAULO, 2012). Esse quadro indica que a economia brasileira, apesar de estar se desenvolvendo, depende de uma porcentagem muito alta de produtos de baixo valor agregado, o que a torna demasiado dependente da flutuação de preços de commodities. Esse dado pode representar um entrave ao crescimento econômico sustentado do país, já que os investimentos em inovação não são suficientes para sustentar seu desenvolvimento (ENDEAVOR, 2008; ANPEI, 2010).

A situação é ainda mais crítica em relação às pequenas empresas. Em 2008 elas constituíam 99\% das empresas brasileiras e eram responsáveis por $60 \%$ dos empregos formais, ou seja, englobavam a maior parte da população economicamente ativa; entretanto, representavam apenas 20\% do PIB nacional (BRASIL, 2012). Esse numero reflete a baixíssima agregação de valor representada pelas pequenas empresas: $80 \%$ do PIB é gerado por apenas $1 \%$ das empresas do país, todas grandes organizações. Além disso, esse dado é um 
importante indicador do nível de concentração de renda. A falta de investimentos em inovação e em produtos de maior valor agregado, principalmente nas pequenas empresas, reduz suas margens, o que implica salários menores para uma grande parcela da população ativa brasileira. No setor de comércio e serviços, por exemplo, os salários pagos pelas micro e pequenas empresas, em 2001, correspondiam a apenas 39\% daqueles pagos nas médias e grandes empresas (SENAC-RS, 2010).

Na última década várias medidas foram tomadas para minimizar o problema, como a publicação de leis de incentivo à inovação (a "Lei da Inovação", de 2004, e a "Lei do Bem", de 2005), o enfoque dado ao tema "inovação" pelas agências de fomento e apoio ao empreendedorismo (SEBRAE, 2010) e uma quantidade grande de novas linhas de crédito subsidiado oferecidas a empreendedores inovadores (FINEP, 2010). Conversas da pesquisadora com empreendedores e dirigentes de micro e pequenas empresas, entretanto, indicam que, embora haja recursos e diretrizes gerais no sentido de promover a inovação, parece haver uma lacuna de conhecimento em relação a este assunto, ou seja, uma boa parcela dos dirigentes de micro e pequenas empresas sabe que é importante inovar, mas não sabe como fazê-lo.

As dificuldades já se manifestam na aparente dificuldade em se aceitar uma definição comum de "inovação". Seria o resultado do desenvolvimento tecnológico? A criação de novos modelos de negócios? O lançamento de novos produtos? Uma nova configuração para a cadeia de valor da empresa? É importante considerar que "inovação" é apresentada, no contexto acima exposto, como a resposta para o problema de agregação de valor e de criação de vantagem competitiva. Nesse caso é interessante considerar inovação de forma abrangente, como a introdução do novo, considerando seu impacto sobre o desempenho da empresa, do mercado e do setor (JOHANNESSEN; OLSEN; LUMPKIN, 2001). Assim, a resposta de "como fazer inovação" centraliza-se na procura dos processos essenciais para a introdução de um "novo" que se manifeste no desempenho e na competitividade da empresa.

A aprendizagem organizacional parece ser um dos processos que melhor responde à pergunta "como introduzir o novo". A aprendizagem organizacional (aprendizado contínuo e interativo) configura-se como o processo mais importante para o desenvolvimento da inovação tecnológica (TOMAÉL; ALCARÁ; DI CHIARA, 2005). García-Morales e LlorénsMontes (2007), em um estudo quantitativo envolvendo pequenas e grandes empresas, demonstraram uma alta correlação entre a capacidade de aprendizagem das empresas e sua capacidade de inovação, e uma alta correlação entre a presença de inovação e o desempenho das empresas. Como Kontoghiorghes e Awbre (2005, p. 185) resumem: 
Líderes e teóricos das organizações cada vez mais consideram o aprendizado como o elemento chave no desenvolvimento e na manutenção de vantagem competitiva. (ARMSTRONG e FOLEY, 2003; BALDWIN, DANIELSON, e WIGGENHORN, 1997; DEGEUS, 1988; GOH e RICHARDS, 1997; LIEDTKA, 1996; NONAKA, 1991; PORTH, MCCALL, e BAUSCH, 1999; SCHEIN, 1993; SENGE, 1990A; SLATER e NARVER, 1995; STATA, 1989). Embora a aprendizagem organizacional venha sendo estudada há décadas (ARGYRIS e SCHÖN, 1978, 1996), surge uma nova ênfase em relação ao aprendizado, gerada pelas mudanças rápidas no ambiente de negócios, incluindo condições incertas de mercado, aumento da complexidade, alterações demográficas e competição global (ALTMAN e ILES, 1998; PETERS, 1987; PROBST e BUCHEL, 1997; SWAIN, 1999).

Outro ponto importante a ser considerado: alguns conceitos prevalentes na teoria de inovação, como a análise de processos baseada na distinção entre inovações radicais e inovações incrementais e os métodos de gestão de portfólio baseados em modelos financeiros ou de mercado interno (DAVILA; EPSTEIN; SHELTON, 2007; TIDD; BESSANT; PAVITT, 2008), não parecem encontrar respaldo nas práticas de empresas reconhecidamente inovadoras (informação verbal). Essa distância entre teoria e prática pode indicar, novamente, a necessidade de uma avaliação mais cuidadosa dos processos subjacentes à inovação e à tomada de decisões relacionadas à inovação, ou dos "antecedentes" da inovação: orientação para o mercado e aprendizagem organizacional (HURLEY; HULT, 1998). Assim, neste texto é adotada a premissa de que o entendimento do tema geral "processo de aprendizagem" é fundamental para responder a pergunta abrangente "como implementar inovação?" Assim, o tema do trabalho não é a inovação propriamente dita, mas seu processo básico: a aprendizagem organizacional. A Figura 1.1 ilustra a relação entre aprendizagem organizacional, inovação e valor, que constitui a premissa básica deste trabalho.

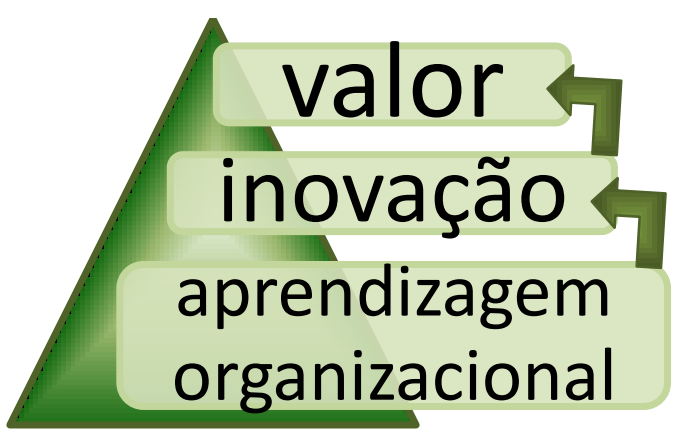

Figura 1.1 - Relação entre aprendizagem organizacional, inovação e criação de valor 


\subsection{Revisão do Estado da Arte do Tema}

\subsubsection{Aprendizagem Organizacional}

A primeira etapa para o entendimento do tema geral "processo de aprendizagem" é situar esse tema em relação à produção de conhecimento atual, nacional e internacionalmente.

Em termos acadêmicos, embora o tema "aprendizagem organizacional" tenha sido introduzido nos anos 50, apenas a partir dos anos 70 passou a consolidar-se como campo de estudo independente (LOIOLA; BASTOS, 2003). No Brasil este tema é ainda mais recente: apenas a partir dos anos 80 o assunto passou a ser debatido na comunidade acadêmica (FLEURY; JÚNIOR, 2002). Muitos estudiosos ressaltam a maneira fragmentada com que o tema é até hoje desenvolvido, talvez por causa de sua origem multidisciplinar (derivado das áreas de Psicologia, Sociologia e Administração). Easterby-Smith e Crossan (2000) o comparam a uma paisagem com vulcões, alguns ativos, alguns inativos, mas com potencial para serem reativados.

A navegação por esta "paisagem" deve ser bem orientada, entretanto, para que se tenha uma ampla visão da mesma. Assim, foi desenvolvido e aplicado um método para a busca sistemática de artigos nacionais e internacionais, atribuindo-se um valor de relevância para o artigo (seu "Índice de Relevância"). Esse índice foi criado através da multiplicação simples de índices representando a repercussão do artigo (através do número de citações do mesmo) e sua credibilidade (através do JCR da revista em que foi publicado, para as revistas internacionais, e de um índice relativo ao Web Qualis, para as revistas nacionais). A descrição detalhada do método é fornecida na Seção 7.1.

A aplicação da busca sistematizada para a escolha dos artigos e materiais a serem lidos durante o processo de revisão bibliográfica resultou na seleção de 48 artigos internacionais e 16 artigos brasileiros, considerados os mais relevantes publicados desde 2000 (de acordo com o índice de relevância). Embora alguns artigos tenham abordado mais do que um grande tema, foi possível identificar 6 grandes temas, ou os "vulcões ativos" (EASTERBY-SMITH e CROSSAN; 2000) desta última década. Cinco grandes temas têm abrangência internacional e um sexto tema possui destaque apenas na produção acadêmica brasileira.

Dos 48 artigos internacionais, mais da metade (25 artigos) trata da descrição dos processos (e modelagem) da aprendizagem organizacional: Nonaka e Toyama (2000); Szulanski (2000); Cross e Parker (2001); Gold e Malhotra (2001); King (2001); Örtenblad (2001); Bontis e Crossan (2002); Robey e Ross (2002); Lee e Choi (2003); Antonacopoulou 
(2006); García-Morales e Llorens-Montes (2006); Gourlay (2006); Levinthal e Rerup, (2006); Nonaka e Von Krogh (2006); Schulze e Hoegl (2006); Wang e Ahmed (2007); Garvin e Edmondson (2008); Moodysson e Coenen (2008); Lichtenthaler (2009); Nonaka e Von Krogh (2009); Bell e Menguç (2010); Bresman (2010); Brouwers e Stacey (2010); Madsen e Desai (2010); Yeo e Marquardt (2010).

O segundo grande tema encontrado na revisão do estado da arte (presente em 11 artigos) foi a confirmação da relação direta entre aprendizagem organizacional e desempenho (NONAKA; TOYAMA; KONNO, 2000; BONTIS; CROSSAN; HULLAND, 2002; TIPPINS; SOHI, 2003; GARCÍA-MORALES; LLORENS-MONTES; VERDÚ-JOVER, 2006; POPADIUK; CHOO, 2006; WADHWA; KOTHA, 2006; SKERLAVAJ et al., 2007; LICHTENTHALER, 2009; BRESMAN, 2010; LIAO; WU, 2010; SHIH; CHANG; LIN, 2010).

O terceiro grande tema (presente em 8 artigos) trata dos fluxos de conhecimento dentro das organizações, da influência das interações sociais, da cultura organizacional e do contexto sobre a aprendizagem organizacional (LAM, 2000; SCHULZ, 2001; KANG; MORRIS; SNELL, 2007; SKERLAVAJ et al., 2007; ARGOTE; MIRON-SPEKTOR, 2010; FANG; LEE; SCHILLING, 2010; HORWITZ, 2010; SKERLAVAJ et al., 2010).

O quarto grande tema (presente em 6 artigos) trata da aprendizagem interorganizacional, estudando os impactos da distribuição geográfica, da formação de clusters e da formação de parcerias na construção do conhecimento entre empresas (HITT et al., 2000; BATHELT; MALMBERG; MASKELL, 2004; SAMADDAR; KADIYALA, 2006; CHUA; PAN, 2008; CSASZAR; SIGGELKOW, 2010; DEKKER; ABBEELE, 2010).

Os quatro artigos restantes estabelecem o quinto e último grande tema discutido atualmente pela comunidade internacional: a relação entre a teoria da aprendizagem organizacional e a sua aplicação prática. Dois artigos relatam estudos de caso de aplicação das teorias de aprendizagem organizacional (BROWN; BRUDNEY, 2003; GILES; HARGREAVES, 2006), enquanto outros dois discutem as dificuldades de fazer esta transposição entre teoria e prática (RYNES; BARTUNEK; DAFT, 2001; GRAHAM et al., 2006).

O Apêndice A contém a tabela final gerada pela aplicação do método de busca sistemática nesta etapa, com os dados relevantes sobre cada um dos 25 artigos selecionados para o tema "processos e modelagem da aprendizagem organizacional" (o tema de interesse para este trabalho), além de uma breve descrição dos mesmos. 
O Quadro 1.1 resume os grupos temáticos encontrados. Considerando-se que o índice de relevância seja um bom indicador do interesse no assunto, os temas também foram agrupados por ordem de interesse, de acordo com o número de artigos relevantes encontrados.

\begin{tabular}{|lccr|}
\hline \multicolumn{1}{|c|}{$\begin{array}{c}\text { Aprendizagem Organizacional } \\
\text { (Produção em língua inglesa) } \\
\text { 48 Artigos }\end{array}$} & & \\
\hline \multicolumn{1}{|c|}{ Grupos Temáticos } & Interesse & $\begin{array}{c}\text { No. } \\
\text { Artigos }\end{array}$ & $\%$ \\
\hline $\begin{array}{l}\text { Descrição dos processos e modelagem da aprendizagem } \\
\text { organizacional }\end{array}$ & 1 & 25 & $52 \%$ \\
\hline $\begin{array}{l}\text { Relação direta entre aprendizagem organizacional e } \\
\text { desempenho }\end{array}$ & 2 & 11 & $23 \%$ \\
\hline $\begin{array}{l}\text { Fluxos de conhecimento dentro das organizações - influência } \\
\text { das interações, cultura e contexto }\end{array}$ & 3 & 8 & $17 \%$ \\
\hline Aprendizagem inter-organizacional & 4 & 6 & $13 \%$ \\
\hline Relação entre teoria e prática & 5 & 4 & $8 \%$ \\
\hline
\end{tabular}

Quadro 1.1 - Grupos temáticos para o estado da arte da produção internacional sobre Aprendizagem Organizacional

A produção acadêmica brasileira, representada pelos 16 artigos selecionados através da busca sistemática, segue de forma aproximadamente paralela aos temas internacionais . Metade dos artigos selecionados (8 dos 16) abordam o principal tema no cenário nacional, a relação entre aprendizagem organizacional e desempenho: Fleury e Fleury (2001); Leite e Porsse (2003); Shinyashiki e Trevizan (2003); Cochia e Machado-Da-Silva (2004); JanissekMuniz e Freitas (2005); De Moura e Bitencourt (2006); Perin e Sampaio (2006); Fernandes e Santos (2008).

O tema processos e modelagem da aprendizagem organizacional ocupa segundo lugar em importância, com 4 artigos (LEITE; PORSSE, 2003; SHINYASHIKI; TREVIZAN; MENDES, 2003; BASTOS et al., 2004; BIDO et al., 2010).

Apenas um artigo relaciona cultura e aprendizagem organizacional (VIEIRA, 2004) e outro discute a aplicação prática da teoria, ainda que de maneira mais conceitual do que os estudos de caso apresentados internacionalmente (MADUREIRA; RODRIGUES, 2006).

Também foi encontrado um único artigo (KLOTZLE, 2002) abordando a formação de parcerias estratégicas. Este também é o único artigo que pode ser relacionado ao tema da aprendizagem inter-organizacional. 
Por fim, 3 artigos abordam um sexto tema, não encontrado na produção internacional: a discussão da situação da pesquisa e da edução no país como base para o desenvolvimento (BULGACOV; VERDU, 2001; LOIOLA; BASTOS, 2003; FIORENTINI, 2008).

O Quadro 1.2 resume os grupos temáticos encontrados. Da mesma forma que no Quadro 1.1, os temas também foram agrupados por ordem de interesse, de acordo com o número de artigos relevantes encontrados.

\begin{tabular}{|lccr|}
\hline \multicolumn{1}{|c}{$\begin{array}{c}\text { Aprendizagem Organizacional } \\
\text { (Produção brasileira) } \\
\text { 16 Artigos }\end{array}$} & & \\
\hline \multicolumn{1}{|c|}{ Grupos Temáticos } & Interesse & $\begin{array}{c}\text { No. } \\
\text { Artigos }\end{array}$ & $\%$ \\
\hline $\begin{array}{l}\text { Relação direta entre aprendizagem organizacional e } \\
\text { desempenho }\end{array}$ & 1 & 8 & $50 \%$ \\
\hline $\begin{array}{l}\text { Descrição dos processos e modelagem da aprendizagem } \\
\text { organizacional }\end{array}$ & 2 & 4 & $25 \%$ \\
\hline $\begin{array}{l}\text { Discussão da situação da pesquisa e da educação } \\
\text { Fluxos de conhecimento dentro das organizações - influência } \\
\text { das interações, cultura e contexto }\end{array}$ & 4 & 3 & $19 \%$ \\
\hline Aprendizagem inter-organizacional & 3 & 1 & $6 \%$ \\
\hline Relação entre teoria e prática & 4 & 1 & $6 \%$ \\
\hline
\end{tabular}

Quadro 1.2 - Grupos temáticos para o estado da arte da produção nacional sobre Aprendizagem Organizacional

O Apêndice B contém a tabela final gerada pela aplicação do método de busca sistemática nesta etapa, com os dados relevantes sobre cada um dos 4 artigos selecionados para o tema "processos e modelagem da aprendizagem organizacional" (o tema de interesse para este trabalho), além de uma breve descrição dos mesmos.

\subsubsection{Aprendizagem Organizacional nas Pequenas Empresas}

Da mesma forma que para o tema geral (aprendizagem organizacional) foi feita a seleção dos artigos mais relevantes (de acordo com o índice de relevância), tanto internacional quanto nacionalmente, no que diz respeito à aplicação da teoria de aprendizagem organizacional às pequenas empresas. A pesquisa sobre a produção internacional resultou em uma lista de 32 artigos de maior índice de relevância (ver a Seção 7.1), que puderam ser 
agrupados em quatro grandes grupos temáticos, bastante semelhantes aos do tema geral. O primeiro e principal grupo temático possui 10 artigos relativos à aprendizagem interorganizacional. Nesse caso, entretanto, é dado enfoque à internacionalização e aos efeitos da aprendizagem interorganizacional (TELL, 2000; DE CLERCQ; SAPIENZA, 2003; BORRELLI; PONSIGLIONE, 2005; CEGARRA-NAVARRO, 2005; JONES; MACPHERSON, 2006; BASLY, 2007a; WINTERS; STAM, 2007; BALESTRIN; VARGAS, 2008; GUPTA; MOESEL, 2008; JIANG; JIE, 2009).

O segundo grupo temático, com 8 artigos, é referente aos processos e modelagem da aprendizagem organizacional (CHASTON; BADGER; SADLER-SMITH, 2000; CORTI; STORTO, 2000; KAUTZ; THAYSEN; THANNING VENDELO, 2002; BASLY, 2007b; CEGARRA-NAVARRO; JIMÉNEZ; MARTÍNEZ-CONESA， 2007; SPRAGGON; BODOLICA, 2008; LEACH, 2010; LOPEZ-NICOLAS; SOTO-ACOSTA, 2010).

O terceiro e o quarto grupos possuem o mesmo número de artigos, 6 cada um. $\mathrm{O}$ grupo que aborda a relação entre aprendizagem organizacional e desempenho é bastante semelhante aos seus pares (ver Quadro 1.1 e Quadro 1.2) (CHASTON; BADGER; SADLER SMITH, 2001; THERIN, 2004; GARCÍA-MORALES; LLORÉNS-MONTES; VERDÚ-JOVER, 2007; WINTERS; STAM, 2007; JAVANMARD; SKHAEI, 2009; MICHNA, 2009). Já o grupo que aborda os fluxos de conhecimento dentro das organizações e a influência das interações, cultura e contexto destaca-se pela sua homogeneidade: todos os artigos empregam a metodologia quantitativa com o uso de surveys para demonstrar a correlação entre variáveis ou fatores (tais como cultura, liderança, tamanho e setor, por exemplo) e a capacidade ou as características de aprendizagem das empresas (KYRIAKIDOU; GORE, 2005; CEGARRANAVARRO; DEWHURST, 2007; GRAHAM; NAFUKHO, 2007; GRAHAM; NAFUKHO, 2008; PILLANIA, 2008; NAFUKHO; GRAHAM; MUYIA, 2009).

Por fim, 3 artigos relevantes não se encaixam em nenhum dos grupos anteriores, podendo indicar os "vulcões inativos" de Easterby-Smith e Crossan (2000) ou tendências emergentes: o primeiro avalia a aplicação de testes americanos padronizados em países asiáticos (WANG et al., 2010), o segundo aborda o tema da gestão do conhecimento (UHLANER; ZHOU; TAN, 2007) e o terceiro descreve um processo de interação entre universidades e pequenas empresas para criação de conhecimento (PHILPOTT, 2008).

O Quadro 1.3 resume os grupos temáticos encontrados. Da mesma forma que no Quadro 1.1, os temas também foram agrupados por ordem de interesse, de acordo com o número de artigos relevantes encontrados. 


\begin{tabular}{|lccr|}
\hline \multicolumn{4}{|c|}{$\begin{array}{c}\text { Aprendizagem Organizacional nas Pequenas Empresas } \\
\text { (Produção em língua inglesa) } \\
\text { 32 Artigos }\end{array}$} \\
\hline \multicolumn{1}{|c|}{ Grupos Temáticos } & Interesse & $\begin{array}{c}\text { No. } \\
\text { Artigos }\end{array}$ & $\%$ \\
\hline Aprendizagem inter-organizacional & 1 & 10 & $31 \%$ \\
\hline $\begin{array}{l}\text { Descrição dos processos e modelagem da aprendizagem } \\
\text { organizacional }\end{array}$ & 2 & 8 & $25 \%$ \\
\hline $\begin{array}{l}\text { Relação direta entre aprendizagem organizacional e } \\
\text { desempenho }\end{array}$ & 3 & 6 & $19 \%$ \\
\hline $\begin{array}{l}\text { Fluxos de conhecimento dentro das organizações - influência } \\
\text { das interações, cultura e contexto }\end{array}$ & 3 & 6 & $19 \%$ \\
\hline Outros & 4 & 3 & $9 \%$ \\
\hline
\end{tabular}

Quadro 1.3 - Grupos temáticos para o estado da arte da produção internacional sobre Aprendizagem Organizacional nas Pequenas Empresas

O Apêndice C contém a tabela final gerada pela aplicação do método de busca sistemática nesta etapa, com os dados relevantes sobre cada um dos 8 artigos selecionados para o tema "processos e modelagem da aprendizagem organizacional" (o tema de interesse para este trabalho), além de uma breve descrição dos mesmos.

Não há uma clara polarização geográfica em relação aos trabalhos selecionados pelo Índice de Relevância. Os pesquisadores publicados pertencem, em sua maioria, a universidades americanas, espanholas, francesas e suíças. Já a produção nacional não retornou resultados para aprendizagem em pequenas empresas (ver a Seção 5.1), evidenciando uma lacuna nesta fronteira do conhecimento.

Ao final das três etapas da busca sistemática foram selecionados um total de 37 artigos considerados estado da arte para os temas geral e específico do trabalho. Além disso, a observação do nível de interesse em relação ao tema escolhido confirma a relevância acadêmica da escolha. O Quadro 1.4 compara os temas delimitados em cada uma das três grandes áreas onde a busca sistemática foi aplicada, mostrando que o "vulcão verde", tema deste trabalho, é de grande interesse e relevância, tanto no Brasil como na comunidade internacional, e possui uma lacuna importante, já que não há trabalhos relevantes de aprendizagem organizacional nas pequenas empresas entre as publicações nacionais. 


\begin{tabular}{|c|c|c|c|c|c|c|}
\hline \multirow[t]{2}{*}{ Grupos Temáticos } & \multicolumn{2}{|c|}{$\begin{array}{c}\text { A.O. } \\
\text { (L. Inglesa) }\end{array}$} & \multicolumn{2}{|c|}{$\begin{array}{c}\text { A. O. } \\
\text { (Brasil) }\end{array}$} & \multicolumn{2}{|c|}{$\begin{array}{l}\text { A. O. nas P. E. } \\
\text { (L. Inglesa) }\end{array}$} \\
\hline & Interesse & $\mathrm{N}^{0}$ artigos & Interesse & $\mathbf{N}^{0}$ artigos & Interesse & $\mathrm{N}^{0}$ artigos \\
\hline $\begin{array}{l}\text { Descrição dos processos } \\
\text { e modelagem da A. O. }\end{array}$ & 1 & $50 \%$ & 2 & $25 \%$ & 2 & $25 \%$ \\
\hline $\begin{array}{l}\text { Relação direta entre A. O. } \\
\text { e desempenho }\end{array}$ & 2 & $25 \%$ & 1 & $50 \%$ & 3 & $19 \%$ \\
\hline $\begin{array}{l}\text { Fluxos de conhecimento } \\
\text { dentro das organizações }\end{array}$ & 3 & $19 \%$ & 4 & $6 \%$ & 3 & $19 \%$ \\
\hline $\begin{array}{l}\text { Aprendizagem inter- } \\
\text { organizacional }\end{array}$ & 4 & $6 \%$ & 4 & $6 \%$ & 1 & $31 \%$ \\
\hline $\begin{array}{l}\text { Relação entre teoria e } \\
\text { prática }\end{array}$ & 5 & $6 \%$ & 4 & $6 \%$ & - & - \\
\hline $\begin{array}{l}\text { Discussão da situação da } \\
\text { pesquisa e da educação }\end{array}$ & - & & 3 & $10 \%$ & - & - \\
\hline Outros & - & & - & & 4 & $9 \%$ \\
\hline
\end{tabular}

Quadro 1.4 - Grupos temáticos para o estado da arte

\subsection{Delimitação do Tema da Pesquisa}

A quantidade de trabalhos de estado da arte para os temas "aprendizagem organizacional" e "aprendizagem organizacional nas pequenas empresas" indica sua importância atual, nacional e internacionalmente. A tendência de crescimento de trabalhos como teses, dissertações e apresentações de congressos, já observada e discutida na página 23, indica que o tema tende a continuar relevante academicamente. Já o "vulcão verde", que é a caracterização de processos de aprendizagem organizacional, tanto como teoria geral quanto aplicada às pequenas empresas, foi sinalizado como um dos maiores "vulcões ativos" da atualidade, segundo a analogia proposta por Easterby-Smith e Crossan (2000). Sendo assim, é importante a realização de esforços no sentido de preencher a lacuna de produção acadêmica brasileira que foi detectada com a aplicação da busca sistemática, conforme a descrição dos cinco "vulcões ativos" realizada na Seção 1.2.

Do ponto de vista metodológico também faltam pesquisas empíricas, principalmente aquelas baseadas em observações diretas. Há uma clara preponderância de artigos conceituais (aproximadamente $40 \%$ do total). As pesquisas empíricas geralmente são quantitativas e procuram estabelecer a correlação entre fatores facilitadores ou inibidores dos processos e 
subprocessos pesquisados, servindo-se de questionários padronizados. O número de pesquisas qualitativas, exploratórias, é extremamente pequeno. Entre os 25 artigos localizados no "vulcão verde" da paisagem geral internacional apenas 2 empregaram explicitamente uma metodologia qualitativa; entre os 8 artigos localizados no "vulcão verde" da aprendizagem organizacional no território das pequenas empresas apenas um tem natureza qualitativa. Nenhum dos artigos nacionais listados emprega esta metodologia.

Considerando o contexto nacional apresentado na Seção 1.1, seria interessante não só preencher a lacuna de conhecimento identificada durante a análise do estado da arte, mas também contribuir com pesquisas empíricas, qualitativas e exploratórias que aproximem as diferentes correntes teóricas internacionais do cotidiano brasileiro, principalmente no que se refere às aplicações para a gestão de pequenas empresas. O trabalho aqui apresentado se propõe a contribuir justamente nesta direção.

\subsection{Formulação do Problema da Pesquisa}

Embora a figura do empreendedor e o empreendedorismo venham sendo estudados há várias décadas, a pequena empresa foi tratada como uma "pequena grande empresa" até o final da década de 60 , sob a crença de que apenas as grandes organizações burocráticas teriam influência econômica e social. No início dos anos 80 alguns estudiosos chegaram a prever o fim das pequenas empresas, com a ênfase na produção em massa que implicaria a necessidade de crescer para sobreviver (JULIEN, 1997; TERENCE, 2008; CARVALHO, 2010).

Nos anos 90, entretanto, o tema das pequenas empresas ressurgiu, não só como tema importante no âmbito acadêmico, mas também como preocupação governamental, em decorrência das transformações organizacionais (como o enxugamento das estruturas organizacionais e redução dos níveis hierárquicos, por exemplo) e das transformações sociais e tecnológicas destas duas últimas décadas (como, por exemplo, a globalização, o aparecimento de empresas virtuais, o crescimento das redes de relacionamento e o desenvolvimento das tecnologias da informação). Um indício do crescente reconhecimento da importância das pequenas empresas é a consolidação de órgãos de estudo e apoio à pequena empresa, como a Academia de Empreendedorismo Francesa, a Small Business Administration (SBA) americana e o Serviço Brasileiro de Apoio à Pequena Empresa (SEBRAE) (JULIEN, 1997; TERENCE, 2008; CARVALHO, 2010). 
Ao trazer o tema da aprendizagem organizacional para o âmbito das pequenas empresas é preciso considerar que estas possuem características próprias de gestão e de processos, e estão sujeitas a mais incerteza e ambiguidade do que as grandes empresas. Essas características próprias (ou especificidades) das empresas menores afetam sua aprendizagem organizacional (TORRES, 2004).

As pequenas empresas possuem problemas de planejamento e organização (inclusive de programas de capacitação), geralmente trabalham com mão de obra menos especializada e operam com margens mais apertadas e número reduzido de funcionários (o que dificulta a implementação de programas de treinamento, por exemplo). Entretanto, também são menos burocratizadas, reagem mais rapidamente a novas situações, estão mais próximas de seus mercados e possuem maior facilidade de comunicação e transmissão de ideias. Além disso, seu tamanho permite o desenvolvimento de capacidades extremamente especializadas, para atender certos nichos extremamente sofisticados de mercado, o que estimula a inovação (GARCÍA-MORALES; LLORÉNS-MONTES; VERDÚ-JOVER, 2007).

Assim, o problema de pesquisa foi formulado: Como mapear a aprendizagem organizacional em relação às especificidades da pequena empresa?

\subsection{Declaração dos Objetivos da Pesquisa}

O principal objetivo da pesquisa é construir um mapa conceitual, informado pelas "Teorias de Aprendizagem Organizacional", que represente os processos de aprendizagem organizacional na realidade da pequena empresa.

O objetivo específico é compreender as especificidades de uma micro empresa de base tecnológica e sua relação com os processos de aprendizagem organizacional, oferecendo uma primeira verificação para complementar a teoria pesquisada.

\subsection{Pressupostos Epistemológicos e Estratégia de Pesquisa}

A ciência, nos moldes correntes definidos pela academia, avança a partir da obtenção de consenso e valida a criação de conhecimento a partir do crivo de "indivíduos competentes e desinteressados. (...) O objetivo da Ciência não é apenas adquirir informação, nem enunciar postulados indiscutíveis; sua meta é alcançar um consenso de opinião racional que abranja o 
mais vasto campo possível.” (ZIMAN, 1979, p. 24). A obtenção de consenso, entretanto, precisa ser construída a partir de uma linguagem comum e da aceitação dos pressupostos subjacentes aos raciocínios empregados, isto é, da utilização de um paradigma comum ao pesquisador e aos pares que validarão a pesquisa.

Os temas de estudo do presente trabalho possuem origem multidisciplinar, com contribuições de ciências hermenêuticas (interpretativas), como a Psicologia e a Sociologia, e já possuem, em sua concepção, alguns pressupostos definidos. O principal pressuposto no estudo de processos de aprendizagem é a intencionalidade, o envolvimento consciente do ator do processo, a discussão de significados e vivências (SAMPAIO, 2001). Ou seja, os processos estudados só serão perceptíveis a partir do momento em que seus atores os explicitarem. A necessidade de consciência, intencionalidade e explicitação dos processos pelos atores lhes confere um caráter intrinsecamente individual, já que dificilmente duas pessoas executarão os processos de aprendizagem pessoal e interação social para disseminação do conhecimento exatamente da mesma forma. É necessário compreender fenômenos subjetivos e não lineares (não sujeitos a relações de causa e efeito), pois estes serão decorrentes da intenção do objeto. Dessa forma, é preciso adotar uma metodologia e premissas epistemológicas diferentes daquelas normalmente esperadas para um trabalho desenvolvido no campo da Engenharia de Produção ou da Administração. Coerentemente com o tema pesquisado, esse trabalho também será multidisciplinar: os métodos e a estratégia aplicados à pesquisa serão "emprestados" da área das ciências sociais.

Assim, Sztompka (1991 apud PETTIGREW, 1992) define algumas premissas sobre a realidade social que são relevantes no estudo de processos com alto envolvimento de pessoas (como é o caso dos processos de aprendizagem) e que tornam coerente a abordagem subjetiva proposta por Burrell e Morgan (1979):

i) A realidade social não é um estado estável, e sim dinâmico (ela ocorre, não existe). Portanto, não há sentido na procura por regularidades subjacentes, ou relações causais (o conhecimento é construído de forma anti-positivista).

ii) A vida social é um processo de emergência estrutural a partir de ações: a força que move o processo é justamente a tensão entre estrutura e ação. Portanto, seu entendimento advém do envolvimento do investigador no cotidiano do sujeito investigado, da referência do investigador como participante na ação (a metodologia empregada é ideográfica, isto é, "participativa").

iii) No contexto em que a estrutura emerge esta tensão gera uma dualidade, as estruturas influenciam os atores e são por eles influenciadas, e vice-versa (as 
estruturas dão forma e são formadas e os atores produzem e são produzidos). Portanto, não é possível aceitar uma única estrutura "real" e universal, à medida em que os fenômenos dependem da forma como são descritos e entendidos. Isso significa uma construção ontológica nominalista, isto é, admite-se que a realidade varia de acordo com a forma como é descrita.

iv) o intercâmbio de ação e estrutura varia no tempo e é cumulativo - o estudo de processos não procura descrever a sequência destas interações no tempo ou relatar a história, mas sim identificar padrões dentro da imprevisibilidade e da variabilidade da realidade social. Esta última característica relaciona-se às demais, ou seja, admite-se a importância da participação do pesquisador e da forma como os fenômenos são entendidos e descritos. Além disso, admite-se que não haja uma relação constante de causa e consequência ou leis universais, isto é, os fenômenos podem ser descritos de formas diferentes por observadores diferentes, em contextos diferentes e em momentos diferentes. Isso pressupõe a importância da participação humana, o que significa a adoção de uma postura voluntarista.

A estratégia de pesquisa, portanto, precisa ser coerente com os objetivos propostos e o paradigma adotado. Dessa forma, foi escolhido um estudo de caso instrumental, delimitado da forma proposta por Stake $(1995$; 2008): o caso escolhido apresenta um contexto e um ambiente natural propícios para que os fenômenos se manifestem (daí a escolha de uma empresa de base tecnológica), é pequena, permitindo a aproximação entre a pesquisadora e os fenômenos de aprendizagem, e garantiu amplo acesso à pesquisa, ampliando oportunidades de observação e construção de um raciocínio indutivo, desencadeado a partir do reconhecimento de características particulares.

Quanto ao estudo de um único caso, o próprio método de estudo de caso qualitativo proposto por Stake oferece essa possibilidade na forma de um estudo de caso instrumental, que consiste numa vivência mais aprofundada de um único local (caso) como ponto de partida para o entendimento dos fenômenos estudados (STAKE, 1995). 


\subsection{Relevância da Pesquisa}

A grande disparidade encontrada entre a necessidade de agregação de valor e a situação das pequenas empresas no Brasil torna o tema especialmente importante para os estudos sobre pequenas empresas (ver a Seção 1.1).

Apesar de constituir, como conjunto, uma parcela importante da produção econômica e absorver parcela significativa da mão de obra ativa do país, funcionando inclusive como uma forma de reduzir impactos de crises econômicas, a pequena empresa, individualmente, é tradicionalmente o elo mais frágil da cadeia econômica (CARVALHO, 2010), estando sujeita a mais incertezas e mudanças mais bruscas, o que é traduzido por uma taxa de mortalidade muito superior à das médias e grandes empresas (ROCHA, 2008). O conhecimento aprofundado dos processos de aprendizagem organizacional pode oferecer ferramentas para que empreendedores e dirigentes de micro e pequenas empresas lidem melhor com a incerteza e a ambiguidade de seu ambiente, mantendo vantagens competitivas (KONTOGHIORGHES; AWBRE; FEURIG, 2005; TOMAÉL; ALCARÁ; DI CHIARA, 2005; GARCÍA-MORALES; LLORENS-MONTES; VERDÚ-JOVER, 2006).

Além disso, as implicações da aprendizagem organizacional para inovação podem promover a revisão de algumas políticas públicas, oferecendo conhecimento e informações úteis para as entidades de fomento e apoio a empreendedores e dirigentes de micro e pequenas empresas.

No âmbito acadêmico, pode-se afirmar que a delimitação do tema é coerente com a relevância atual do assunto e atende às necessidades de desenvolvimento da teoria explorada, dadas as lacunas existentes, introduzindo um tema e uma metodologia inéditos em publicações brasileiras (ver a Seção 1.3).

\subsection{Motivação para a pesquisa}

Esta dissertação reflete o interesse da pesquisadora (que já atuou como administradora de uma pequena empresa e como consultora de gestão e estratégia para pequenas e médias empresas) em colaborar na construção de uma teoria organizacional voltada à pequena empresa, que é o objetivo do Grupo de Estudos Organizacionais da Pequena Empresa (GEOPE), do qual faz parte. 


\subsection{Estrutura do Texto}

O arcabouço teórico que norteará este estudo será então derivado da imbricação de dois temas principais, a aprendizagem organizacional e as especificidades das pequenas empresas, e será construído em três níveis: i) a inserção do tema e do problema de pesquisa na fronteira do conhecimento relativo ao assunto; ii) a construção de uma base teórica baseada na revisão bibliográfica e iii) a formulação de um "mapa conceitual", entendido como um esquema de interpretação dos conceitos desenvolvidos, que orientará a pesquisadora em sua pesquisa de campo.

Depois disso, será apresentada a abordagem metodológica e a descrição dos protocolos adotados, seguida da análise e discussão dos resultados. A partir da análise efetuada o "mapa conceitual" será reavaliado e a conclusão (resultado) do trabalho será apresentada como uma proposta de mapa conceitual embasado e verificado pela experiência em campo.

Assim, este trabalho está organizado em sete capítulos: este capítulo inicial contextualiza o problema de pesquisa, introduz os temas a serem abordados e define a fronteira do conhecimento para os mesmos, além de apresentar a estratégia e as abordagens epistemológicas da pesquisa. Os capítulos 2 e 4 trazem a revisão bibliográfica dos dois grandes temas abordados, a aprendizagem organizacional e as especificidades das pequenas empresas, particularmente as de base tecnológica, enquanto que o capítulo 3 explicita a construção do mapa conceitual. O capítulo 5 traz as considerações metodológicas que definirão a condução da pesquisa em campo, incluindo a proposta do mapa conceitual a ser verificado. A apresentação e análise dos dados coletados são o conteúdo do capítulo 6 . A reformulação do modelo e as conclusões da pesquisa estão no último capítulo, o capítulo 7.

Adicionalmente, o trabalho também contém três anexos, que apresentam os resultados de cada uma das buscas sistemáticas aplicadas aos temas pesquisados, no cenário nacional e internacional, com uma breve descrição dos artigos selecionados e listados na Seção 1.2. O diário de campo da pesquisa e as transcrições das entrevistas efetuadas, em sua íntegra, não constituem parte do texto, mas estarão à disposição da banca em documento separado. 


\section{Aprendizagem organizacional: conceitos relevantes}

Esse capítulo descreve o arcabouço teórico da pesquisa, apresentando os principais autores e as principais correntes de pensamento detectadas ao final do processo de busca sistemática executado para o tema principal desse trabalho, a aprendizagem organizacional.

\subsection{Definições e Obras Seminais}

Inseridas em um ambiente competitivo, complexo e mutável, as organizações precisam garantir sua posição competitiva para assegurar sua sobrevivência. Assim, elas desenvolvem competências ou capacidades organizacionais para a definição e a solução de problemas que mantenham ou melhorem seu desempenho e fomentem o desenvolvimento de alternativas idiossincráticas de crescimento estratégico. Se estas competências forem raras, valiosas, não substituíveis e imitáveis apenas imperfeitamente, elas determinarão a vantagem competitiva de uma empresa. O desenvolvimento de tais competências, por sua vez, dependerá da capacidade da empresa em gerar, trocar e utilizar as informações necessárias para o atingimento dos resultados organizacionais desejados e alterar seu comportamento de acordo com os problemas enfrentados, as oportunidades percebidas (ou criadas) e o comportamento das demais organizações presentes no ambiente, ou seja, da capacidade de aprender da empresa (LADO; WILSON, 1994; NEVIS; DIBELLA; GOULD, 1995; LEI; HITT; BETTIS, 1996). A habilidade de aprender é uma fonte importante, se não única, de vantagem competitiva (LEVINTHAL; MARCH, 1993).

Embora pareça haver uma confortável concordância sobre a importância da aprendizagem organizacional, um primeiro contato com a literatura, entretanto, parece demonstrar pouco consenso em geral, a começar pela aparente ausência de uma definição comum. Argyris (1977) define a aprendizagem organizacional não só como a detecção e a correção de erros, mas também como a capacidade de saber quando não se é capaz de identificar e corrigir erros. Levitt e March (1988) a definem como a codificação de inferências históricas em rotinas para a obtenção de um resultado almejado. Huber (1991) a define como um processo intencional direcionado à melhora da eficácia através do processamento de informações com o objetivo de alterar o conjunto de comportamentos potenciais da organização. Pisano (1994) a define como um processo de solução de problemas desencadeado por lacunas entre o desempenho atual e o desempenho potencial de uma organização através da integração entre o conhecimento existente e novos conhecimentos. 
Huber (1991) e Barnett e Hansen (1996) a definem como o resultado dos ajustes cotidianos das rotinas organizacionais efetuados em resposta a pressões competitivas do ambiente através de um processo de pesquisa e tomada de decisão. Já Lam (2000) ressalta a natureza social do processo de aprendizado. Em meio a uma provável miríade de definições, o último exemplo será o de March (1991), que define o processo de aprendizagem organizacional como a troca entre os conhecimentos da organização (ou seu "código") e os conhecimentos individuais de seus membros, realizada durante o processo de socialização.

Em meio a esta aparente heterogeneidade, mais uma vez uma abordagem sistemática foi capaz de evidenciar algumas teorias seminais, tão importantes para o desenvolvimento da teoria de aprendizagem organizacional que se mantiveram relevantes e influentes até hoje. Isso foi feito através da observação das referências utilizadas nos artigos selecionados para o estado da arte. Apesar de parecerem bastante diversos e possuírem abordagens até mesmo conflitantes, todos se baseiam nos mesmos cinco autores mais citados, e em trabalhos que foram lançados ainda na década de 90.

O Quadro 2.1, na próxima página, mostra quais artigos foram citados em cada um dos 37 artigos estudados para o estado da arte, ou se algum outro artigo do mesmo autor (com a mesma temática, escrito em época próxima) foi citado. Nele é possível perceber que alguns autores, tais como James March ou Ikujiro Nonaka, propuseram correntes de pensamento que ainda continuam sendo exploradas e desenvolvidas, enquanto outros, como George Huber ou Peter Senge, publicaram artigos ou modelos de bastante impacto, mas que não foram desenvolvidos posteriormente.

Assim, da mesma forma que a abordagem sistemática permitiu delimitar cinco "vulcões ativos" na paisagem bibliográfica do estado da arte do tema, ela também permitiu identificar cinco grandes "árvores" na paisagem heterogênea, composta por muitos arbustos baixos, que se descortina quando nos aproximamos do "vulcão verde". As "cinco árvores" seriam: o modelo de subprocessos de Huber (1991) e o modelo SECI de Nonaka (1991), que ainda são os mais empregados para explicar os subprocessos da aprendizagem; o modelo de laço simples ("single loop") e de laço duplo ("double loop") de Argyris (1977), que tem sido usado para caracterizar os diferentes níveis de aprendizado organizacional há mais de três décadas (o livro de Argyris e Schön (1996) é um dos cinco trabalhos mais citados para caracterizar aprendizagem organizacional). Já o modelo de exploração ("exploration") x aprofundamento ("exploitation") de March (1991) é o mais utilizado para explicar os efeitos da aprendizagem sobre as organizações, enquanto que o modelo das organizações de 
aprendizagem de Senge (1990) é o modelo ideal de organização mais popular para ilustrar o emprego da teoria.

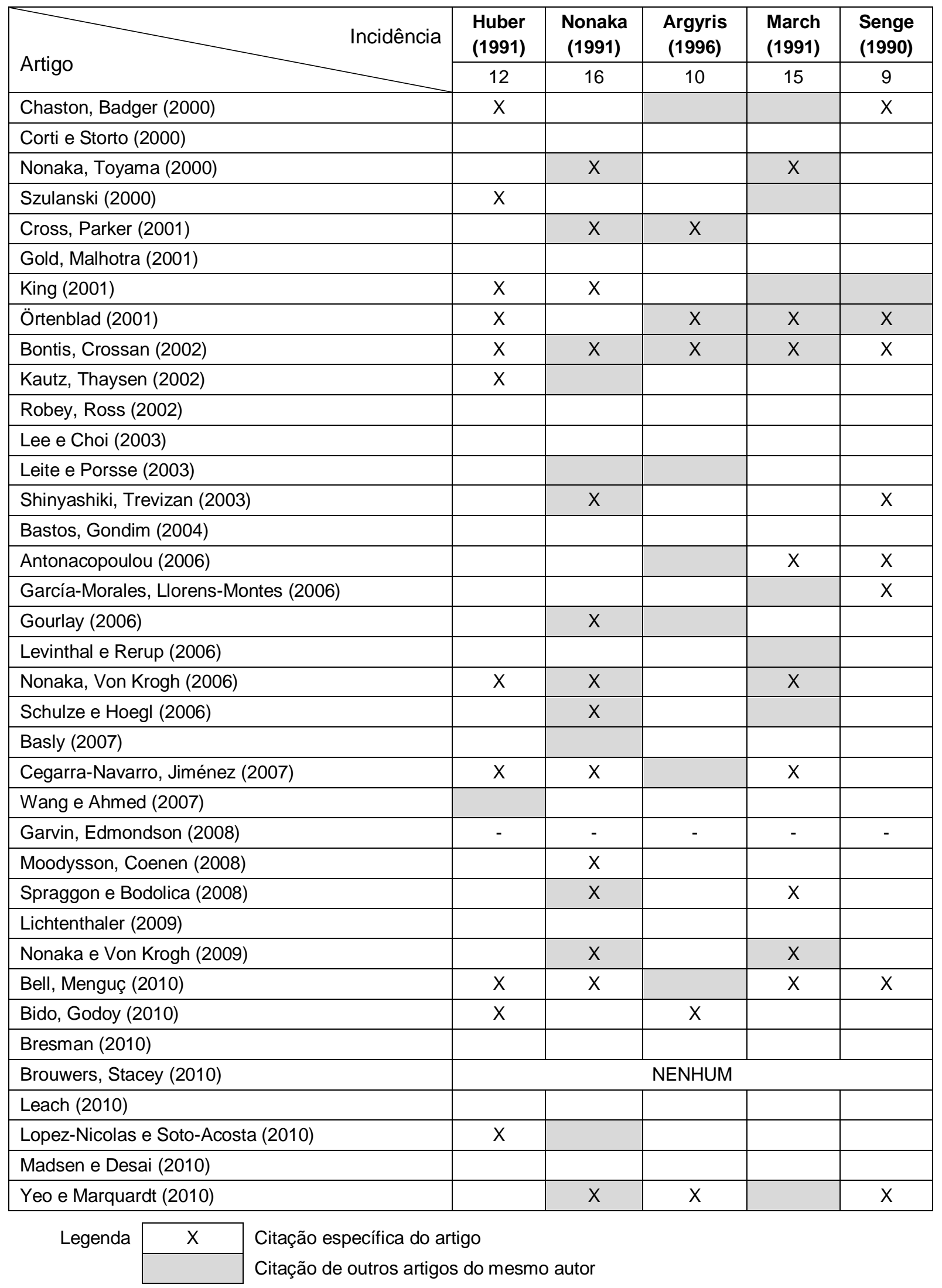

Quadro 2.1: Artigos e autores seminais na descrição dos processos de A. O. 
2.2. Os subprocessos da Aprendizagem Organizacional baseados nas teorias de Huber e Nonaka

Sendo um processo, a aprendizagem organizacional pode ser subdividida em quatro sub-processos interligados que têm como resultado final o aumento do nível de conhecimento da organização (HUBER, 1991).

O primeiro sub-processo é o de aquisição de conhecimento, ou o processo de obtenção de informações. As organizações já são criadas com um nível de conhecimento inicial (a respeito do ambiente em que são criadas e dos processos a serem executados para que cumpram a sua intenção inicial), a chamada aprendizagem congênita, e adicionam informações de outras organizações ou entidades (aprendizagem através dos outros), através de contratações, fusões, aquisições e parcerias (aprendizagem por enxerto), através da varredura do seu ambiente, da procura focada por soluções ou oportunidades e do monitoramento de seu desempenho (aprendizagem por pesquisa) e, principalmente, através da avaliação e interpretação de decisões, sucessos e fracassos passados (aprendizagem por experiência) (HUBER, 1991).

Qualquer que seja o método empregado para a obtenção de informações, a multiplicidade de fontes é um fator crítico para o sucesso do aprendizado. As organizações precisam processar não apenas as informações explícitas, formalizadas (o "know-what" ou "hard information") como também as informações tácitas, crenças, comportamentos e heurísticas (o "know-how" ou "soft information") (HUBER, 1991; MARCH, 1991; NONAKA, 1991; BROWN; DUGUID, 1998).

O segundo sub-processo é o de distribuição da informação, ou o processo de compartilhamento das informações de diferentes fontes ao longo da organização, gerando novas informações ou nova compreensão. Esse é o processo que disponibiliza a informação dentro da organização. Três fatores são críticos para o seu sucesso: a facilidade de recuperação das informações coletadas, o número de membros da organização que possuem acesso às informações e a conversão de conhecimento tácito em explícito (ou as etapas de socialização (socialization $-S$ ) e externalização (externalization $-E$ ) descritas por Nonaka (1991) em sua “espiral do conhecimento") (HUBER, 1991).

O terceiro sub-processo é o de interpretação da informação, ou o processo através do qual as informações distribuídas recebem uma ou mais interpretações que são comumente entendidas pelos membros. Esse é o processo que gera novos conhecimentos através da execução das etapas de combinação (combination $-C$ ) e internalização (internalization $-I$ ) 
descritas por Nonaka (1991) em sua "espiral do conhecimento". Ele também promove o descarte de informações obsoletas ou incorretas (desaprendizagem). Três fatores são críticos para o seu sucesso: os mapas cognitivos ou quadros de referência presentes na organização, a eficiência no compartilhamento de informações e o gerenciamento da sobrecarga de informações. Os mapas cognitivos nortearão a interpretação das informações, permitindo a elaboração de significados comuns. A eficiência no compartilhamento de informações depende da velocidade, da abrangência e do tempo de resposta (feedback) da comunicação. Por fim, o gerenciamento da sobrecarga de informações é fundamental para que novas informações sejam absorvidas, já que a quantidade de informações disponível sempre tende a ser maior do que a capacidade de processamento do receptor (HUBER, 1991).

A interpretação (ou internalização) é o processo que converte conhecimento individual em conhecimento coletivo (ou organizacional). As organizações precisam transferir conhecimentos tácitos e explícitos não só entre os seus membros, mas também transformar conhecimentos individuais (competências, crenças, comportamentos) em conhecimento organizacional (modelos, regras, procedimentos, convenções, estratégias, tecnologias, quadros de referência, paradigmas, códigos, cultura). Para que este processo seja bem-sucedido é preciso que as informações sejam processadas de forma a gerar múltiplas interpretações (diversidade de repertório para a organização) e, ao mesmo tempo, que os membros da organização possuam uma compreensão comum das interpretações geradas (disseminação do conhecimento). Como o aumento do número de interpretações reduz a probabilidade de que todos os membros da organização as compreendam na íntegra de forma uniforme, o equilíbrio entre a necessidade de diversidade e de disseminação é um fator crítico para o sucesso do aprendizado (LEVITT; MARCH, 1988; HUBER, 1991; NONAKA, 1991).

O quarto e último sub-processo é o de memória organizacional, ou o processo através do qual o conhecimento é armazenado para uso futuro. Os sub-processos de armazenamento e recuperação da informação são os centrais da memória organizacional. É preciso considerar como estes processam as informações "soft" e "hard" e também as informações não rotineiras e depois disponibilizam todas as informações obtidas para decisões futuras. Estes subprocessos são afetados primariamente pelos seguintes fatores:

i) a previsão de necessidade futura da informação;

ii) o compromisso dos membros da organização com os sub-processos;

iii) a facilidade de acesso e utilização dos canais e mecanismos disponíveis.

Isso significa que há quatro fatores críticos para a implementação bem-sucedida deste processo: 
i) a gestão dos atritos entre os membros da organização,

ii) a distribuição e interpretação da informação,

iii) as normas e métodos empregados para armazenar a informação e

iv) os métodos empregados para localizar e recuperar a informação (HUBER, 1991).

\subsection{Os resultados da Aprendizagem Organizacional baseados nas teorias de March e} Argyris

Enquanto que Huber e Nonaka preocuparam-se em modelar e descrever detalhadamente o processo de aprendizagem organizacional, March e Argyris preocuparam-se em descrever suas características e seus efeitos na organização. Assim, uma possível síntese das teorias poderia responder, de forma mais abrangente, não só como a aprendizagem organizacional acontece, mas como seus efeitos podem ser observados.

\subsubsection{Aprendizagem Generativa e Aprendizagem Adaptativa}

Considerando-se os processos e as aplicações do aprendizado, é possível concluir que ele ocorre, necessariamente, em todas as empresas capazes de sobreviver em seu ambiente. Com efeito, Nevis e Dibella (1995, p.73) concluíram que "todas as organizações possuem sistemas que apóiam o aprendizado" e Brown e Duguid (1998) postulam que todas as empresas que sobrevivem no ambiente competitivo são organizações de aprendizagem, à medida em que sua habilidade de obter resultados superiores aos do mercado reside na geração contínua e na síntese do conhecimento coletivo que constitui sua "competência essencial".

Por outro lado, "se a proficiência em uma atividade em particular é crítica para obtenção de vantagem competitiva, e tal proficiência pode ser melhorada com o tempo, então o aprendizado deve ter um papel central na obtenção de vantagem competitiva entre empresas" (PISANO, 1994, p.86). Mas, se todas as organizações aprendem, o que então torna o aprendizado uma fonte de vantagem competitiva?

Para responder essa pergunta, vamos analisar primeiro o que diferentes empresas aprendem, que as leva a diferentes resultados. As organizações utilizam seus conhecimentos essencialmente para dois objetivos: a sobrevivência e a obtenção de melhor posicionamento 
competitivo. A sobrevivência da empresa está geralmente associada à melhora de desempenho, correção de erros e adaptação ao ambiente, enquanto que o posicionamento competitivo está geralmente associado à variabilidade de comportamentos e soluções, ou à adaptabilidade (capacidade de inovação) da empresa (MARCH, 1991; LEVINTHAL; MARCH, 1993).

A aprendizagem voltada para a melhora de desempenho é denominada adaptativa por Lei, Hitt e Bettis (1996), de especialização ou aprofundamento (exploitation) por March (1991) e corretiva (ou de laço único) por Argyris (1977). Suas características principais são a dependência do histórico e das experiências da organização (path-dependency) e dos seus mecanismos de feedback, a geração de mudanças incrementais (o processo é geralmente iterativo, precisando de várias repetições para alcançar algum resultado), a ligação com a solução de problemas (reativa, portanto) e a proximidade temporal e espacial com os problemas e metas abordados, fazendo com que o retorno seja mais rápido e mais facilmente mensurável (MARCH, 1991).

Essa aprendizagem é geralmente limitada a um processo ou rotina único e geralmente ocorre em pontos isolados da organização (em uma divisão ou uma equipe, por exemplo) e implica no aprofundamento de conhecimentos e no desenvolvimento de competências já préexistentes, aumentando o conhecimento sobre um único assunto ou problema. Sua ação ocorre sobre um ambiente simplificado e decomposto em partes facilmente analisáveis (artificial, portanto, criado especificamente para contornar as limitações humanas frente à complexidade e da quantidade de informações de seu ambiente) (LEVITT; MARCH, 1988; MARCH, 1991; MCGILL; SLOCUM; LEI, 1992; LEVINTHAL; MARCH, 1993; PISANO, 1994).

Do ponto de vista processual, a aprendizagem adaptativa coleta informações através da aprendizagem por experiência (através de experimentos organizacionais, auto-avaliação e curvas de aprendizado) e da aprendizagem através dos outros (gerando a homogeneidade organizacional abordada pela Teoria Institucional) e é fortemente dependente da aprendizagem endógena, que consiste na base sobre a qual o conhecimento será erguido (HUBER, 1991; LEVINTHAL; MARCH, 1993).

A distribuição da informação é limitada (resumindo-se algumas vezes ao grupo de trabalho ou à divisão envolvida) e a interpretação é uniforme e pouco variada, obedecendo a um padrão mais rígido de causa e consequência. A memória organizacional geralmente é um processo simplificado (produção de manuais ou criação de processos, por exemplo) e, portanto, mais facilmente implementável (LEVITT; MARCH, 1988; HUBER, 1991; MARCH, 1991; LEVINTHAL; MARCH, 1993). 
A aprendizagem voltada para a melhora de posicionamento competitivo (ou inovação) é denominada generativa por Lei, Hitt e Bettis (1996), de exploração (exploration) por March (1991) e generativa (ou de laço duplo) por Argyris (1977). Suas características principais são a pesquisa, o aumento de variabilidade, a geração de mudanças abruptas, a ligação com o aumento de repertório (proativa, portanto) e a distância temporal e espacial com as oportunidades e metas abordadas, fazendo com que o retorno seja lento, disperso e de difícil mensuração (MARCH, 1991).

Essa aprendizagem geralmente ocorre pela integração de competências e conhecimentos distintos, presentes em áreas e níveis diferentes da organização, e implica a criação de novas competências, rotinas, tecnologias ou produtos. Sua ação ocorre justamente na integração de ambientes simplificados e decompostos, abordando a complexidade presente no ambiente real em que a organização está inserida (LEVITT; MARCH, 1988; MARCH, 1991; MCGILL; SLOCUM; LEI, 1992; LEVINTHAL; MARCH, 1993; PISANO, 1994).

Do ponto de vista processual, a aprendizagem generativa coleta informações através da pesquisa, da experimentação e da valorização da aprendizagem não-intencional e emprega a aprendizagem por enxerto e por pesquisa de maneira rotineira. A aprendizagem endógena tem menor impacto, já que serve apenas como base sobre a qual o conhecimento será expandido. A distribuição da informação deve ser abrangente, em larga escala (preferencialmente englobando toda a organização, em todos os seus níveis) e há uma procura constante por novas interpretações, muitas vezes assíncronas e não lineares. A memória organizacional é um processo complexo, de difícil implementação, por causa da quantidade e complexidade de informações geradas a serem armazenadas e disponibilizadas (HUBER, 1991; MARCH, 1991).

Essa dificuldade processual faz com que haja um limiar para o desencadeamento da aprendizagem generativa. Segundo as teorias de racionalidade limitada na tomada de decisões, as escolhas entre aprendizagem generativa e aprendizagem adaptativa dependem da relação entre a meta definida e as alternativas disponíveis. Se a alternativa estiver acima e próxima à meta, a aprendizagem generativa é inibida. Por outro lado, se a alternativa estiver abaixo da meta, a aprendizagem generativa é estimulada (LEVINTHAL; MARCH, 1993).

Além disso, a aprendizagem generativa depende das condições do ambiente de aprendizado da organização. Estudando o desenvolvimento de novos produtos e processos na indústria farmacêutica, Pisano (1994, p.86) ressaltou que "o estado de conhecimento anterior sobre a tecnologia do processo determina as estratégias apropriadas para obtenção do feedback necessário ao aprendizado". Quando não há conhecimento anterior há necessidade 
de feedbacks de alta fidelidade sobre o próprio ambiente de produção, estimulando o aprendizado adaptativo. Por outro lado, quando há modelos teóricos confiáveis e heurísticas, podem ser utilizados experimentos em laboratório, simulação e outras formas de "aprender antes de fazer" (ou aprendizado generativo).

Assim, a resposta à pergunta inicial, " se todas as organizações aprendem, o que então torna o aprendizado uma fonte de vantagem competitiva?" está justamente no equilíbrio entre os recursos e a prioridade conferidos ao aprendizado generativo e ao aprendizado adaptativo pelas organizações, traduzidos em escolhas explícitas (investimentos e estratégias competitivas) e implícitas (procedimentos, regras e práticas, definição de metas e sistema de recompensa) (MARCH, 1991).

A sobrevivência das organizações depende de atingir o equilíbrio entre a exploração de novas possibilidades (aprendizado generativo) e o aprofundamento dos conhecimentos já adquiridos (aprendizado adaptativo) para o aprendizado organizacional. Sistemas adaptativos que só perseguem a inovação não têm tempo para implementar os ganhos derivados desta (como a redução de custos ou do tempo de produção, por exemplo) e acabam por apresentar um desempenho irregular e aleatório. Por outro lado, sistemas que apenas aprofundam os próprios conhecimentos tendem a atingir um equilíbrio estável em níveis sub-ótimos de desempenho. A dificuldade na escolha reside no fato de que os retornos entre as duas práticas variam não só em termos do valor do retorno que oferecem, mas também em termos de tempo de retorno e da distribuição do retorno dentro e fora da organização (MARCH, 1991).

Por estar relacionada à pesquisa, à variabilidade, à tomada de risco, à experimentação, à flexibilidade, à descoberta e à inovação, a aprendizagem generativa produz retornos mais incertos, mais remotos no tempo e organizacionalmente mais distantes do lócus da ação e da adaptação. A distribuição de consequências no tempo e no espaço afeta as lições aprendidas de maneira não linear ou causal. Inversamente, a aprendizagem adaptativa está associada ao refinamento, à escolha, à produção, à eficiência, à seleção, à implementação e à execução, gerando certeza, velocidade, proximidade do lócus da ação e clareza no feedback (MARCH, 1991).

Por causa das diferenças entre ambas, os processos adaptativos tendem a desenvolver a aprendizagem adaptativa mais rapidamente do que a aprendizagem generativa, já que os feedbacks rápidos sobre o retorno potencial da aprendizagem adaptativa acabam por criar uma dependência com a trajetória. Assim, a competência adquirida em uma atividade pode inibir a exploração de atividades superiores, tornado os processos adaptativos potencialmente autodestrutivos (MARCH, 1991). 
Por outro lado, a experiência organizacional (aprendizado adaptativo) gera informações que são incorporadas ao conhecimento da organização, aumentando seu repertório. $\mathrm{O}$ aumento de repertório estimulará os processos de pesquisa e inovação futuros. Assim, quanto maior for a base de conhecimento da empresa, melhores as chances de execução de pesquisas e maior a possibilidade de inovação. Nesse caso, o "aprendizado adaptativo" não se opõe ao "aprendizado generativo", mas sim o estimula (PISANO, 1994).

\subsubsection{Desempenho e Variabilidade}

Suponha que o resultado obtido por uma organização em determinado momento seja representado por uma curva de distribuição de probabilidades cuja ordenada seja o valor atribuído a esse desempenho (definido como uma função entre os retornos potenciais de uma atividade e a competência atual da organização em desempenhá-la) e a abscissa represente a distribuição da ocorrência dos diferentes desempenhos (variabilidade), como representado na Figura 2.1:

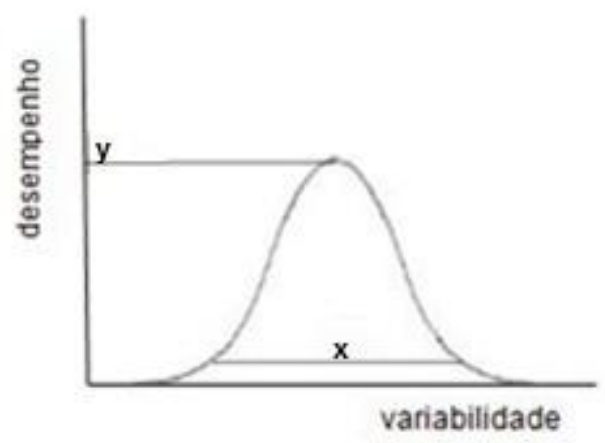

Figura 2.1 - Desempenho x Variabilidade Fonte: adaptada de March (1991)

A aprendizagem adaptativa aumenta a confiabilidade (repetibilidade) dos processos, o que geralmente está relacionado à qualidade dos produtos ou à curva de aprendizagem dos processos (e à redução de custos). Isso representa o aumento do valor do desempenho ( $\mathrm{x}^{\prime}>$ $\mathrm{x}$ ), mas reduz a variabilidade (y'<y), como representado na Figura 2.2: 


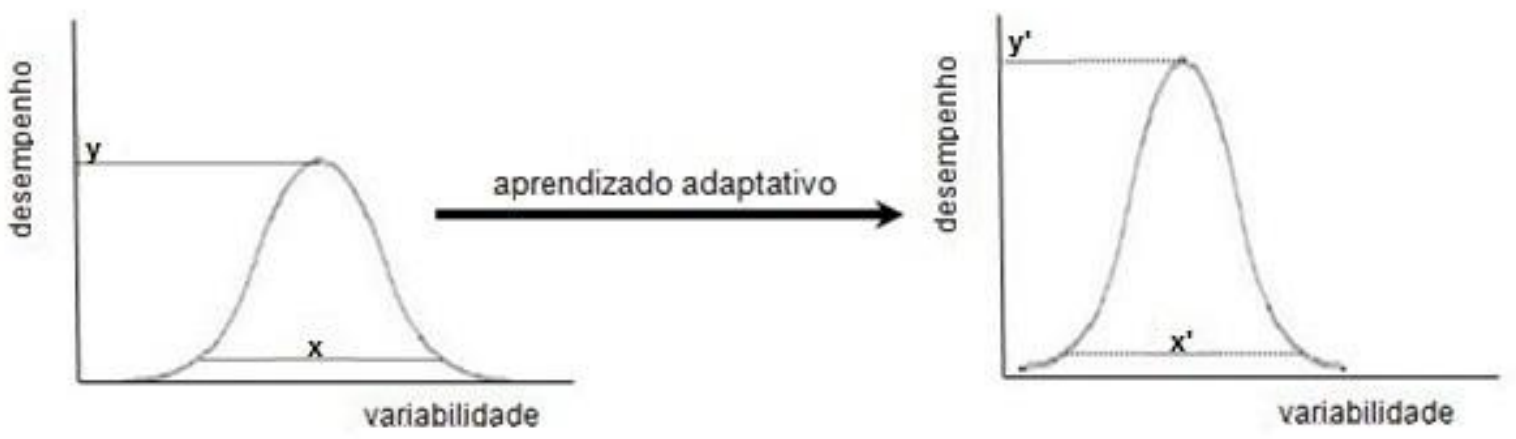

Figura 2.2 - Efeito da aprendizagem adaptativa

Fonte: adaptada de March (1991)

A aprendizagem generativa reduz a previsibilidade (repetibilidade) dos processos, já que os retornos são deslocados no espaço e no tempo e, portanto, menos sujeitos a processos de correção e feedback. Isso representa o aumento da variabilidade ( $\left.y^{\prime}>\mathrm{y}\right)$, mas reduz o desempenho $\left(\mathrm{x}^{\prime}<\mathrm{x}\right)$, como representado na Figura 2.3:
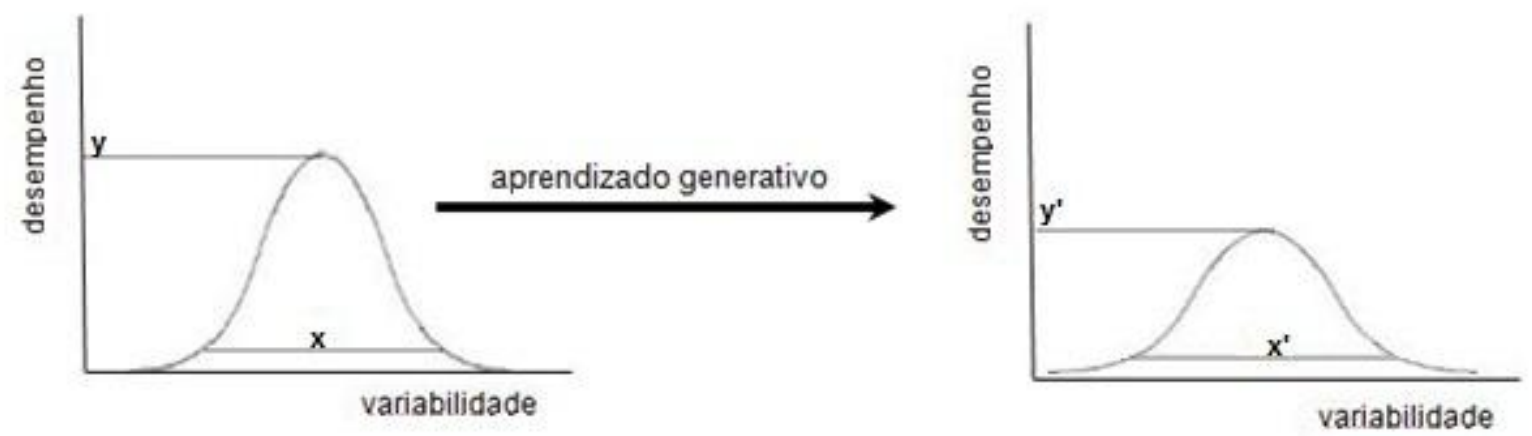

Figura 2.3 - Efeito da aprendizagem generativa

Fonte: adaptada de March (1991)

Podemos definir como conhecimento um vetor composto por um valor médio de desempenho e um valor de variabilidade associado ao número de competidores. $\mathrm{O}$ conhecimento afeta a posição competitiva das organizações: a variabilidade aumenta as chances de alcançar as primeiras posições, ao passo que o desempenho diminui as chances de ficar em último (MARCH, 1991).

Quanto menor o número de competidores, maior a importância do valor do desempenho. Quanto maior o número de competidores, maior a importância do valor da variabilidade. Do ponto de vista estratégico, a melhora de desempenho por si só não implica 
em vantagem competitiva, pois reduz a variabilidade. Pelo contrário, o preço da confiabilidade é a redução da chance de obter primazia entre os competidores. Entretanto, num ambiente competitivo, a melhora no desempenho reduz as chances de que a organização fique entre os últimos colocados, garantindo a sua sobrevivência. A formação da estratégia organizacional, dessa forma, reflete como o equilíbrio entre desempenho e variabilidade é obtido (MARCH, 1991).

Os conceitos de desempenho e variabilidade se relacionam também aos conceitos de adaptação e adaptabilidade de Barnett e Hansen (1996): enquanto o desempenho melhora a capacidade sobrevivência da empresa a curto prazo (ou enquanto as condições presentes do ambiente perdurarem) - o que os autores denominam adaptação, ou a capacidade de implementar pequenas mudanças - a variabilidade cria condições para que as empresas continuem em condições de competir depois que o ambiente atual mudar, ou seja, a longo prazo - o que os autores denominam adaptabilidade, ou a capacidade de implementar mudanças radicais. Considerando-se a trajetória de longo prazo de uma organização à luz da teoria evolucionária, é inevitável que organizações bem adaptadas por períodos longos (ou seja, de alto desempenho) enfrentem em algum momento uma ruptura que demande uma capacidade de mudança muito maior do que a incremental (ou seja, de alta variabilidade). As empresas que possuem essa capacidade de "lidar com mudanças evolucionárias e revolucionárias" (TUSHMAN; O’REILLY III, 1996, p. 13) são denominadas ambidestras.

\subsection{As Organizações de Aprendizagem e o Modelo de Senge}

Nos anos 90 alguns teóricos com foco mais prescritivo (muitos deles consultores) cunharam o termo "organizações de aprendizagem" para definir as características e identificar e mensurar a incidência de processos inovadores nas organizações que conseguem equilibrar aprendizado adaptativo e aprendizado generativo, gerando as competências "raras, valiosas, não substituíveis e imitáveis apenas imperfeitamente" mencionadas na introdução do capítulo (LADO; WILSON, 1994, p. 699; LOIOLA; BASTOS, 2003).

Mas foi Senge (1990) que definiu o modelo prescritivo mais citado até o momento ao definir as organizações de aprendizagem como "organizações que estão continuamente expandindo sua capacidade de criar o futuro" e elencar cinco disciplinas que seriam as bases da formação das organizações de aprendizagem: domínio pessoal, modelos mentais, objetivo 
comum, aprendizado em grupo e raciocínio sistêmico. Essas disciplinas serão melhor exploradas no Capítulo 3, durante a elaboração do mapa conceitual. 


\section{Proposição de um Mapa Conceitual sobre Aprendizagem Organizacional}

Esse capítulo explica como o mapa conceitual inicial foi formulado, a partir da síntese do arcabouço teórico descrito no capítulo 2. Dois construtos serão desenvolvidos a partir da interpretação da própria pesquisadora em relação aos conceitos expostos no capítulo anterior, o de aprendizagem vertical e o de aprendizagem horizontal.

\subsection{Aprendizagem como um Vetor}

Toda organização possui um código organizacional, que é a somatória de todos os seus procedimentos, normas, regras, formas, linguagem e crenças. Esse código é transmitido às pessoas que fazem parte da organização através de instrução, doutrinação e exemplificação (MARCH, 1991). Por outro lado, os indivíduos que interagem dentro da organização causam alterações em seu código, que se adapta aos procedimentos, normas, regras, formas, linguagem e crenças individuais). Essas trocas entre organização e indivíduo acontecem num contexto competitivo em que ambos (organização e indivíduo) estão lutando por posições relativas em seu ambiente, o que implica a busca de soluções de curto e longo prazo. Dessa forma há uma troca constante, em dois níveis: entre o indivíduo e a organização e entre resultados de curto e longo prazo (MARCH, 1991). Assim, para essa proposição, a aprendizagem organizacional será considerada como uma sequência de alterações do código da organização.

Do ponto de vista processual, a aprendizagem organizacional pode ser considerada como uma sequência de alterações do código da organização resultantes da ocorrência de vários subprocessos (ver Seção 2.1), em momentos e locais distintos da empresa. Nonaka (1991) descreve o modelo da "espiral do conhecimento", com movimentos que ocorrem em nível individual, resultado direto de interações pessoais individuais na organização (a socialização (socialization - S), a externalização (externalization - E), a combinação (combination $-C$ ) e a internalização (internalization - I)) ; já Huber (1991) descreve subprocessos que ocorrem em nível organizacional, resultado de interações em grupo (a coleta e distribuição de informações, a interpretação, a memória organizacional e a desaprendizagem). 
A representação gráfica da somatória dos resultados desses subprocessos no tempo forma uma curva, com quatro tipos de inclinação, como mostrado na Figura 3.1:

- as inclinações suaves ( $\mathbf{A}$ ) representam a coleta e o intercâmbio de informações, na maioria das vezes baseados em algum tipo de interação social; seriam correspondentes aos subprocessos de coleta e distribuição de informações de Huber (1991), ou às etapas de socialização e externalização descritas por Nonaka (1991); esses subprocessos não costumam provocar grandes alterações no código da organização (no gráfico, o $\Delta y$ é pequeno).

- as inclinações mais fortes ( $\sqrt{\mathbf{B}})$ representam o processamento e o armazenamento dessas informações sob a forma de novo conhecimento; são correspondentes aos subprocessos de interpretação e memória organizacional de Huber (1991), ou às etapas de combinação e internalização descritas por Nonaka (1991); esses subprocessos costumam provocar as maiores alterações no código da organização (no gráfico, o $\Delta$ y é grande).

- também há inclinações negativas, correspondentes ao subprocesso de desaprendizagem (C) de Huber (1991), ou nulas, correspondentes aos períodos sem aprendizagem ( D ); há perda no código da organização $(\Delta y<0)$, ou este permanece estável $(\Delta \mathrm{y}=0)$, respectivamente.

A Figura 3.1 ilustra as sucessivas alterações no tempo. O "nível do código", representado pela ordenada, corresponde ao nível de conhecimento da empresa, composto pela somatória de tecnologias, procedimentos, normas, regras, formas, linguagem e crenças em toda a organização.

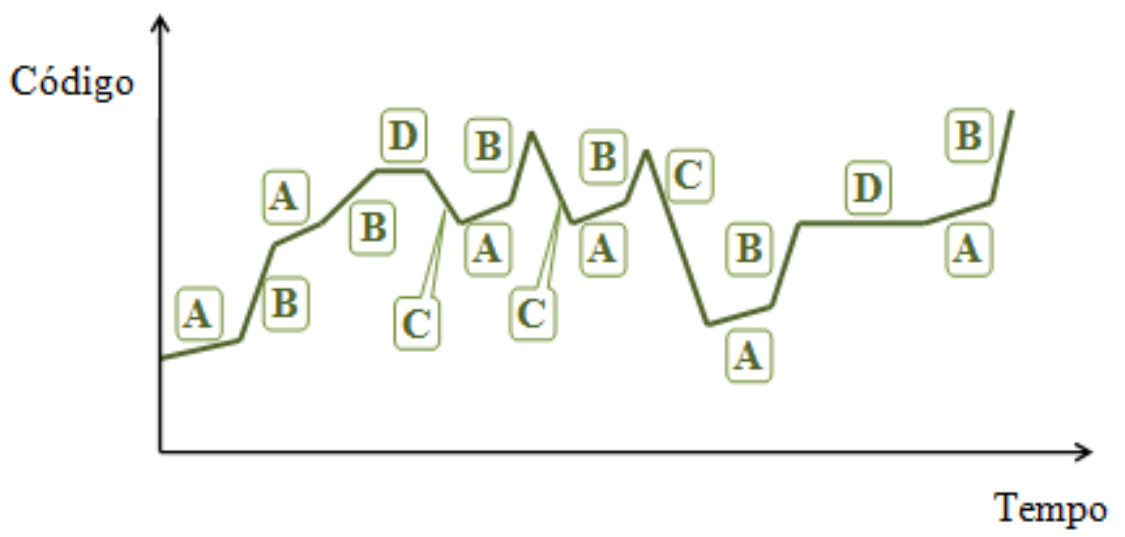

Figura 3.1 - Ilustração dos subprocessos de aprendizagem organizacional

Como há equifinalidade de sistemas, entretanto, após um certo período já não é tão importante verificar quais subprocessos foram executados e com qual frequência, conforme ilustrado na Figura 3.2. A variação do código das empresas, "C", que é a diferença que ocorreu no código entre o tempo $\mathrm{T}_{0}$ e o tempo $\mathrm{T}_{\mathrm{t}}$, é a mesma para todas. 
O conceito importante, neste caso, é que o código da organização é alterado à medida em que os subprocessos de aprendizagem ocorrem, e estes dependem de interações sucessivas entre indivíduos e grupos. Assim, podemos dizer que a aprendizagem organizacional é o resultado de sucessivas interações entre indivíduos e grupos, gerando certa quantidade de alteração do código organizacional ao longo do tempo. Isso significa que a aprendizagem organizacional pode ser representada por um segmento de reta num plano cartesiano, com comprimento (o tempo, t) e inclinação (a quantidade de diferença no código, C) definidos.

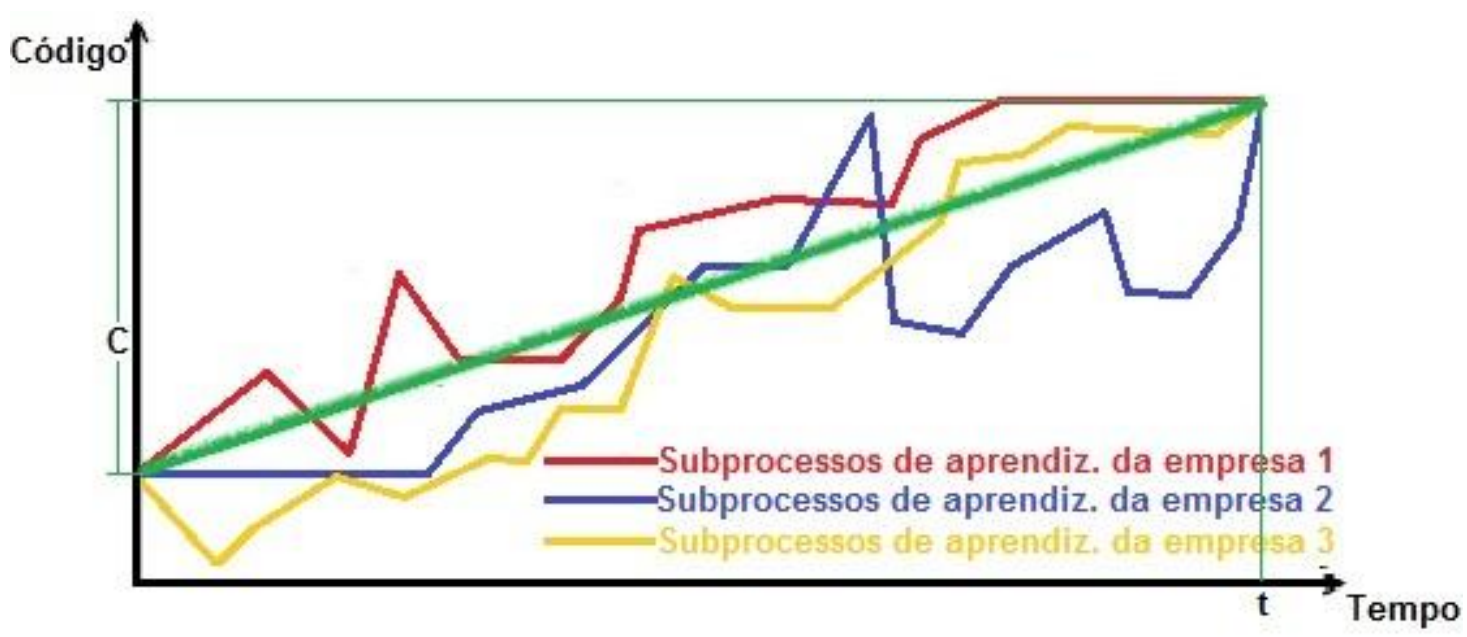

Figura 3.2 - Equifinalidade de Sistemas: o código da organização se altera independentemente dos subprocessos executados

Além da alteração do código com a passagem do tempo, também há um componente importante na discussão da Revisão Bibliográfica do Capítulo 2, que é o impacto da mudança do código sobre a organização (desempenho x variabilidade). Esse "resultado" da mudança pode ser ilustrado como uma direção para o segmento de reta, mais próximo ao eixo y, caso a alteração do código em determinado tempo tenha gerado melhora (ou piora) de desempenho, ou mais próximo ao eixo $\mathrm{x}$, caso a alteração do código em determinado tempo tenha gerado aumento (ou redução) de variabilidade.

Assim, a aprendizagem organizacional pode ser ilustrada como um vetor cujo módulo é a quantidade de alteração do código organizacional e a direção é a reta formada pelas quantidades de alteração no desempenho e na variabilidade em um plano cartesiano. O uso de um vetor também parece ser apropriado por que embute a ideia de movimento, a sucessão de diferentes interações (e subprocessos) no tempo, sem a qual não há alteração do código e, portanto, não há aprendizagem. A Figura 3.3 ilustra dois vetores de aprendizagem de módulos "C1" e "C2" e diferentes inclinações. A empresa azul apresenta uma quantidade "C1" de 
aprendizagem, na direção que a coloca como uma empresa do quadrante "2". Já a empresa vermelha apresenta uma quantidade "C2" de aprendizagem, na direção que a coloca como uma empresa do quadrante "4".

O quadrante 1 é caracterizado por baixa variabilidade e baixo desempenho, o que configuraria uma empresa com baixa aprendizagem em geral. Essa empresa provavelmente terá dificuldades em reagir a mudanças em seu ambiente, sejam quais forem, e apresentará baixa adaptação e baixa adaptabilidade.

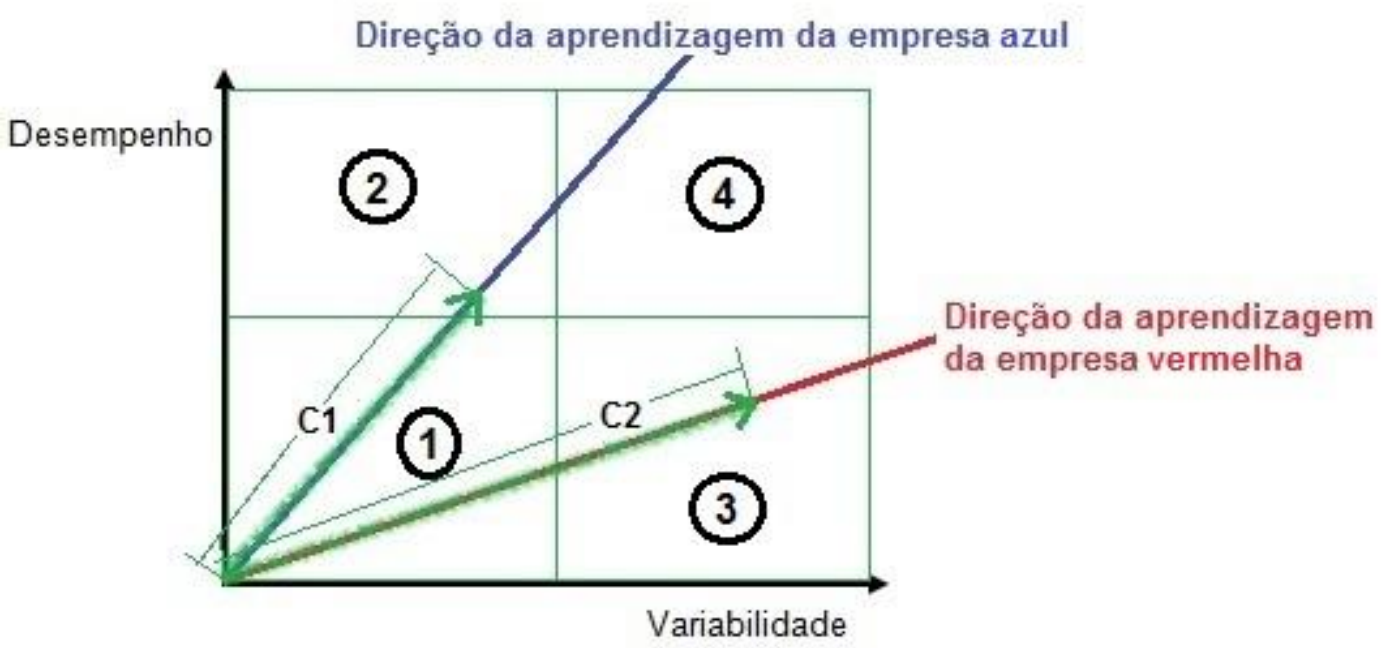

Figura 3.3 - Ilustração da aprendizagem organizacional

Já o quadrante 2, aonde está a empresa azul, apesar de apresentar baixa variabilidade, configura uma empresa com maior poder de alterar seu desempenho. Essa empresa reage bem às mudanças do ambiente, mas não cria novas respostas. É uma empresa basicamente reativa, capaz apenas de aprender adaptativamente. A empresa do quadrante 3, por outro lado, não é capaz de alterar seu desempenho de maneira significativa, mas consegue aumentar sua variabilidade. É o caso da empresa vermelha, que provavelmente lança novos produtos, processos e negócios a todo o momento, mas não consegue desenvolver nenhum deles. Essa empresa é capaz apenas de aprender generativamente, possui adaptabilidade, mas tem dificuldades de responder rapidamente ao seu ambiente (dificuldades de adaptação). Por fim, uma empresa do quadrante 4 é capaz de aumentar seu desempenho e a sua variabilidade ao mesmo tempo, tanto reagindo às mudanças no ambiente quanto aumentando seu repertório de respostas para o futuro. Essa empresa possui capacidade tanto de adaptação quanto de adaptabilidade e aprende tanto reativa quanto generativamente. É a empresa ambidestra descrita por Tushman e O'Reilly (1996). 


\subsection{Desempenho e Variabilidade}

Se a execução de subprocessos de aprendizagem organizacional em determinada ordem ou frequência parece não possuir impacto sobre a aprendizagem organizacional propriamente dita, o que então deve ser considerado num modelo conceitual que seja útil na gestão de pequenas empresas inovadoras? Seria interessante encontrar modelos de organizações que oferecessem condições para que o "vetor aprendizagem" tivesse o maior módulo possível, com a inclinação mais interessante para a empresa de acordo com o momento (é necessário se adaptar ou desenvolver adaptabilidade?).

A revisão teórica contribuiu com apenas um modelo prescritivo, o modelo das cinco disciplinas de Senge (1991), que cunhou a expressão "organizações de aprendizagem" justamente para representar as organizações em que a aprendizagem organizacional não só ocorre naturalmente, mas é gerenciada para gerar os melhores resultados competitivos. $\mathrm{O}$ modelo de Senge, entretanto, parece bastante abstrato à primeira vista.

Assim, um primeiro exercício teórico realizado foi analisar as definições para aprendizagem organizacional encontradas na literatura e extrair delas as características mencionadas que definiriam uma organização de aprendizagem. Revendo o material lido, pode-se dizer que Huber (1991) definiria a organização de aprendizagem como aquela que, através do processamento de informações, examina diferentes alternativas e escolhe racionalmente uma delas. Nonaka (1991), em seu modelo SECI, definiria as organizações de aprendizagem como aquelas que "criam conhecimento" através da aplicação em espiral dos processos de socialização, externalização, combinação e internalização. Pisano (1994) definiria a organização de aprendizagem como aquela que cria novas capacidades organizacionais através do projeto, implementação e replicação das rotinas e atividades nas quais é particularmente proficiente. Nevis e Dibella (1995) definiriam as organizações de aprendizagem como sistemas de aprendizagem caracterizados por competências essenciais bem desenvolvidas, uma atitude que apoia o desenvolvimento contínuo e a habilidade de, fundamentalmente, renovar ou revitalizar.

O interessante desse exercício é que ele revela, na nova interpretação das definições encontradas, a mesma dicotomia entre desempenho e variabilidade discutida inicialmente por March (1991). O Quadro 3.1 mostra como essa dicotomia se revela em cada uma das definiçõos apresentadas acima. 


\begin{tabular}{|c|c|c|}
\hline Autor & Variabilidade & Desempenho \\
\hline Huber (1991) & $\begin{array}{l}\text { através do processamento de } \\
\text { informações, examina as diferentes } \\
\text { alternativas }\end{array}$ & $\begin{array}{l}\text { escolhe racionalmente uma das } \\
\text { alternativas }\end{array}$ \\
\hline Nonaka (1991) & $\begin{array}{l}\text { aplicação em espiral dos processos } \\
\text { de combinação e internalização }\end{array}$ & $\begin{array}{l}\text { aplicação em espiral dos processos } \\
\text { de socialização e externalização }\end{array}$ \\
\hline Pisano (1994) & $\begin{array}{l}\text { cria novas capacidades } \\
\text { organizacionais }\end{array}$ & $\begin{array}{l}\text { através do projeto, implementação } \\
\text { e replicação de suas rotinas e } \\
\text { atividades nas quais é } \\
\text { particularmente proficiente }\end{array}$ \\
\hline $\begin{array}{c}\text { Nevis, Dibella } \\
(1995)\end{array}$ & $\begin{array}{l}\text { sistemas de aprendizagem } \\
\text { caracterizados por competências } \\
\text { essenciais bem desenvolvidas }\end{array}$ & $\begin{array}{l}\text { uma atitude que apóia o } \\
\text { desenvolvimento contínuo e a } \\
\text { habilidade de, fundamentalmente, } \\
\text { renovar ou revitalizar }\end{array}$ \\
\hline $\begin{array}{l}\text { Lei, Hitt e Bettis } \\
\qquad(1996)\end{array}$ & $\begin{array}{l}\text { coleção de habilidades e } \\
\text { capacidades únicas }\end{array}$ & $\begin{array}{l}\text { que influenciam a evolução da } \\
\text { empresa e suas alternativas de } \\
\text { crescimento estratégico }\end{array}$ \\
\hline $\begin{array}{l}\text { Brown e Duguid } \\
(1998)\end{array}$ & $\begin{array}{l}\text { habilidade de obter resultados } \\
\text { superiores aos do mercado reside } \\
\text { na geração contínua e na síntese } \\
\text { do conhecimento coletivo }\end{array}$ & $\begin{array}{l}\text { que constitui sua "competência } \\
\text { essencial" }\end{array}$ \\
\hline Senge (1990) & $\begin{array}{l}\text { alavancagem gerada pelo } \\
\text { pensamento sistêmico }\end{array}$ & $\begin{array}{l}\text { aplicação de pequenas e bem } \\
\text { focadas ações }\end{array}$ \\
\hline
\end{tabular}

Quadro 3.1 - Componentes de variabilidade e desempenho nas definições de A. O.

Dessa forma, as organizações de aprendizagem podem ser definidas como aquelas que gerenciam o seu nível de conhecimento (isto é, o desempenho e a variabilidade) de acordo com a sua estratégia formulada (isto é, privilegiando a adaptação, de curto prazo, ou a adaptabilidade, de longo prazo). Mas como se constrói uma organização de aprendizagem?

\subsection{Projeto de Organização de Aprendizagem}

É possível estabelecer um projeto de organização destinado ao gerenciamento do conhecimento a partir da análise dos vários componentes estruturais e contextuais de uma organização. Do ponto de vista estrutural as organizações de aprendizagem possuem características distintas de formalização, especialização, centralização, profissionalismo e relações (ou taxas de pessoal). Do ponto de vista contextual as organizações de aprendizagem possuem características distintas de cultura, ambiente, metas e estratégia, tamanho e tecnologia (DAFT, 2002).

1) Formalização - as organizações de aprendizagem possuem mecanismos para a transferência de conhecimentos tácitos ou heurísticos em conhecimentos explícitos, formalizados (NONAKA, 1991). 
Geralmente estes mecanismos estão apoiados por sistemas de informação que possuem como objetivo deslocar o lócus das competências críticas do nível individual para o nível organizacional. Ou seja, as organizações de aprendizagem terão como característica a abertura e a abrangência da comunicação (KONTOGHIORGHES; AWBRE; FEURIG, 2005), apoiada por um sistema de informações que conecte "pessoas com conhecimento codificado reutilizável" e "facilite conversas e a troca de conhecimento tácito" (DAFT, 2002). Um sistema de informações eficiente deve poder armazenar e disponibilizar três competências básicas para a organização:

i) diagnóstico de problemas em profundidade - ou a capacidade de aprendizagem em laço duplo (ARGYRIS, 1977);

ii) acesso e interação com pessoas ou entidades úteis ou importantes;

iii) localização de informações e recursos críticos. A avaliação do sistema de informação deve considerar sua acessibilidade, sua confiabilidade e sua "ownability", ou seja, a capacidade de se retro-alimentar (HUBER, 1991).

Essa característica se relaciona à quarta disciplina de Senge (1990), o aprendizado em grupo: é necessário instigar a "franqueza participativa" (liberdade de se falar o que se quer) e a "franqueza reflexiva" (questionar o modo de pensar).

2) Especialização e Hierarquia de autoridade - o processo de aprendizagem depende das interações entre os membros da organização e da socialização de novos membros. Assim, as organizações de aprendizagem têm como característica a adoção de uma estrutura hierárquica "achatada", substituindo cargos por equipes e intensificando o diálogo intra e inter-grupos (KONTOGHIORGHES; AWBRE; FEURIG, 2005).

A formação das unidades operacionais prioriza pessoas capazes de resolver problemas em grupo, que tenham boa comunicação e que, ao contrário de serem especialistas, tenham conhecimentos multidisciplinares. $\mathrm{O}$ sistema de carreira destas empresas também difere do tradicional (de definições e atribuições de cargos claras e delimitadas), criando novas relações e espaços organizacionais e adotando sistemas de benefício e recompensa mais flexíveis, que reconhecem e apóiam o aprendizado (SENGE, 1990; MARCH, 1991; FLEURY; FLEURY, 1995; DAFT, 2002; KONTOGHIORGHES; AWBRE; FEURIG, 2005). 
Essa característica se relaciona à quinta disciplina de Senge (1990), o raciocínio sistêmico, no qual a empresa é vista como um conjunto de "micromundos", e não uma estrutura departamentalizada.

3) Centralização - as organizações de aprendizagem tendem a ser descentralizadas, com a ênfase no controle sobre a integração e disseminação de informações ao invés de controle sobre a execução das tarefas. A crescente complexidade das próprias organizações e do ambiente em que estão inseridas cria a necessidade de considerar não apenas uma unidade de controle, ou relações lineares de causa e efeito, mas sim as inter-relações de eventos e objetivos, ou seja, quinta disciplina de Senge (1990), o raciocínio sistêmico (SENGE; KURPIUS, 1993; NEVIS; DIBELLA; GOULD, 1995; BITENCOURT; GONÇALO, 1999).

Além disso, essa característica se relaciona à terceira disciplina de Senge (1990), o objetivo comum. A centralização das decisões é substituída pela construção de uma visão compartilhada, ou seja, da criação iterativa de um objetivo comum que promova os interesses pessoais e organizacionais simultaneamente, criando um alto fator de engajamento e reduzindo a necessidade de controle local.

4) Profissionalismo - as organizações de aprendizagem precisam investir no desenvolvimento de competências individuais para que estas possam ser convertidas em competências organizacionais. Assim, as organizações de aprendizagem se caracterizam pelo investimento maciço e constante em capacitação e desenvolvimento de pessoal (KONTOGHIORGHES; AWBRE; FEURIG, 2005), pelo controle da rotatividade de pessoal, pela terceirização de processos de forma a minimizar a desaprendizagem deletéria e pelo empoderamento dos seus funcionários, ou seja, pela atenção às mudanças atitudinais pessoais, que se refletirão em mudanças organizacionais. (LEVITT; MARCH, 1988; SENGE; KURPIUS, 1993; BITENCOURT; GONÇALO, 1999)

Essas mudanças atitudinais pessoais dependem de um processo interno ao indivíduo e se relacionam à primeira disciplina de Senge (1990), o domínio pessoal, segundo a qual cada um deve buscar conhecer seus próprios limites e necessidades e definir suas formas de contribuição. As organizações de aprendizagem, portanto, abrem espaço para processos de descobrimento, de questionamento e de reflexão voltados ao auto-conhecimento.

Além disso, o auto-conhecimento também é importante para a aplicação da segunda disciplina de Senge (1990), os modelos mentais (idéias arraigadas, 
generalizações ou imagens que influenciam a maneira de encarar o mundo e as atitudes das pessoas, muitas vezes de forma inconsciente). Se os modelos mentais que norteiam as tomadas de decisão individuais e coletivas forem conscientes e explícitos será possível utilizar conhecimentos antigos e novos para aumentar a racionalidade das decisões, ou mesmo para aqueles alterar modelos mentais superados ou que não sejam interessantes para o indivíduo ou a organização.

5) Taxas de pessoal. O nível de conhecimento organizacional pode ser considerado com o ponto de equilíbrio entre a aprendizagem individual (indivíduos aprendendo o código da organização) e a aprendizagem organizacional (a organização alterando o seu código através da influência de informações novas trazidas pelos indivíduos). Nesse ponto de equilíbrio todos os indivíduos e o código compartilham a mesma crença sobre uma certa dimensão. Dessa forma, é possível concluir que este ponto será alterado em função das taxas de aprendizagem individuais e do nível de socialização (exposição de novos indivíduos ao código) da organização (MARCH, 1991). .

Taxas altas de aprendizagem resultam em equilíbrio mais rápido, o que significa que o aprendizado pessoal é maior a curto prazo, mas restrito a longo prazo, e o aprendizado organizacional é inibido (já que os indivíduos que se socializam rapidamente não alteram o código). Inversamente, taxas baixas de aprendizagem (ou de socialização) resultam em mais conhecimento no equilíbrio porque permitem maior exploração de alternativas e melhor balanceamento no desenvolvimento de competências especializadas (o que aumenta a variabilidade) (MARCH, 1991).

O aprendizado mútuo (entre pessoas e organização), a longo prazo, tem uma propriedade degenerativa em relação à turbulência exógena, isto é, conforme indivíduos e crenças convergem, as possibilidades para alterações se reduzem, reduzindo o conhecimento tanto dos indivíduos quanto das organizações face às mudanças do ambiente. Se o equilíbrio for mantido indefinidamente, a probabilidade de adaptação da organização ao ambiente decairá até se tornar aleatória (MARCH, 1991).

A otimização do conhecimento (em seu maior nível possível) ocorre quando o código aprende rápido de indivíduos que se socializam lentamente, mas, na prática, não há incentivos óbvios para os que aprendem devagar, considerando-se que não só as organizações como também os indivíduos estão competindo por posições em seu 
ambiente e os processos de contratação tendem a selecionar pessoas que aprendem rápido (MARCH, 1991).

A alternativa prática para contornar os problemas de manutenção do equilíbrio e de priorização do aprendizado rápido é a manutenção de certa taxa de rotatividade (isto é, mudanças na afiliação organizacional), que introduza variabilidade sem depender de quem aprende devagar. A troca constante de pessoas diminui o aprendizado pessoal, mas aumenta o organizacional, até um ponto em que se torna excessivo, criando ênfase demasiada na variabilidade em detrimento do desempenho. Outra consideração importante é que a substituição de pessoas por outras com crenças próximas ao código não gerará variabilidade e, pior, reduzirá o desempenho. Desse modo, as organizações de aprendizagem terão como características o controle das taxas de rotatividade e políticas de contratação que promovam a variabilidade (MARCH, 1991).

6) Tamanho - as organizações de aprendizagem não são definidas pelo seu tamanho, mas pelo alto grau de integração entre todos os seus componentes. A falta de integração pode levar a problemas de "miopia de aprendizado", de três formas:

i) "miopia temporal": o processo de aprendizado tende a sacrificar o longo prazo em detrimento do curto prazo, validando e compensando o desenvolvimento de competências distintivas e de nichos, que, por sua vez, comprometem o desenvolvimento de capacidades além destas competências e nichos - é o ciclo de repressão do conhecimento em ação;

ii) "miopia espacial": o processo de aprendizado tende a ressaltar os efeitos que ocorrem mais próximos de quem está aprendendo, criando uma distorção na subordinação de interesses; os interesses de indivíduos ou de unidades - ou subunidades - da organização sobrepujam os interesses da organização;

iii) "miopia do fracasso": o processo de aprendizado tende a super-amostrar os sucessos e sub-amostrar os fracassos das experiências organizacionais, produzindo um excesso de confiança que, por sua vez, gera a antecipação tendenciosamente favorável de resultados.

Embora a miopia de aprendizagem possa ter um efeito positivo (promovendo a aprendizagem generativa pela redução das pressões em direção à aprendizagem adaptativa), também há um efeito sobre a análise e a assunção de riscos (LEVINTHAL; MARCH, 1993). 
7) Tecnologia organizacional - as organizações de aprendizagem possuem competências específicas distintas, raras, valiosas, não substituíveis e difíceis de serem imitadas. Essas competências se traduzem em tecnologias de processo ou de produto que geram vantagem competitiva. Assim, as organizações de aprendizagem têm como característica a adoção de tecnologias organizacionais alinhadas à sua estratégia e a alocação de recursos compatível às necessidades de tais tecnologias, ou seja, a tecnologia organizacional não será um fator definidor para as organizações de aprendizagem, que poderão ser artesanais, orgânicas, burocráticas, assumindo formas variadas, de acordo com a sua necessidade (LADO; WILSON, 1994; FLEURY; FLEURY, 1995; NEVIS; DIBELLA; GOULD, 1995; BITENCOURT; GONÇALO, 1999; KONTOGHIORGHES; AWBRE; FEURIG, 2005).

8) Ambiente - ao analisarmos o ambiente no qual as organizações de aprendizagem atuam, geralmente caracterizado pela velocidade das alterações tecnológicas e pela demanda fragmentada de mercado (MCGILL; SLOCUM; LEI, 1992), devemos considerar a discussão de desempenho e variabilidade em 2.2.2: quanto menor o número de competidores, maior a importância do valor do desempenho. Quanto maior o número de competidores, maior a importância do valor da variabilidade. A variabilidade aumenta as chances de alcançar as primeiras posições, ao passo que a eficiência diminui as chances de ficar em último (MARCH, 1991).

Por outro lado, o ambiente é ubíquo ao conceito de aprendizagem organizacional aqui desenvolvido, já que os subprocessos necessários à sua existência dependem da interação com o ambiente (HUBER, 1991; NONAKA, 1991).

9) Metas e estratégias - as organizações de aprendizagem tendem a valorizar estratégias relacionadas à inovação e assumem mais riscos (KONTOGHIORGHES; AWBRE; FEURIG, 2005). O sistema de definição e correção de metas e objetivos valoriza o longo prazo e beneficia as decisões que respondem aos interesses da organização como um todo, explicitando erros e fracassos de maneira a reduzir o otimismo excessivo na análise de riscos, porém sem inibir a experimentação e a aprendizagem generativa, ou seja, há um estímulo concreto para a aprendizagem em laço duplo (ARGYRIS, 1977; LEVINTHAL; MARCH, 1993).

Há uma relação de reciprocidade: não só a estratégia orienta o aprendizado, mas o processo de aprendizagem faz parte da estratégia da empresa, que é direcionada para o futuro e para a criação do novo, numa relação pró-ativa entre a 
organização e seu ambiente. Além disso, a aprendizagem define a formação de redes e alianças estratégicas, que passam a ser formadas em volta dos fluxos de conhecimento (SENGE, 1990; MARCH, 1991; SENGE; KURPIUS, 1993; FLEURY; FLEURY, 1995; NEVIS; DIBELLA; GOULD, 1995).

10) Cultura - as organizações de aprendizagem tendem a promover um ambiente que facilite a troca de informações e a admissão de erros, gerando um aprendizado coletivo, compartilhado e alinhado a um objetivo comum, permitindo não só a consolidação de competências individuais como a reflexão sobre modelos mentais e o aprendizado de laço duplo (ARGYRIS, 1977).

Tanto Tushman e O’Reilly III (1996) quanto Nonaka (1991) ressaltam o impacto da cultura da organização sobre sua capacidade de aprendizagem e, consequentemente, sobre o seu sucesso, ressaltando a importância do principal dirigente em agir como um propagador da "visão compartilhada", ou um "guardachuva conceitual", gerenciando primariamente a cultura organizacional.

Senge (1990) ressalta a mudança do papel do dirigente de uma organização de aprendizagem: um projetista (não mais o comandante do navio - aquele que define para onde o navio vai - mas sim seu projetista - o que define o que o navio é capaz de fazer), um guia (aquele que define um ideal que transcende as metas e objetivos cotidianos) e um professor (ensinando a realidade em quatro níveis distintos: os eventos a serem esperados e/ou antecipados, os padrões de comportamento a serem seguidos, as estruturas sistêmicas a serem compreendidas e o nível ideal a ser comumente aspirado).

São características marcantes da cultura das organizações que aprendem: a priorização da variabilidade, a aceitação da ambiguidade e a gestão do conhecimento (SENGE, 1990; SENGE; KURPIUS, 1993; FLEURY; FLEURY, 1995; BITENCOURT; GONÇALO, 1999; KONTOGHIORGHES; AWBRE; FEURIG, 2005)

Esse projeto de organização de aprendizagem parece mais concreto e passível de implementação, mas como ele se relaciona ao mapa conceitual desenvolvido? Como esses fatores se relacionam à melhora de desempenho ou ao aumento da variabilidade? Uma nova análise da literatura indicou que certos fatores estruturais e contextuais não só apresentam características distintas em relação ao desempenho ou à variabilidade, mas também que se apresentam inter-relacionados: a presença de um implica a presença dos demais, tornando seu gerenciamento bastante simplificado, quase intuitivo. As características inter-relacionadas de 
formalização, especialização, hierarquia, centralização, profissionalismo, taxas de pessoal, tamanho, tecnologia, ambiente, metas e estratégias e cultura geram dois construtos que compõem o mapa conceitual, a aprendizagem horizontal e a aprendizagem vertical.

\subsection{Aprendizagem Horizontal e Aprendizagem Vertical}

O mapa conceitual de aprendizagem organizacional pode ser descrito como a soma de dois vetores, representando a aprendizagem horizontal e a aprendizagem vertical.

Conceitualmente, a aprendizagem organizacional representaria a soma total dos efeitos de dois tipos de aprendizagem:

- a primeira, denominada "aprendizagem vertical", voltada à correção de erros, constituída por uma somatória de interações individuais e em grupo que geram uma alteração pontual no código da empresa para melhora do desempenho (provavelmente relacionada à capacidade técnica e decorrente da solução de um problema através do emprego de raciocínio linear e dependente de histórico). Ela atinge um grupo isolado de pessoas e não provoca efeitos em outras áreas da organização, gerando resultados a curto prazo (de adaptação). Esse provavelmente é o tipo de aprendizagem que todas as empresas ativas apresentam;

- a segunda, denominada "aprendizagem horizontal", é voltada à análise crítica de erros e correção das suas causas, constituída por uma somatória de interações individuais e em grupo que geram uma alteração no código da empresa como um todo, em nível sistêmico, integrado, multidisciplinar, alcançado vários departamentos e níveis hierárquicos, gerando variabilidade e resultados a longo prazo (adaptabilidade).

Para que ela ocorra há necessidade de forte integração entre equipes ou áreas da empresa, pois seu efeito se reflete em toda a organização. A aprendizagem horizontal garante a sobrevivência da organização a longo prazo (adaptabilidade) e é provavelmente o tipo de aprendizagem que está relacionada à inovação. O Quadro 3.2 ilustra como os construtos foram desenvolvidos.

A aprendizagem vertical é uma aprendizagem adaptativa, mas possui características adicionais: ocorre em ambientes mais hierarquizados ou fica circunscrita a grupos isolados, envolve maior especialização de pessoas e processos, tomadas de decisão mais centralizadas e raciocínio linear (de causa e efeito), reflete uma cultura menos propensa à mudança (onde o aprendizado de laço único prevalece) e implica a adoção de uma estratégia de priorização do desempenho, aumentando a adaptação da empresa. 


\begin{tabular}{|c|c|c|}
\hline Componente & Aprendizagem Vertical & Aprendizagem Horizontal \\
\hline Tipo de Aprendizagem & Adaptativa & Generativa \\
\hline Hierarquia & Estrutura mais hierarouizada & $\begin{array}{l}\text { Estrutura pouco hierárquica, } \\
\text { "achatada" }\end{array}$ \\
\hline Especialização & Especializaçào técnica & $\begin{array}{c}\text { Multidisciplinaridade, trabalho em } \\
\text { equipe } \\
\end{array}$ \\
\hline Centralização & Alta, raciocinio linear & 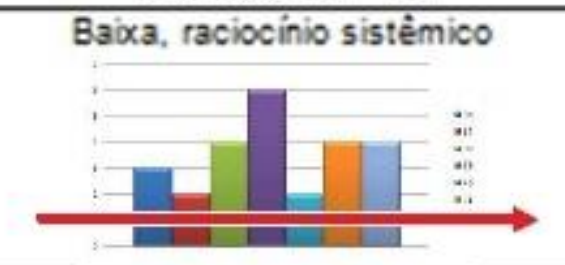 \\
\hline Tamanho (integração) & $\begin{array}{l}\text { Grupos isolados, pouca } \\
\text { integraçáo }\end{array}$ & $\begin{array}{l}\text { Grupos inter-relacionados, muita } \\
\text { integraçáo }\end{array}$ \\
\hline Estratégia & 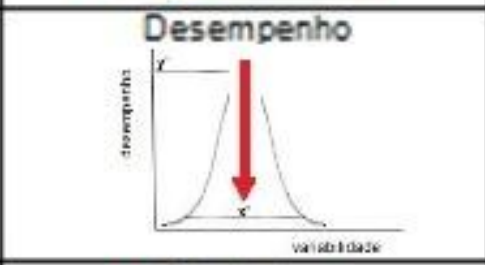 & $\underset{r}{\frac{2}{r}}$ \\
\hline Cultura & & 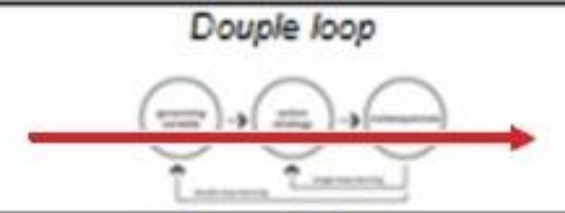 \\
\hline Resultado & Adaptacăo & Adaptabilidade \\
\hline Efeito & Localizado & Se estende por toda a organizaçào \\
\hline
\end{tabular}

Quadro 3.2 - Formação visual dos construtos de aprendizagem horizontal e vertical 
Para que ela ocorra não há necessidade de forte integração entre equipes ou áreas da empresa, pois seu efeito é sempre localizado. A aprendizagem vertical garante a sobrevivência da organização a curto prazo (adaptação).

Já a aprendizagem horizontal é uma aprendizagem do tipo generativa, mas também ocorre em ambientes pouco hierarquizados, com predominância de trabalho em equipes multidisciplinares bastante integradas ou com alto grau de inter-relacionamento, envolve tomadas de decisão descentralizadas (cada equipe ou unidade possui bastante autonomia) e raciocínio sistêmico, reflete uma cultura com alta aceitação de ambiguidade e mudança (onde o aprendizado de laço duplo efetivamente ocorre) e implica a adoção de uma estratégia de priorização da variabilidade, aumentando a adaptabilidade da empresa.

A Figura 3.4 ilustra os construtos:

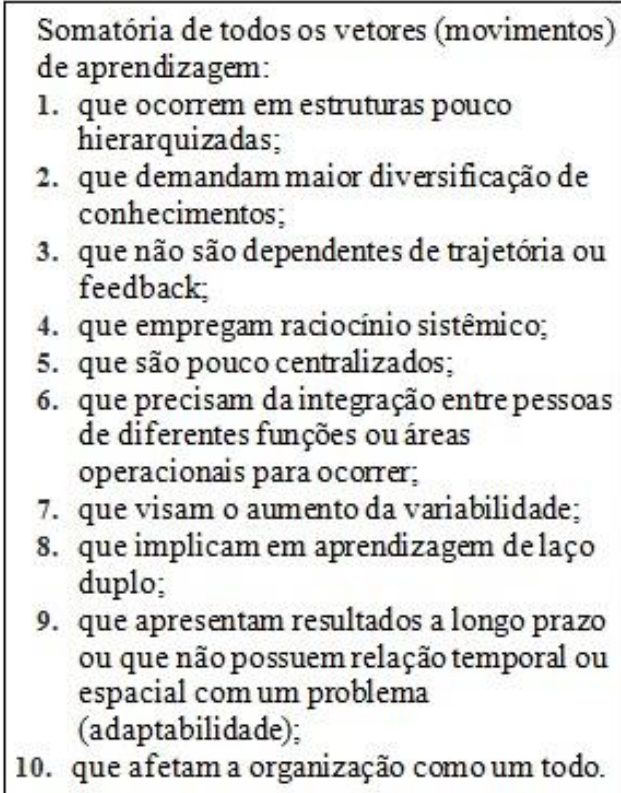

1. que ocorrem em estruturas pouco hierarquizadas;

2. que demandam maior diversificação de conhecimentos;

3. que não são dependentes de trajetória ou feedback;

4. que empregam raciocínio sistêmico;

5. que são pouco centralizados;

6. que precisam da integração entre pessoas de diferentes funções ou áreas operacionais para ocorrer;

7. que visam o aumento da variabilidade;

8. que implicam em aprendizagem de laço duplo;

9. que apresentam resultados a longo prazo ou que não possuem relação temporal ou espacial com um problema

(adaptabilidade);

10. que afetam a organização como um todo.

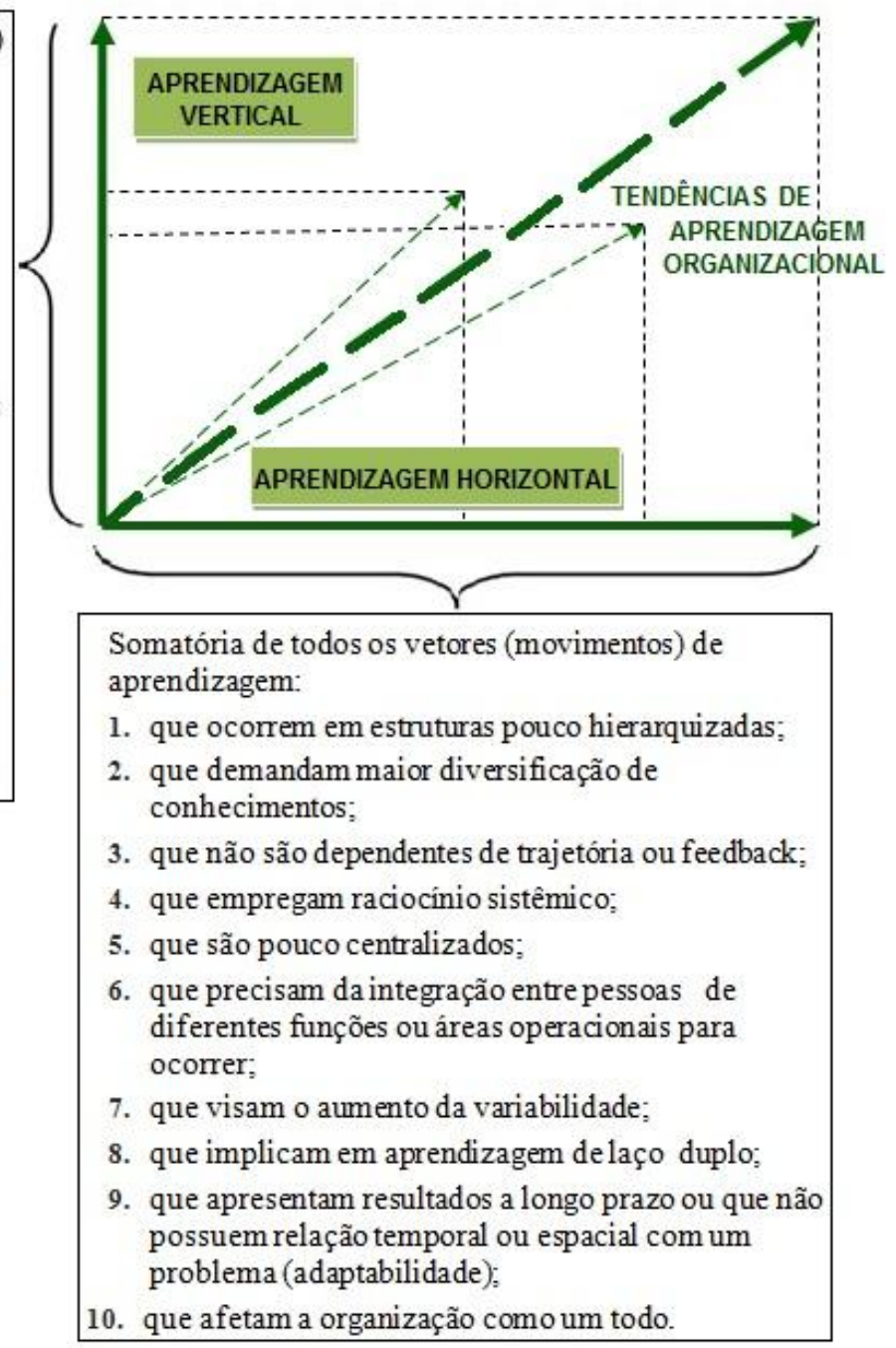

Figura 3.4 - Mapa conceitual dos Componentes da Aprendizagem Organizacional (Aprendizagem Horizontal e Aprendizagem Vertical) 
Todas as organizações estão sujeitas a dois ciclos de retro-alimentação opostos: em um sentido a linearidade e a dependência da trajetória do aprendizado vertical inibem o aprendizado horizontal, que por sua vez consome recursos que poderiam ser aplicados para a melhora do desempenho, inibindo assim, a aprendizagem vertical. No sentido oposto, a aprendizagem vertical aumenta o repertório das organizações, estimulando a aprendizagem horizontal, que por sua vez cria soluções novas a serem implementadas, exigindo a aprendizagem vertical. A sobreposição desses dois ciclos gera um ponto de equilíbrio dinâmico, a tendência de direção da aprendizagem organizacional da empresa.

Quanto mais próximo do eixo horizontal for o nível de equilíbrio (tendência para a aprendizagem horizontal), mais inovadora será a empresa. Por outro lado, quanto mais próximo do eixo vertical for o nível de equilíbrio (tendência para a aprendizagem vertical), menos inovadora será a empresa. Se a organização conseguir definir características estruturais (hierarquia, especialização, centralização e tamanho) e contextuais (estratégia, cultura, resultado e efeito) condizentes com aquelas compatíveis com a aprendizagem horizontal, provavelmente será uma organização inovadora.

Assim sendo, empresas jovens, organizações que estão no momento de lançamento ou no início do ciclo de vida de um produto e grupos de pesquisa provavelmente se configuram como mais inovadores, ou priorizam a aprendizagem horizontal. Por outro lado, empresas mais maduras, em processo de crescimento ou no final do ciclo de vida de um produto tendem a priorizar a aprendizagem vertical, inovando menos e aprimorando processos, produtos e modelos de negócio já existentes. 


\section{Pequenas Empresas: Conceitos Relevantes}

Após a criação do mapa conceitual teórico para o tema geral, a etapa seguinte é a compreensão da realidade das pequenas empresas. É necessário, portanto, fazer primeiramente uma revisão bibliográfica do tema.

\subsection{Pequenas Empresas e Organizações}

Vários teóricos organizacionais descrevem a pequena empresa como uma "pequena grande empresa" (organização com as mesmas características das grandes empresas) ou uma empresa em fase de se tornar grande (ou como uma fase de "transição" que não vale a pena ser estudada) (JULIEN, 1997).

O problema em relação à primeira descrição é que as pequenas empresas, ao contrário das grandes empresas, nem sempre são organizações. Há cinco características básicas que definem as grandes organizações burocráticas, e que nem sempre estão presentes nas pequenas empresas:

i) sistema social que divide o trabalho de forma sistemática e coerente;

ii) regidas pelo princípio fundamental da eficiência;

iii) são impessoais;

iv) são administradas;

v) possuem uma finalidade específica, que é o desenvolvimento econômico (PEREIRA e MOTTA; 1983).

Uma outra abordagem é o modelo ideal descrito por Weber (apud CARVALHO, 2010), que descreve as organizações burocráticas como:

i) estruturas formais;

ii) legitimadas pela autoridade racional-legal;

iii) regidas por critérios impessoais;

iv) dirigidas por administradores profissionais;

v) com predominância da ação social racional no tocante a fins.

Entretanto, a maioria das pequenas empresas não conseguem estabelecer uma estrutura impessoal e formal por causa do número reduzido de pessoas que as compõem. Isso significa que elas não são impessoais, pois a perda de alguma pessoa chave pode significar o fim da empresa. Tampouco a autoridade é legitimada pela autoridade racional-legal, já que algumas 
pequenas empresas possuem um tipo de liderança mais próximo ao tradicional ou ao carismático. Por fim, sua finalidade específica não se restringe apenas o resultado financeiro ou ao uso eficiente dos recursos. Segundo a tipologia de Weber, "há quatro tipos de ação social: afetiva, tradicional, racional no tocante a valores e racional no tocante a fins" (CARVALHO, 2010, p. 91).

As grandes empresas seguem apenas um tipo de ação: a racional no tocante a fins (o desenvolvimento econômico). Já as pequenas empresas seguem ações sociais diversas: afetivas (com a prática frequente do nepotismo, por exemplo) tradicionais (como no caso da empresa familiar, muitas vezes herdada dos pais, que é gerida com base nas tradições e não na eficiência) ou racional no tocante a valores (como no caso de dirigentes de pequenas empresas que querem independência ou sobrevivência, em detrimento de crescimento financeiro) (CARVALHO, 2010).

Isso significa que as pequenas empresas não estão, necessariamente, a caminho de tornarem-se grandes, ou que seu tamanho represente uma fase de "transição". Com efeito,

"vários autores (WELSH \& WHITE, 1981; FARAH, 1985; GOLDE, 1986; GIMENEZ, 1988; LONGENECKER et al., 1997; LEONE, 1999, TERENCE, 2002) defendem a necessidade de se estudar um enfoque diferenciado de gestão devido ao fato de as pequenas empresas possuírem algumas características específicas que as distinguem das de grande porte" (CÊRA; ESCRIVÃO FILHO, 2003, p. 796).

A primeira implicação dessa premissa é que é necessário estudar a pequena empresa como uma entidade diversa da grande empresa, criando assim uma teoria específica. A segunda é que os estudos da pequena empresa não podem se basear nas mesmas premissas dos estudos da grande empresa (ou seja, não é possível partir do princípio que pequenas empresas são organizações burocráticas):

"Dandridge (1979) acredita [que] é mais útil estudar a pequena empresa a partir dos relacionamentos pessoais existentes na família do que com as teorias das grandes empresas. Da mesma forma, Escrivão Filho (2006) acredita que é mais apropriado estudar o que se denomina de grupo social ou organização social para compreender sistemas que não são grandes e burocratizados como a pequena empresa" (CARVALHO, 2010, p. 98).

\subsection{Caracterização e Tipologia das Pequenas Empresas}

O primeiro desafio que se impõe à formação de um corpo teórico sobre o assunto, entretanto, é que, ao contrário das grandes organizações burocráticas, que seguem critérios 
racionais e estruturais razoavelmente previsíveis e padronizados, a principal característica das pequenas empresas é a sua heterogeneidade (JULIEN, 1997; LEONE, 1999; CÊRA; ESCRIVÃO FILHO, 2003; MAZZALI, 2008).

"O que há de comum entre uma pessoa com licenciatura que abre uma pequena mercearia em sua cidadezinha ou o estudante que, terminando seus estudos, alugue algumas máquinas de fotocópia para oferecer um serviço próximo ao seu colégio e o operário especializado que, confiante em sua experiência em uma grande empresa, decide partir por sua própria conta ou o informático que monta em uma incubadora uma empresa informática de ponta?" (JULIEN, 1997)

E como relacionar os exemplos acima aos artesãos independentes, às pequenas firmas "alternativas" ou voltadas à economia social, ao trabalhador autônomo, aos imigrantes empreendedores, ao empreendedorismo étnico ou ao empreendedorismo de necessidade (JULIEN, 1997; CÊRA; ESCRIVÃO FILHO, 2003)?

Tradicionalmente, a pequena empresa é descrita através do modelo de estrutura simples de Mintzberg: orgânica, de comportamentos pouco formalizados, com tecnoestrutura pouco desenvolvida, divisão imprecisa do trabalho e pequena hierarquia de gestão, organizando-se principalmente através da supervisão direta (MINTZBERG, 1999). Drucker (1981, p. 221) propõe que "uma empresa é do tamanho da estrutura administrativa que necessita" e identifica quatro "tamanhos" de empresa:

i) a empresa pequena, que possui um nível administrativo ("chefe" e funcionários) e pouca especialização de cargos;

ii) a empresa média, que precisa de uma equipe de administração, pressupondo pelo menos dois níveis administrativos e a definição clara de cargos técnicos;

iii) a empresa grande, que precisa de uma equipe no cargo de cúpula, adotando uma estrutura de "descentralização federal" e

iv) a empresa muito grande, que é grande demais e complexa demais para não ser gerida por equipes em período integral e através de uma estrutura administrativa "federalizada".

Meijaard e Brand (2005), entretanto, ressaltam a grande variedade de padrões no tocante à complexidade hierárquica, divisão funcional, especialização de tarefas e coordenação:

"O mito de que "empresas pequenas são informais, desestruturadas e centralizadas parece ser falso. A departamentalização de empresas maiores é mais complexa, mas muitas das empresas com menos empregados são 
bastante complexas em sua estrutura. A diversidade de tarefas diminui e a especialização dos funcionários aumenta conforme as empresas pequenas se tornam maiores, mas - novamente - um grande grupo de empresas menores apresentam mais especialização do que empresas maiores" (MEIJAARD; BRAND; MOSSELMAN, 2005, p.89).

Diferentes critérios têm sido adotados face à impossibilidade de definir uma caracterização genérica de pequena empresa. Estes possuem propósitos diferentes, para tipificar grupos ou reconhecer características específicas. O critério de tipificação mais simples seria, em princípio, o quantitativo, adotando como parâmetros o número de funcionários, um indicador financeiro (como, por exemplo, o faturamento bruto anual) ou a fatia de mercado que a empresa domina (JULIEN, 1997). Entretanto, é importante lembrar que, qualquer que seja o parâmetro quantitativo adotado, ele será inevitavelmente arbitrário, definido em função de seu propósito, e não será necessariamente aplicável a todas as áreas ou tipos de negócios (TERENCE, 2008).

No Brasil a classificação financeira é de origem legal e aplicada à cobrança de impostos e à avaliação de empresas pelas instituições financeiras. Há três entidades que classificam o porte das empresas: "o Ministério do Trabalho e Emprego, por meio da Relação Anual de Informações Sociais (RAIS); o Instituto Brasileiro de Geografia e Estatística (IBGE); o Serviço Brasileiro de Apoio às Micro e Pequenas Empresas (SEBRAE)" (ZICA; MARTINS, 2008).

O Quadro 4.1, na próxima página, resume os principais parâmetros de classificação quantitativa adotados no Brasil. Embora a maioria das classificações empreguem dados financeiros, o SEBRAE classifica o porte das empresas pelo número de funcionários. Esta classificação é a que tem sido adotada na maioria das pesquisas sobre pequenas empresas brasileiras que foram encontradas na revisão bibliográfica.

Além da heterogeneidade, outra característica importante das pequenas empresas é a sua volatilidade - o "campo de estudo" varia enormemente, com a criação e o fechamento constante de empresas (JULIEN, 1997). A pequena empresa não tem poder de influência perante grande parte das imposições do seu ambiente (legais, econômicas, políticas, concorrenciais). 
Quadro 4.1 - Critérios de classificação para micro, pequenas, médias e grandes empresas no Brasil, segundo número de empregados, receita operacional bruta anual e faturamento bruto anual, por grande grupo de atividade econômica

\begin{tabular}{|c|c|c|c|c|c|c|c|c|c|c|c|c|}
\hline \multirow{2}{*}{$\begin{array}{l}\text { INSTI- } \\
\text { TUIÇÃO }\end{array}$} & \multicolumn{4}{|c|}{ INDÚSTRIA } & \multicolumn{4}{|c|}{ COMÉRCIO } & \multicolumn{4}{|c|}{ SERVIÇOS } \\
\hline & MICRO & PEQUENA & MÉDIA & GRANDE & MICRO & PEQUENA & MÉDIA & GRANDE & MICRO & PEQUENA & MÉDIA & GRANDE \\
\hline \multicolumn{13}{|c|}{ PORTE DAS EMPRESAS SEGUNDO NÚMERO DE EMPREGADOS } \\
\hline SEBRAE & até 19 & 20 a 99 & $\begin{array}{c}100 \mathrm{a} \\
499\end{array}$ & $\begin{array}{c}\text { mais de } \\
499\end{array}$ & até 9 & 10 a 49 & 50 a 99 & mais 99 & até 9 & 10 a 49 & 50 a 99 & mais 99 \\
\hline \multicolumn{13}{|c|}{ PORTE DAS EMPRESAS SEGUNDO RECEITA OPERACIONAL BRUTA ANUAL (EM R\$) } \\
\hline BNDES & $\begin{array}{c}\text { até } 1.200 \\
\text { mil }\end{array}$ & $\begin{array}{l}1.200 \mathrm{mil} \mathrm{a} \\
10.500 \mathrm{mil}\end{array}$ & $\begin{array}{c}10.500 \text { mil } \\
\text { a } \\
60 \\
\text { milhões }\end{array}$ & $\begin{array}{c}\text { acima de } \\
60 \\
\text { milhões }\end{array}$ & $\begin{array}{c}\text { até } 1.200 \\
\text { mil }\end{array}$ & $\begin{array}{l}1.200 \mathrm{mil} \mathrm{a} \\
10.500 \mathrm{mil}\end{array}$ & $\begin{array}{c}10.500 \text { mil } \\
\text { a } 60 \\
\text { milhões }\end{array}$ & $\begin{array}{c}\text { acima de } \\
60 \\
\text { milhões }\end{array}$ & $\begin{array}{c}\text { até } 1.200 \\
\text { mil }\end{array}$ & $\begin{array}{l}1.200 \mathrm{mil} \mathrm{a} \\
10.500 \mathrm{mil}\end{array}$ & $\begin{array}{c}10.500 \text { mil } \\
\text { a } 60 \\
\text { milhões }\end{array}$ & $\begin{array}{c}\text { acima de } \\
60 \\
\text { milhões }\end{array}$ \\
\hline \multicolumn{13}{|c|}{ PORTE DAS EMPRESAS SEGUNDO FATURAMENTO BRUTO ANUAL (EM R\$) } \\
\hline $\begin{array}{c}\text { BANCO } \\
\text { DO } \\
\text { BRASIL }\end{array}$ & $\begin{array}{c}\text { até } 5 \\
\text { milhões }\end{array}$ & $\begin{array}{c}\text { até } 5 \\
\text { milhões }\end{array}$ & $\begin{array}{c}\text { entre } 5 \text { e } \\
100 \\
\text { milhões }\end{array}$ & $\begin{array}{c}\text { acima de } \\
100 \\
\text { milhões }\end{array}$ & $\begin{array}{c}\text { até } 5 \\
\text { milhões }\end{array}$ & $\begin{array}{c}\text { até } 5 \\
\text { milhões }\end{array}$ & $\begin{array}{c}\text { entre } 5 \text { e } \\
100 \\
\text { milhões }\end{array}$ & $\begin{array}{c}\text { acima de } \\
100 \\
\text { milhões }\end{array}$ & $\begin{array}{c}\text { até } 5 \\
\text { milhões }\end{array}$ & $\begin{array}{c}\text { até } 5 \\
\text { milhões }\end{array}$ & $\begin{array}{c}\text { entre } 5 \text { e } \\
100 \\
\text { milhões }\end{array}$ & $\begin{array}{c}\text { acima de } \\
100 \\
\text { milhões }\end{array}$ \\
\hline SIMPLES & $\begin{array}{c}\text { até } \\
120.000\end{array}$ & $\begin{array}{l}120.000 \mathrm{a} \\
1.200 .000\end{array}$ & - & - & $\begin{array}{c}\text { até } \\
120.000\end{array}$ & $\begin{array}{l}120.000 \mathrm{a} \\
1.200 .000\end{array}$ & - & - & $\begin{array}{c}\text { até } \\
120.000\end{array}$ & $\begin{array}{l}120.000 \mathrm{a} \\
1.200 .000\end{array}$ & - & - \\
\hline
\end{tabular}

Fonte: adaptado de Teixeira (2003) 
Inversamente, seu desempenho é fortemente influenciado pela estrutura do mercado em que estão inseridas. Empresas "dependentes" (fornecedoras ou distribuidoras de grandes empresas) estão diretamente sujeitas às decisões das grandes empresas, ao passo que as empresas "independentes" (as que não mantêm relações produtivas diretas com as grandes empresas) são as que apresentam maior volatilidade, refletindo - "não necessariamente de forma simultânea e com a mesma intensidade - os movimentos maiores de expansão e contração da economia dos diversos setores industriais em que se inserem" (CÊRA; ESCRIVÃO FILHO, 2003, p. 802).

Tipologias puramente quantitativas, portanto, não são suficientes para descrever um universo tão heterogêneo e volátil. Assim, na pesquisa de pequenas empresas, são mais utilizados critérios qualitativos, ou uma combinação de qualitativos e quantitativos. "A ciência funciona antes de tudo por generalização e por agrupamento; e o domínio das pequenas empresas não pode escapar, mesmo se isso pareça particularmente difícil de fazer" (JULIEN, 1997, p. 5). É preciso estabelecer uma abordagem de estudo baseada em características que são específicas das pequenas empresas, estão presentes na maioria das empresas estudadas, mesmo face à sua enorme heterogeneidade, e podem ser observadas em vários estágios de desenvolvimento (ou ciclo de vida) das mesmas, mesmo face à sua volatilidade.

Duas características principais, o tamanho destas empresas e sua relação assimétrica com o mercado em que estão inseridas, parecem ter grande influência sobre as particularidades encontradas neste universo de estudo: o tamanho reduzido enfatiza a influência do seu dirigente e formata as características organizacionais, ao passo que a relação assimétrica com o ambiente determina as decisões e estratégias, geralmente reativas às oportunidades, limitações e exigências apresentadas (JULIEN, 1997; LEONE, 1999; CÊRA; ESCRIVÃO FILHO, 2003; TORRES, 2004).

Com efeito, Julien (1997) identificou quatro critérios para formação de tipologias básicas a partir de uma revisão da literatura:

i) origem da propriedade (com ênfase na figura do empreendedor);

ii) organização, estratégia ou potencial de desenvolvimento (com ênfase no tamanho e na estrutura da empresa);

iii) evolução, crescimento pretendido e nível de desenvolvimento da empresa (segundo a teoria de ciclo de vida das empresas) e

iv) setor ou tipo de mercado em que a empresa está inserida (com ênfase na importância do ambiente e das oportunidades de mercado). 


\subsection{As Empresas de Base Tecnológica}

"Empresas de base tecnológica são aquelas que se caracterizam por incorporar o conhecimento científico-tecnológico como seu principal insumo de produção e por relacionarem-se entre si e com a universidade ou instituto de pesquisa" (PERUSSI, 2006; p. 82). Ou seja, as empresas de base tecnológica são aquelas que se apoiam em tecnologias e teorias científicas recentes para gerar novas tecnologias, produtos, serviços e oportunidades de negócios (GRANSTRAND, 1998; STOREY e TETHER, 1998; SÁENZ e CAPOTE, 2002).

Sua importância pode ser discutida em vários aspectos, seja sua capacidade de criar novos empregos, seja sua capacidade de revitalizar economias com problemas, seja por sua contribuição em impostos ou no nível de exportações de um país ou, finalmente, seja ainda pela criação de novas tecnologias (BOLLINGER et al, 1982; GRANSTRAND, 1998). Outra característica que as diferencia é a composição do capital: em muitos casos são financiadas por fontes específicas de fomento à inovação ou à formação de polos tecnológicos (PERUSSI, 2006).

Os empreendedores das empresas de base tecnológica também possuem algumas características distintas:

i) possuem uma herança empreendedora forte, em muitos casos sendo filhos de empreendedores;

ii) possuem um grau de educação avançado, na maioria das vezes sendo mestres ou doutores em engenharia;

iii) são jovens (na casa dos 30 anos);

iv) têm um histórico de desenvolvimento e não apenas de pesquisa;

v) possuem uma enorme necessidade de atingir suas metas, um traço comum à maioria dos empreendedores (GRANSTRAND, 1998; PERUSSI, 2006).

\subsubsection{Pequenas Empresas de Base Tecnológica}

Duas questões precisam ser discutidas, entretanto, em relação ao crescimento das empresas de base tecnológica: a capacidade administrativa e a diversidade tecnológica. As pequenas empresas de base tecnológica geralmente não possuem mecanismos administrativos ou de gestão bem desenvolvidos, dado o seu foco técnico, sendo muito semelhantes às pequenas empresas em geral nesse sentido (JULIEN, 1997; PERUSSI, 2006). Outra característica sua é serem fortemente especializadas em uma tecnologia ou teoria científica 
(PERUSSI, 2006). Combinados, a "organização interna relaxada" (BOLLINGER et al, 1982) e a especialidade tecnológica, por um lado, favorecem a inovação e a dinamização de mercados (BOLLINGER et al, 1982). Por outro lado, EBT maiores tendem diversificar suas tecnologias, o que é um fator crítico para seu crescimento e para a diversificação de produtos, e possuem estruturas gerenciais mais complexas e organizadas, o que cria economias:

i) de escala estáticas: a exploração de uma tecnologia em várias aplicações reduz o custo marginal da tecnologia por aplicação adicional;

ii) de escala dinâmicas: a tecnologia e o conhecimento não se esvaem quando utilizados, mas servem de insumo para o desenvolvimento de novas tecnologias e conhecimentos ao longo do tempo;

iii) de escopo: a diversificação de tecnologias tende a criar seu uso cruzado, ou seja, várias tecnologias se misturam e criam mais tecnologias em novas aplicações;

iv) de velocidade: a transferência de tecnologia, na presença de mecanismos eficientes de coordenação, é mais rápida dentro das empresas do que entre uma empresa e outra. Assim, os diferentes cruzamentos e aplicações tecnológicas descritos nas economias de escala e de escopo ocorrem mais rapidamente em empresas maiores, com uma estrutura administrativa mais desenvolvida (GRANSTRAND, 1998).

Bollinger et al (1982) descrevem fatores que parecem possuir fundamental importância para as PEBT, ajudando-as a combater suas limitações administrativas e tecnológicas:

v) a composição societária, com dois a cinco fundadores sendo o número mais comum;

vi) o alto grau de transferência tecnológica realizada pelos fundadores, seja pela sua formação, seja pelo seu último emprego;

vii) a contratação de pessoas especializadas em administração e em marketing;

viii) o cuidado com as questões relativas à gestão de recursos humanos.

\subsection{O Modelo de Especificidades das Pequenas Empresas}

O Grupo de Estudos Organizacionais da Pequena Empresa (GEOPE) vêm propondo, há mais de uma década, a construção de uma "teoria administrativa" para as pequenas 
empresas, baseada nos "condicionantes que podem ser responsáveis pelo surgimento de algumas particularidades importantes na gestão da pequena empresa" (CÊRA; ESCRIVÃO FILHO, 2003, p. 797): os fatores ambientais, as características individuais do dirigente e as limitações organizacionais (recursos e estrutura). A trajetória e a sobrevivência das pequenas empresas dependem de como estes condicionantes definem as particularidades de cada empresa, impondo necessidades específicas de gestão.

A revisão teórica revelou várias tentativas de caracterizar as pequenas empresas em relação às suas particulares ou condicionantes. Tais caracterizações podem ser agrupadas de acordo com as três dimensões (ou especificidades) propostas pelo GEOPE:

i) o dirigente, figura onipotente, de grande influência pessoal, que cria identidade entre pessoa física e jurídica e a simbiose entre patrimônio social e patrimônio pessoal. A dominação hierárquica do dirigente ocorre justamente porque ele está em contato próximo (social e geograficamente) com os demais membros da organização.

ii) o ambiente, que impõe a concorrência desigual com as grandes empresas, apresenta clientes e fornecedores com grande poder de barganha, resultando em pouco ou nenhum poder de influência perante as imposições e mudanças do macroambiente. $\mathrm{O}$ mercado está muito próximo, tanto geográfica quanto psicologicamente, aumentando a importância do aspecto relacional (direto e informal) da transmissão de informações (em detrimento do aspecto organizacional, formalizado).

Este aspecto relacional faz com que a tomada de decisões seja eminentemente reativa, seguindo um ciclo de intuição-decisão-ação que se retroalimenta pela proximidade entre o dirigente e os principais atores do ambiente.

iii) a organização, de estrutura organizacional informal e simplificada, com acesso a recursos escassos e pouca especialização de funções e conduzida por uma estratégia intuitiva ou pouco formalizada, baseada em um sistema de informações simplificado e orientada por uma racionalidade substantiva (econômica, política e familiar).

A configuração espacial das empresas é compacta, o que significa que o dirigente e os demais membros estão em constante contato uns com os outros e com os vários problemas que surgem. Isso aumenta a versatilidade individual e facilita a supervisão direta e o ajuste mútuo, além de criar uma preferência pela comunicação verbal e não formalizada (JULIEN, 1997; LEONE, 1999; CÊRA; ESCRIVÃO FILHO, 2003; TEIXEIRA, 2003; TORRES, 2004).

A Figura 4.1 sintetiza o modelo utilizado para organizar a revisão bibliográfica: 


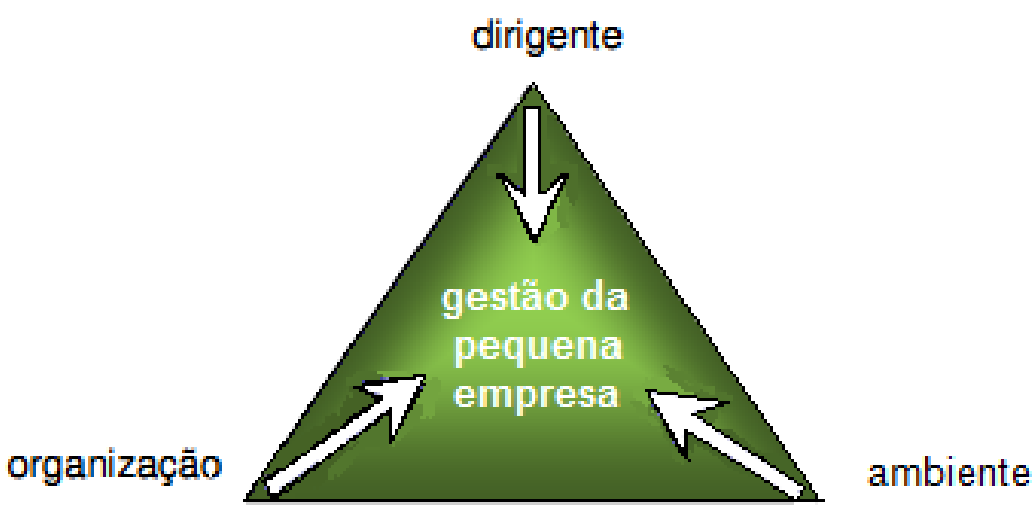

Figura 4.1 - Modelo de especificidades da pequena empresa

Fonte: adaptada de Terence (2008)

O Quadro 4.2, na próxima página, resume as principais caracterizações encontradas na literatura. A partir da análise das características apontadas pelos principais trabalhos sobre o assunto, suas semelhanças e divergências, foi possível criar um mapa mental da realidade da pequena empresa que foi posteriormente aplicado ao mapa conceitual de aprendizagem organizacional. 
Quadro 4.2 - Especificidades de gestão das pequenas empresas

\begin{tabular}{|c|c|c|c|c|c|c|}
\hline \multicolumn{2}{|c|}{$\begin{array}{l}\text { Espe- Autor } \\
\text { cificidades }\end{array}$} & (Leone, 1999) & $\begin{array}{c}\text { (Cêra e Escrivão } \\
\text { Filho, 2003) }\end{array}$ & $\begin{array}{c}\text { (JACYNTHO apud } \\
\text { Teixeira, 2003) }\end{array}$ & (Julien, 1997) & (Torres, 2004) \\
\hline \multirow{6}{*}{ 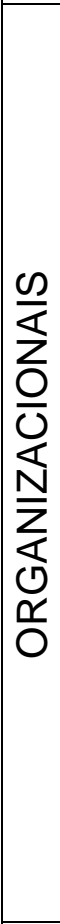 } & \multirow[b]{2}{*}{ Estrutura } & gestão centralizada & 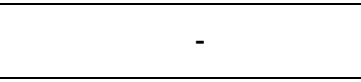 & $\begin{array}{l}\text { dirigida pessoalmente por } \\
\text { seus proprietários }\end{array}$ & centralização da gestão & proximidade hierárquica \\
\hline & & $\begin{array}{l}\text { estrutura } \\
\text { simples e leve } \\
\text { fraca maturidade } \\
\text { organizacional }\end{array}$ & $\begin{array}{l}\text { estrutura organizacional } \\
\text { informal } \\
\text { estrutura organizacional } \\
\text { reduzida }\end{array}$ & $\begin{array}{l}\text { reduzido quadro de } \\
\text { pessoal }\end{array}$ & tamanho (pequeno) & $\begin{array}{l}\text { proximidade de } \\
\text { coordenação }\end{array}$ \\
\hline & $\begin{array}{l}\text { Comporta- } \\
\text { mento }\end{array}$ & fraca especialização & $\begin{array}{l}\text { falta de pessoal } \\
\text { qualificado }\end{array}$ & & pouca especialização & $\begin{array}{l}\text { proximidade intra- } \\
\text { funcional }\end{array}$ \\
\hline & \multirow[b]{2}{*}{ Tecnologia } & pobreza de recursos & $\begin{array}{l}\text { escassez de recursos } \\
\text { financeiros e materiais }\end{array}$ & $\begin{array}{l}\text { não dispor de elevados } \\
\text { recursos econômicos }\end{array}$ & 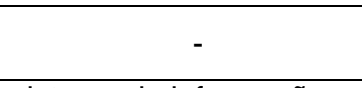 & - \\
\hline & & $\begin{array}{l}\text { sistema de informações } \\
\text { simples } \\
\text { inexistência de dados } \\
\text { quantitativos }\end{array}$ & 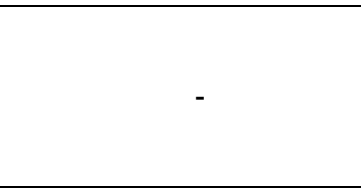 & 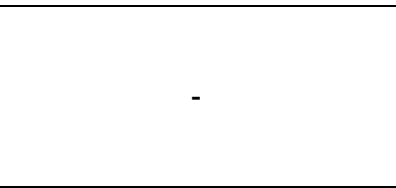 & $\begin{array}{l}\text { sistema de informação } \\
\text { interno pouco complexo } \\
\text { ou pouco organizado } \\
\text { sistema de informação } \\
\text { externa simples }\end{array}$ & $\begin{array}{l}\text { proximidade do sistema de } \\
\text { informação interno } \\
\text { proximidade do sistema de } \\
\text { informação externo }\end{array}$ \\
\hline & Estratégia & $\begin{array}{l}\text { ausência da atividade de } \\
\text { planejamento formal } \\
\text { estratégia intuitiva e pouco } \\
\text { formalizada } \\
\text { alto grau de autonomia } \\
\text { decisional } \\
\text { horizonte temporal de } \\
\text { curto prazo } \\
\text { racionalidades econômica, } \\
\text { política e familiar }\end{array}$ & $\begin{array}{l}\text { estratégia Informal } \\
\text { não utilização de } \\
\text { instrumentos } \\
\text { administrativos formais }\end{array}$ & - & $\begin{array}{l}\text { estratégia intuitiva ou } \\
\text { pouco formalizada }\end{array}$ & proximidade temporal \\
\hline \multirow{2}{*}{\multicolumn{2}{|c|}{ 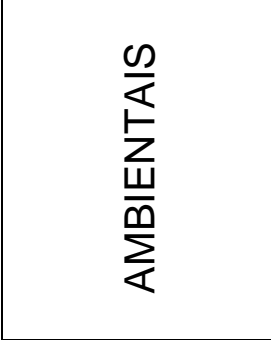 }} & $\begin{array}{l}\text { ter reduzido valor de } \\
\text { capital e de } \\
\text { faturamento anual em } \\
\text { relação ao setor } \\
\text { econômico onde opera }\end{array}$ & $\begin{array}{l}\text { fraqueza das partes do } \\
\text { mercado }\end{array}$ & $\begin{array}{l}\text { concorrência desigual com } \\
\text { as grandes empresas } \\
\text { clientes e fornecedores } \\
\text { com grande poder de } \\
\text { barganha }\end{array}$ & - & - \\
\hline & & $\begin{array}{l}\text { não ocupar posição } \\
\text { dominante em seu setor }\end{array}$ & $\begin{array}{l}\text { situação extra- } \\
\text { organizacional } \\
\text { incontrolável }\end{array}$ & $\begin{array}{l}\text { pouco ou nenhum poder } \\
\text { de influência perante as } \\
\text { imposições e mudanças } \\
\text { do macroambiente }\end{array}$ & - & - \\
\hline
\end{tabular}


Quadro 4.2 - Especificidades de gestão das pequenas empresas (continuação)

\begin{tabular}{|c|c|c|c|c|c|}
\hline $\begin{array}{l}\text { Autor } \\
\text { cificidades }\end{array}$ & (Leone, 1999) & $\begin{array}{c}\text { (Cêra e Escrivão } \\
\text { Filho, 2003) }\end{array}$ & $\begin{array}{c}\text { (JACYNTHO apud } \\
\text { Teixeira, 2003) }\end{array}$ & (Julien, 1997) & (Torres, 2004) \\
\hline \multirow{4}{*}{ 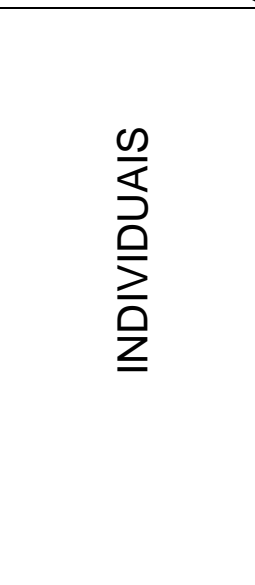 } & $\begin{array}{l}\text { identidade entre pessoa } \\
\text { física e jurídica } \\
\text { simbiose entre patrimônio } \\
\text { social e patrimônio } \\
\text { pessoal } \\
\text { propriedade dos capitais }\end{array}$ & - & $\begin{array}{l}\text { não estar direta ou } \\
\text { indiretamente vinculada } \\
\text { aos grandes grupos } \\
\text { financeiros e ser } \\
\text { juridicamente } \\
\text { independente de outras } \\
\text { grandes empresas }\end{array}$ & - & - \\
\hline & $\begin{array}{l}\text { influência pessoal do } \\
\text { proprietário-dirigente }\end{array}$ & $\begin{array}{l}\text { informalidade no } \\
\text { relacionamento }\end{array}$ & 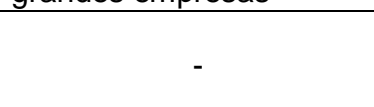 & - & - \\
\hline & $\begin{array}{l}\text { onipotência do } \\
\text { proprietário-dirigente } \\
\text { propensão a riscos } \\
\text { calculados }\end{array}$ & - & - & - & - \\
\hline & $\begin{array}{l}\text { dependência ante certos } \\
\text { empregados }\end{array}$ & $\begin{array}{l}\text { falta de habilidade na } \\
\text { gestão do tempo }\end{array}$ & - & - & - \\
\hline
\end{tabular}




\subsection{Aprendizagem Organizacional nas Pequenas Empresas}

“A pequena empresa possui muitas das características de uma organização de negócios que aprende efetivamente" (GIBB apud ZHANG, MACPHERSON e JONES, 2006, p. 301). Realmente, a estrutura menos hierárquica, a maior flexibilidade na tomada de decisões, a menor burocracia, o contato pessoal mais intenso entre seus membros e a proximidade com o mercado facilitam os processos de aquisição e distribuição da informação (socialização e externalização). Por outro lado, entretanto, o baixo grau de formalização, o pior nível de escolaridade de seus membros, a estrutura precária de comunicação e a limitação de recursos (que determinam um certo imediatismo na tomada de decisões) dificultam os processos de interpretação da informação e memória organizacional (combinação e externalização) (HUBER, 1991; NONAKA, 1991; DEAKINS; FREEL, 1998; STEWART JR et al., 1999; GARCÍA-MORALES; LLORÉNS-MONTES; VERDÚ-JOVER, 2007).

Assim, ao considerar a aprendizagem organizacional nas pequenas empresas, é preciso examinar, antes de mais nada, suas especificidades de gestão características, pois terão um impacto importante sobre a capacidade de aprender da empresa.

\subsubsection{O Papel do Dirigente}

A maior parte da literatura relacionada à aprendizagem organizacional nas pequenas empresas caracteriza a figura do dirigente como seu principal fator de influência.

\footnotetext{
"Para que as pequenas empresas cresçam é necessário que os empreendedores sejam capazes de aprender com as suas decisões, seus erros, suas experiências e suas redes de contatos. (...) A habilidade dos empreendedores para maximizar conhecimento como resultado da experiência de eventos de aprendizagem determinará o grau de sucesso que sua empresa irá atingir" (DEAKINS; FREEL, 1998, p. 153).
}

Dada a característica centralizadora e a proximidade hierárquica associadas ao dirigente das pequenas empresas, suas características pessoais determinarão os tipos de comportamentos que são esperados e apoiados, e, consequentemente, definirão a existência de processos de aprendizagem de laço único ou duplo (DEAKINS; FREEL, 1998). Esta relação entre as características pessoais do dirigente e a capacidade de aprendizagem das empresas é 
tão importante que Zhang, Macpherson e Jones (2006) definiram duas categorias de empresas com base nesse critério: as empresas voltadas à estabilidade (cujos dirigentes possuem um foco mais internalizado e promovem a aprendizagem por experiência, concentrada em indivíduos ou grupos pequenos) e as empresas voltadas à inovação (cujos dirigentes possuem um foco mais externo e promovem a aprendizagem "mais profunda e mais abrangente"). Os dirigentes das empresas voltadas à inovação se aproveitaram de incidentes críticos para encorajar a aprendizagem através da introdução de novos produtos, processos e relacionamentos externos. A aprendizagem das empresas voltadas à estabilidade, por outro lado, tem caráter geralmente reativo. Os dirigentes não se comprometem com mudanças mais profundas que afetem as normas da organização ou o relacionamento com clientes e fornecedores. "Os dirigentes devem estar dispostos a renunciar a um certo controle proprietário para promover a aprendizagem organizacional genuína" (ZHANG, MACPHERSON e JONES, 2006, p.312).

Entre as características pessoais mais importantes para a aprendizagem organizacional destacam-se a habilidade para formação de redes (networking) já nos estágios iniciais da empresa, assimilação de experiências e oportunidades, capacidade de reflexão sobre estratégias passadas, reconhecimento de erros, capacidade de acessar recursos e trazer membros externos para o "time de empreendedores" (ZHANG, MACPHERSON e JONES, 2006).

\subsubsection{O Papel do Ambiente}

O ambiente age como fonte de informação e deflagrador da aprendizagem organizacional. A natureza dinâmica do ambiente externo, aliada ao seu poder de seleção (competição), faz com que as pequenas empresas precisem aprender constantemente para assegurar sua adaptação ao mercado. As mudanças organizacionais nas pequenas empresas decorrem mais da combinação de conhecimento e reação a eventos críticos do que como resultado de um desenvolvimento planejado (DEAKINS; FREEL, 1998; ZHANG, MACPHERSON e JONES, 2006).

A troca de informações com o ambiente prioriza a utilização de canais ricos, informais e acessíveis, sendo muitas vezes confiada a algumas pessoas "com contatos" (não necessariamente dirigentes) e altamente dependente de trocas verbais e não formalizadas. As informações recebidas podem promover a aprendizagem por imitação (através da observação das organizações bem-sucedidas e da adoção de suas práticas) ou por tentativa e erro (através 
percepção da posição estratégica da empresa depois da adoção de novas práticas) (LANG; CALANTONE; GUDMUNDSON, 1997; DEAKINS; FREEL, 1998).

Assim como nas grandes empresas, a troca de informações com o ambiente se intensifica em momentos de percepção de riscos ou de oportunidades. Em momentos de risco, entretanto, as pequenas empresas possuem uma fragilidade de acesso a informações confiáveis. Estudos de padrões de busca de informação nas grandes empresas demonstraram que estas tendem a valorizar mais as trocas com fontes externas de informação em momentos de maior oportunidade, e a valorizar mais as informações internas em momentos de risco ou crise, já que estas são mais confiáveis, familiares e acessíveis. As pequenas empresas, entretanto, não possuem recursos suficientes para apoiarem-se apenas em informações internas. Essa fragilidade é especialmente importante porque tem um impacto na sobrevivência das pequenas empresas: enquanto que a perda de uma oportunidade pode prejudicar a empresa, a inabilidade de responder adequadamente a um risco ou a uma crise pode ser fatal. Nesse caso, a sobrevivência das pequenas empresas pode estar diretamente relacionada à sua capacidade de identificar e acessar fontes de informação externas confiáveis (LANG; CALANTONE; GUDMUNDSON, 1997).

Os momentos de crise também funcionam como deflagradores de aprendizagem, legitimizando a inovação, a mudança e a adaptação. As mudanças no ambiente alteram a situação da empresa e estimulam a busca por novas informações. Mudanças mais extremas, ou "eventos de aprendizagem descontínua" promovem o "deslocamento de uma adaptação incremental para a aprendizagem organizacional de "maior nível", causando mudanças fundamentais em premissas e atividades" (ZHANG, MACPHERSON e JONES, 2006, p.304).

\subsubsection{O Papel da Organização}

Ao contrário das grandes empresas, as pequenas empresas geralmente não se preocupam com (ou não possuem recursos para) o desenvolvimento de seus membros, o que diminui a motivação e aumenta a rotatividade. Há menos oportunidades para treinamento e desenvolvimento de carreira, além de maior pressão para demonstrar que o investimento em desenvolvimento de pessoal (não só de recursos, como também de tempo) têm um impacto positivo sobre o desempenho da empresa. Assim, enquanto as grandes organizações apóiamse em suas vantagens materiais (por exemplo, economias de escala, recursos financeiros e tecnológicos) para garantir o aprendizado, as pequenas empresas geralmente exibem vantagens comportamentais (dinamismo empreendedor, flexibilidade, eficiência, proximidade 
com o mercado, motivação) (GARCÍA-MORALES; LLORÉNS-MONTES; VERDÚJOVER, 2007).

Cinco características organizacionais são consideradas as mais importantes para a aprendizagem organizacional: capacidade de adaptação, capacidade de planejamento, grau de informação e conhecimento, desenvolvimento de recursos humanos e capacidade de crescimento (ZHANG, MACPHERSON e JONES, 2006).

\subsection{Um Modelo de Aprendizagem Organizacional nas Pequenas Empresas}

Apesar de reconhecer as influências e características individuais do dirigente, do ambiente e da organização sobre a aprendizagem organizacional, os modelos propostos para as pequenas empresas tendem a salientar a importância da inter-relação entre as especificidades sobre o processo. As características do dirigente influenciam diretamente as características organizacionais, que por sua vez são fortemente dependentes do ambiente em que a pequena empresa está inserida. Assim, “a aprendizagem em pequenas empresas só pode ser compreendida em termos de seu contexto organizacional e do papel influenciador do dirigente em sua tentativa de imbuir sua aprendizagem empreendedora na organização que está gerindo" (ZHANG, MACPHERSON e JONES, 2006).

A Figura 4.2, abaixo, ilustra o modelo:

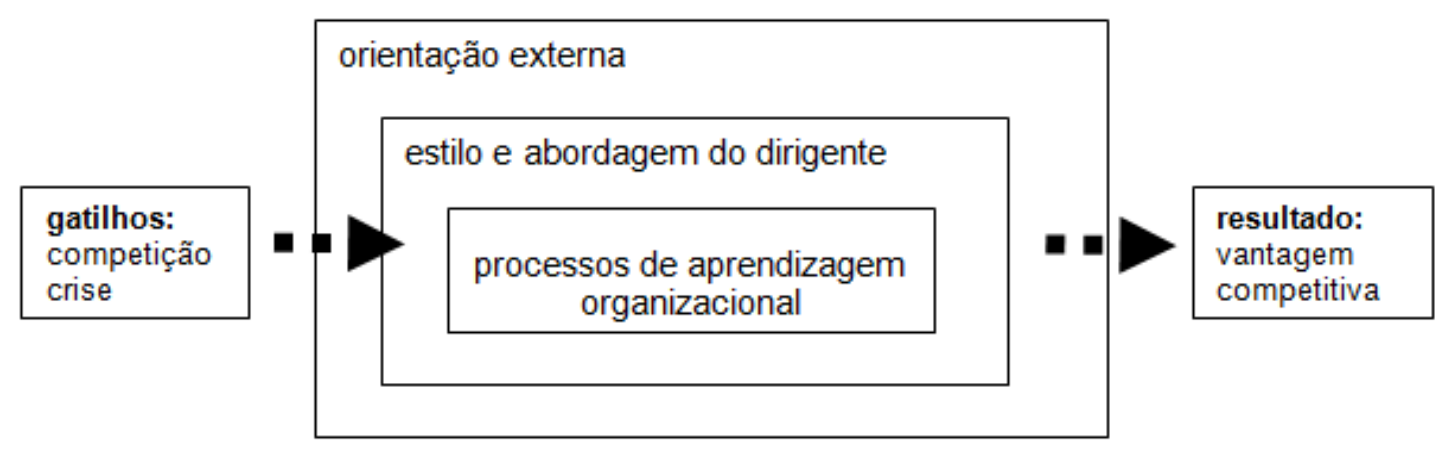

Figura 4.2 - Modelo de aprendizagem da pequena empresa

Fonte: adaptado de Zhang, Macpherson e Jones (2006) 


\section{Métodos de Pesquisa}

Esse capítulo descreve primeiramente os métodos utilizados para realizar a busca sistemática sobre os temas "aprendizagem organizacional" e "aprendizagem organizacional na pequena empresa". A revisão teórica decorrente dessa busca sistemática foi apresentada nos Capítulos 2 e 4. Subsequentemente é apresentada a descrição dos métodos empregados na pesquisa de campo, incluindo a formação do mapa conceitual que foi levado a campo para verificação, referente à aprendizagem organizacional na pequena empresa.

\subsection{Relato da Busca Sistemática}

Seria interessante que os textos selecionados para o estado da arte fossem os mais relevantes sobre o assunto disponíveis. O conceito de relevância, por sua vez, é derivado do número de vezes em que o determinado artigo foi citado (o que indica interesse pela comunidade científica) e o fator de importância do periódico em que foi publicado (uma indicação de seu rigor técnico e científico). Além disso, é importante que a pesquisa aborde as mais diversas fontes de publicação. Dessa forma, a busca pelos textos mais relevantes foi efetuada através do Google Acadêmico (que não restringe os resultados obtidos em função de licenças de editoras e é considerado, portanto, o mecanismo de busca mais "democrático" entre os disponíveis). Por fim, espera-se que os resultados obtidos indiquem as tendências e tópicos mais relevantes ao longo do tempo. Assim, a busca avançada do Google Acadêmico foi empregada com o preenchimento do campo "com a frase exata" com as palavras-chaves escolhidas e restrição de data em 5 grupos específicos: artigos publicados entre 1960 e 1980, entre 1981 e 1990, entre 1991 e 2000, entre 2001 e 2005, entre 2006 e 2010 e desde 2010.

A Tabela 5.1 mostra o número de artigos encontrados para cada palavra-chave relacionada ao tema geral "Aprendizagem Organizacional", demonstrando o crescente interesse pelo assunto, tanto nacional quanto internacionalmente:

Tabela 5.1 - Resultados para o tema geral "Aprendizagem Organizacional"

\begin{tabular}{lcccccc} 
Palavra-chave & $\begin{array}{c}\mathbf{1 9 6 0 -} \\
\mathbf{1 9 8 0}\end{array}$ & $\mathbf{1 9 8 1 - \mathbf { 1 9 9 0 }}$ & $\mathbf{1 9 9 1 - \mathbf { 2 0 0 0 }}$ & $\mathbf{2 0 0 1 - 2 0 0 5}$ & $\mathbf{2 0 0 6 - 2 0 0 9}$ & $\begin{array}{c}\text { Desde } \\
\mathbf{2 0 1 0}\end{array}$ \\
\hline organizational learning & 553 & 1.590 & 16.200 & $\mathbf{2 2 . 4 0 0}$ & 18.500 & 10.400 \\
\hline learning organizations & 52 & 100 & 5.200 & 7.150 & 6.870 & 2.000 \\
\hline knowledge creation & 201 & 1.100 & 7.440 & 17.700 & 17.300 & 8.930 \\
\hline aprendizagem org. & 0 & 11 & 211 & 872 & 1.360 & 556 \\
\hline org. de aprendizagem & 0 & 0 & 55 & 149 & 175 & 71
\end{tabular}


O tema particular "Aprendizagem Organizacional nas Pequenas Empresas" foi pesquisado através da combinação de palavras-chave, com a utilização do operador lógico “AND" no campo "com a frase exata". Além disso, uma outra restrição teve que ser utilizada: o campo "onde minhas palavras ocorrem" foi definido como "no título do artigo". Isso foi necessário porque, ao contrário do que ocorreu com o tema geral, muitos artigos que continham as palavra-chave escolhidas não tratavam exatamente das pequenas empresas (muitos apenas empregaram pequenas empresas como amostra de estudo pela facilidade metodológica, sem a intenção de discutir o assunto propriamente dito). A presença de palavras-chave relacionadas à pequena empresa no título provou ser um bom indicativo de que o artigo tratava diretamente da teoria da pequena empresa. A Tabela 5.2 mostra o número de artigos encontrados, demonstrando que, embora haja um crescente interesse pelo assunto, o tema ainda não foi bem explorado. As publicações brasileiras não retornaram nenhum artigo (foram encontradas apenas citações), evidenciando a lacuna teórica:

Tabela 5.2 - Resultados para o tema particular "A. O. nas Pequenas Empresas"

\begin{tabular}{|c|c|c|c|c|c|c|c|}
\hline $\begin{array}{l}\text { Palavras-chave } \\
\text { (com o operador "Al }\end{array}$ & D") & $\begin{array}{l}1960 \text { - } \\
1980\end{array}$ & $\begin{array}{l}1981 \text { - } \\
1990\end{array}$ & $\begin{array}{l}1991 \text { - } \\
2000\end{array}$ & $\begin{array}{l}2001 \text { - } \\
2005\end{array}$ & $\begin{array}{l}2006- \\
2009\end{array}$ & $\begin{array}{l}\text { desde } \\
2010\end{array}$ \\
\hline & & Númerc & citações & & & & \\
\hline & small business & 0 & 0 & 0 & 0 & 7 & 0 \\
\hline & small enterprises & 0 & 0 & 0 & 2 & 8 & 2 \\
\hline & small enterprise & 0 & 0 & 0 & 0 & 2 & 0 \\
\hline $\begin{array}{l}\text { organizational } \\
\text { learning + }\end{array}$ & small firms & 0 & 0 & 3 & 7 & 1 & 0 \\
\hline & small firm & 0 & 0 & 3 & 1 & 1 & 0 \\
\hline & SMEs & 0 & 0 & 4 & 5 & 12 & 0 \\
\hline & SME & 0 & 0 & 1 & 0 & 4 & 0 \\
\hline & small business & 0 & 0 & 0 & 0 & 0 & 0 \\
\hline & small enterprises & 0 & 0 & 0 & 0 & 0 & 0 \\
\hline & small enterprise & 0 & 0 & 0 & 0 & 0 & 1 \\
\hline $\begin{array}{l}\text { knowledge creation } \\
+\end{array}$ & small firms & 0 & 0 & 5 & 2 & 1 & 0 \\
\hline & small firm & 0 & 0 & 0 & 2 & 2 & 0 \\
\hline & SMEs & 0 & 0 & 2 & 0 & 6 & 1 \\
\hline & SME & 0 & 0 & 0 & 0 & 1 & 0 \\
\hline & pequenas empresas & 0 & 0 & 1 & 1 & 0 & 0 \\
\hline $\begin{array}{l}\text { aprendizagem } \\
\text { oraanizacional + }\end{array}$ & pequena empresa & 0 & 0 & 0 & 0 & 0 & 0 \\
\hline & PMEs & 0 & 0 & 0 & 0 & 0 & 0 \\
\hline & PME & 0 & 0 & 0 & 0 & 0 & 0 \\
\hline
\end{tabular}

Como o tema particular retornou um número pequeno de resultados, todos os itens foram analisados e foram selecionados todos os artigos que contivessem pelo menos uma 
citação. Já o tema geral retornou um número grande demais. Assim, para cada palavra-chave definida foram analisados e filtrados os 50 primeiros resultados retornados pela busca. $\mathrm{O}$ primeiro parâmetro aplicado como filtro foi o número de citações do artigo. O objetivo era encontrar os artigos mais citados para cada tópico pesquisado. A seguir foi criada uma planilha contendo os dados principais de todos os artigos que atendessem aos critérios acima: autores, fonte, ano de publicação, título e hiperlink para os dados do artigo.

O segundo parâmetro aplicado como filtro foi a importância da fonte da publicação. Para isso foram adicionadas 2 colunas à planilha criada anteriormente, que receberam dados do JCR (Journal Citation Reports) da base de dados ISI Web of Knowledge. Os dados anotados para cada fonte foram o "Importance Factor" (que indica a importância da fonte no último ano) e o "5 Year Importance Factor" (que indica a importância da fonte nos últimos 5 anos). A seguir foi tirada a média entre os dois fatores (para que a tendência - aumento ou redução de importância - fosse melhor refletida). Finalmente uma última coluna foi adicionada: o "Coeficiente de Relevância", resultado da multiplicação da média dos fatores de importância e do número de citações recebidas em cada artigo. Os Anexos A, B e C contém as planilhas criadas para o tema pesquisado e ilustram os índices utilizados em cada etapa.

Para evitar coeficientes de relevância iguais a zero (já que qualquer dos dois critérios adotados, com valor zero, anularia o outro critério) os artigos que não foram citados receberam o valor de 0,01 na coluna contendo o número de citações e os periódicos que não foram avaliados pelo JCR receberam o valor 0,03. Teses e dissertações receberam o valor 0,02 e trabalhos de seminários e congressos receberam o valor 0,01 .

Para as publicações nacionais foi utilizada a classificação "Web Qualis" da CAPES. Os periódicos de nota A1 receberam um índice numérico correspondente de 7, os periódicos de nota $\mathrm{A} 2$ receberam o índice 6 , os periódicos $\mathrm{B} 1$ receberam o índice 5 e assim por diante. Os periódicos não avaliados receberam o índice 0,1 . Da mesma forma, as teses e dissertações receberam a nota equivalente à avaliação de seu programa pela CAPES. Da mesma forma que para os artigos internacionais, foram multiplicados o número de citações (o valor zero foi substituído por 0,1 ) e o índice atribuído à fonte. É importante salientar, aqui, que os coeficientes de relevância encontrados para os artigos internacionais e para os artigos nacionais não são diretamente comparáveis, já que os critérios numéricos aplicados para a obtenção dos coeficientes não foram os mesmos (e não possuem a mesma ordem de grandeza).

Foram geradas assim três base de dados (em planilha do Excel) com os dados de relevância do artigo e do periódico, dados dos autores e data de publicação e indicações para 
obtenção do artigo original, uma para o tema geral, Aprendizagem Organizacional (contendo 131 artigos no total, 84 de produção internacional e 47 de produção nacional) e outra para o tema particular, Aprendizagem organizacional nas Pequenas empresas (contendo 66 artigos no total) que depois serviram de base para a pesquisa do estado da arte através da seleção dos artigos escritos desde 2000. Os artigos escritos antes de 2000 foram utilizados como leitura complementar, mas não necessariamente utilizados neste trabalho.

\subsection{Proposição de um Mapa Conceitual para investigar a Aprendizagem} Organizacional na Pequena Empresa

O desenvolvimento subsequente dos construtos de aprendizagem horizontal e aprendizagem vertical apresentados no Capítulo 3 é a sua discussão no âmbito das pequenas empresas, considerando-se as especificidades apresentadas no Capítulo 4. O Quadro 5.1, abaixo, reproduz o Quadro 3.2, relembrando como os construtos foram desenvolvidos:

Quadro 5.1 - Formação visual dos construtos de aprendizagem horizontal e vertical

\begin{tabular}{|c|c|c|}
\hline Componente & Aprendizagem Vertical & Aprendizagem Horizontal \\
\hline Tipo de Aprendizagem & Adaptativa & Generativa \\
\hline Hierarquia & Estrutura mais hierarouizada & Estrutura pouco hierárquica, \\
\hline Especialização & Especializaçào técnica & $\begin{array}{c}\text { Multidisciplinaridade, trabalho em } \\
\text { equipe } \\
\end{array}$ \\
\hline Centralização & Alta, raciocinio linear & $\begin{array}{c}\text { Baixa, raciocinio sistèmico } \\
\square\end{array}$ \\
\hline Tamanho (integração) & $\begin{array}{l}\text { Grupos isolados, pouca } \\
\text { integraçás }\end{array}$ & $\begin{array}{l}\text { Grupos inter-relacionados, muita } \\
\text { integraçáo }\end{array}$ \\
\hline
\end{tabular}


Quadro 5.1 - Formação visual dos construtos de aprendizagem horizontal e vertical (continuação)

\begin{tabular}{|l|c|c|}
\hline \multicolumn{1}{|c|}{ Componente } & Aprendizagem Vertical & Aprendizagem Horizontal \\
\hline Estratégia & & \\
\hline Cultura & & \\
\hline Resultado & & \\
\hline Efeito & & \\
\hline
\end{tabular}

É necessário agora reexaminar os componentes estruturais e contextuais de uma organização à luz das especificidades das pequenas empresas:

1) Formalização - é o critério de transferência e absorção de informações. Tipicamente as pequenas empresas possuem um baixo grau de formalização e sistemas de informação simples, tornando a localização de informações e recursos críticos mais difícil (JULIEN, 1997; LEONE, 1999; CÊRA E ESCRIVÃO FILHO, 2003). Os subprocessos de memória organizacional ou de produção de conhecimento explícito deveriam, portanto, se tornar menos frequentes. Por outro lado, a proximidade dos sistemas de informação interno e externo (TORRES, 2004) deveria favorecer o livre fluxo de informações, que promoveria o diagnóstico em profundidade e a "franqueza participativa e reflexiva" de Senge (2001).

2) Especialização e Hierarquia de autoridade - a baixa especialização, a proximidade intrafuncional e a proximidade de coordenação favorecem o raciocínio sistêmico de Senge (1990). Além disso, a estrutura hierárquica já é naturalmente "achatada" e o número reduzido de pessoas cria novas relações e espaços organizacionais (JULIEN, 1997; LEONE, 1999; TORRES, 2004). Por outro lado, a falta de pessoal qualificado (CÊRA E ESCRIVÃO FILHO, 2003) pode afetar o desenvolvimento de atividades mais complexas e os subprocessos de codificação de Nonaka (1990) e de interpretação de Huber (1991). 
3) Centralização - o dirigente costuma ter um papel muito forte na tomada de decisões e pode ser bastante centralizador (JULIEN, 1997; LEONE, 1999). Por outro lado, a informalidade dos relacionamentos, a não utilização de instrumentos administrativos formais característica das pequenas empresas e a proximidade hierárquica (CÊRA E ESCRIVÃO FILHO, 2003) podem significar uma maior liberdade de ação para os demais membros da empresa.

4) Profissionalismo - o investimento em treinamento costuma ser menor do que o das grandes organizações e a mão de obra costuma ser menos qualificada nas pequenas empresas (CÊRA E ESCRIVÃO FILHO, 2003). Por outro lado, a proximidade de coordenação e a proximidade hierárquica (dependendo do grau de centralização que o dirigente impõe à empresa) (TORRES, 2004) facilitam a compreensão de um objetivo comum e o empoderamento pessoal, promovendo também os processos de descobrimento, de questionamento e de reflexão voltados ao autoconhecimento, como prescritos por Senge (1990).

5) Taxas de pessoal - o controle da rotatividade de pessoal é bem mais difícil, graças à restrição de recursos, que resulta em menos oportunidades em relação à remuneração e planos de carreira (LEONE, 1999; CÊRA E ESCRIVÃO FILHO, 2003). Por outro lado, a maior rotatividade de pessoal impede que o código da empresa fique estagnado, propiciando também a contratação de pessoas que aprendem rápido e pessoas que aprendem mais lentamente e gerando, assim, um melhor equilíbrio da taxa de alteração do código da empresa. O quanto a taxa de rotatividade irá influenciar a taxa de alteração do código da empresa dependerá fundamentalmente de duas características das pequenas empresas: a grande influência pessoal do proprietário-dirigente (JULIEN, 1997; LEONE, 1999), que pode priorizar a contratação apenas de pessoas que aprendem rápido e não alteram o código, e a dependência ante certos empregados (LEONE, 1999), que pode criar um outro "núcleo de influência", reduzindo da mesma forma a velocidade de alteração do código.

6) Efeitos do tamanho - a própria característica de proximidade temporal e espacial das pequenas empresas (TORRES, 2004) aumentam a probabilidade de ocorrência da "miopia temporal", ao passo que o tamanho reduzido inibe a "miopia espacial" descritas por Levinthal e March (1993) - ver Capítulo 3.3. Quanto à "miopia do fracasso" (LEVINTHAL; MARCH, 1993), há duas possibilidades: a falta de recursos pode aumentá-la, gerando a postura de "em time que está ganhando não se mexe", 
mas a proximidade com o ambiente e o baixo poder de barganha das pequenas empresas (CÊRA E ESCRIVÃO FILHO, 2003; TORRES, 2004), por outro lado, podem criar uma empresa bem mais ágil e reativa, inibindo a "miopia do fracasso" (LEVINTHAL; MARCH, 1993).

7) Tecnologia organizacional - "a tecnologia organizacional não será um fator definidor para as organizações de aprendizagem, que poderão ser artesanais, orgânicas, burocráticas, assumindo formas variadas, de acordo com a sua necessidade" (LADO; WILSON, 1994; FLEURY; FLEURY, 1995; NEVIS; DIBELLA; GOULD, 1995; BITENCOURT; GONÇALO, 1999; KONTOGHIORGHES; AWBRE; FEURIG, 2005) - ver Capítulo 3.3. Isso também vale para as pequenas empresas.

8) Ambiente - mais do que ser ubíquo à aprendizagem, nas pequenas empresas o ambiente é um forte motor, já que a falta de posição dominante em seu setor leva a uma situação extraorganizacional incontrolável, ou seja, a pouco ou nenhum poder de influência perante as imposições e mudanças do macroambiente (LEONE, 1999; CÊRA E ESCRIVÃO FILHO, 2003; JACYNTHO apud Teixeira, 2003). Sem capacidade para controlar o ambiente à sua volta, as pequenas empresas tornam-se extremamente reativas. Nesse caso espera-se o mesmo que nas grandes organizações: quanto menor o número de competidores, maior a importância do valor do desempenho e quanto maior o número de competidores, maior a importância do valor da variabilidade.

9) Metas e estratégias - a relação de reciprocidade que existe nas grandes organizações é ainda mais estreita nas pequenas empresas: a estratégia assumida (e aqui a figura do dirigente é fundamental) orienta o aprendizado, ao passo que o processo de aprendizagem faz parte da estratégia da empresa, já que esta é construída de maneira intuitiva e pouco formalizada (JULIEN, 1997). Também há um equilíbrio de forças interessante: por um lado a proximidade temporal, i.e., o horizonte temporal de curto prazo, (JULIEN, 1997; TORRES, 2004) tende a inibir estratégias que priorizam a variabilidade, ao passo que a ausência da atividade de planejamento formal e o alto grau de autonomia decisional, aliados ao emprego das racionalidades política e familiar ao processo decisório (JULIEN, 1997; LEONE, 1999), tendem a facilitar a introdução da variabilidade.

10) Cultura - O’Reilly III (1996) e Nonaka (1991) ressaltam a importância do principal dirigente de uma organização em agir como um propagador da "visão 
compartilhada", ou um "guarda-chuva conceitual", gerenciando primariamente a cultura organizacional. Senge (1990) também destaca o papel do dirigente, descrevendo-o como um projetista, um guia e um professor - ver Cap. 3.3. Nas pequenas empresas o dirigente possui um papel ainda mais destacado (JULIEN, 1997; LEONE, 1999) e será fundamental para definir a cultura de sua empresa.

Os novos construtos de aprendizagem organizacional na pequena empresa seriam então construídos com base no exame dessas relações, como mostra o Quadro 5.2.

Quadro 5.2: Aprendizagem vertical e aprendizagem horizontal na pequena empresa

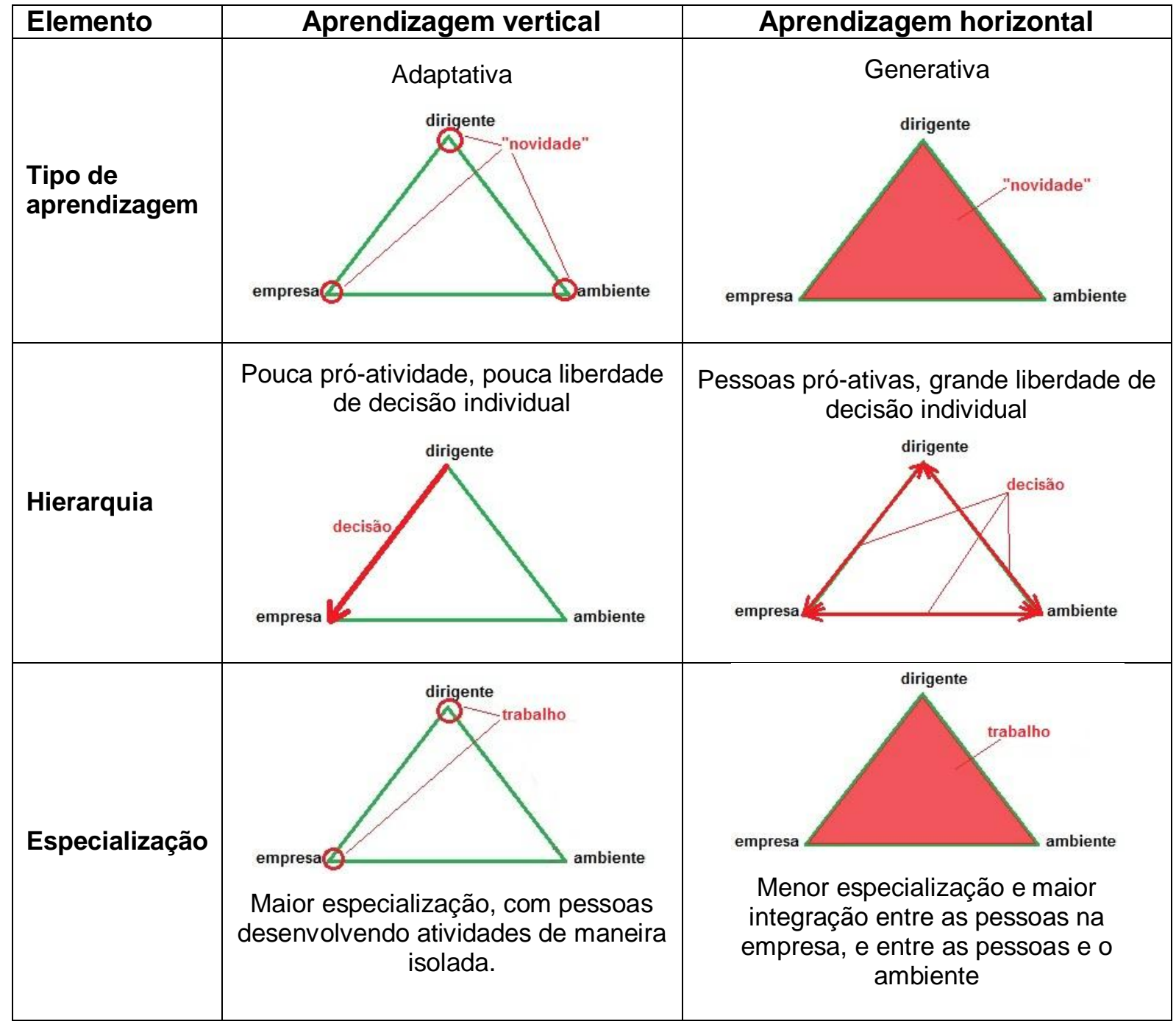


Quadro 5.2: Aprendizagem vertical e aprendizagem horizontal na pequena empresa (continuação)

\begin{tabular}{|c|c|c|}
\hline Elemento & Aprendizagem vertical & Aprendizagem horizontal \\
\hline Centralização & $\begin{array}{l}\text { Alta, as decisões sempre passam pelo } \\
\text { dirigente }\end{array}$ & $\begin{array}{l}\text { Baixa, todos interagem sem } \\
\text { necessariamente passar pelo controle } \\
\text { do dirigente }\end{array}$ \\
\hline $\begin{array}{l}\text { Tamanho } \\
\text { (integração) }\end{array}$ & $\begin{array}{l}\text { Baixa integração, com fluxo controlado } \\
\text { de informações } \\
\text { dirigente }\end{array}$ & $\begin{array}{l}\text { Alta integração, com livre fluxo de } \\
\text { informações } \\
\text { dirigente }\end{array}$ \\
\hline Estratégia & De curto prazo, reativa & $\begin{array}{l}\text { De longo prazo, proativa } \\
\text { dirigente }\end{array}$ \\
\hline Cultura & $\begin{array}{l}\text { Interações de laço único } \\
\text { dirigente } \\
\text { erreção de }\end{array}$ & $\begin{array}{l}\text { Interações de laço duplo } \\
\text { dirigente } \\
\text { correção } \\
\text { de erros }\end{array}$ \\
\hline Resultado & $\begin{array}{c}\text { Adaptação } \\
\text { dirigente }\end{array}$ & $\begin{array}{l}\text { Adaptabilidade } \\
\text { dirigente }\end{array}$ \\
\hline & Oambiente & empresa $\angle$ \\
\hline
\end{tabular}


Quadro 5.2: Aprendizagem vertical e aprendizagem horizontal na pequena empresa (continuação)

\begin{tabular}{|l|c|c|}
\hline Elemento & Aprendizagem vertical & Aprendizagem horizontal \\
\hline \multirow{2}{*}{ Efeito } & & \\
& Localizado & dirigente \\
& empresa & Disseminado em todas as dimensões \\
\hline
\end{tabular}

$\mathrm{O}$ exame das figuras acima mostra que no processo de aprendizagem vertical apenas as dimensões dirigente, empresa ou ambiente são envolvidas, isoladamente, (os "vértices do triângulo") ou em pares (usando uma única "aresta do triângulo"). Já no processo de aprendizagem horizontal as três "arestas do triângulo" estão envolvidas, representando interações em todas as dimensões. Os construtos de aprendizagem horizontal e de aprendizagem vertical podem então ser transpostos, no âmbito das pequenas empresas, para um construto definido pelas quantidade de arestas envolvidas no processo de mudança, como ilustra a Figura 5.1.

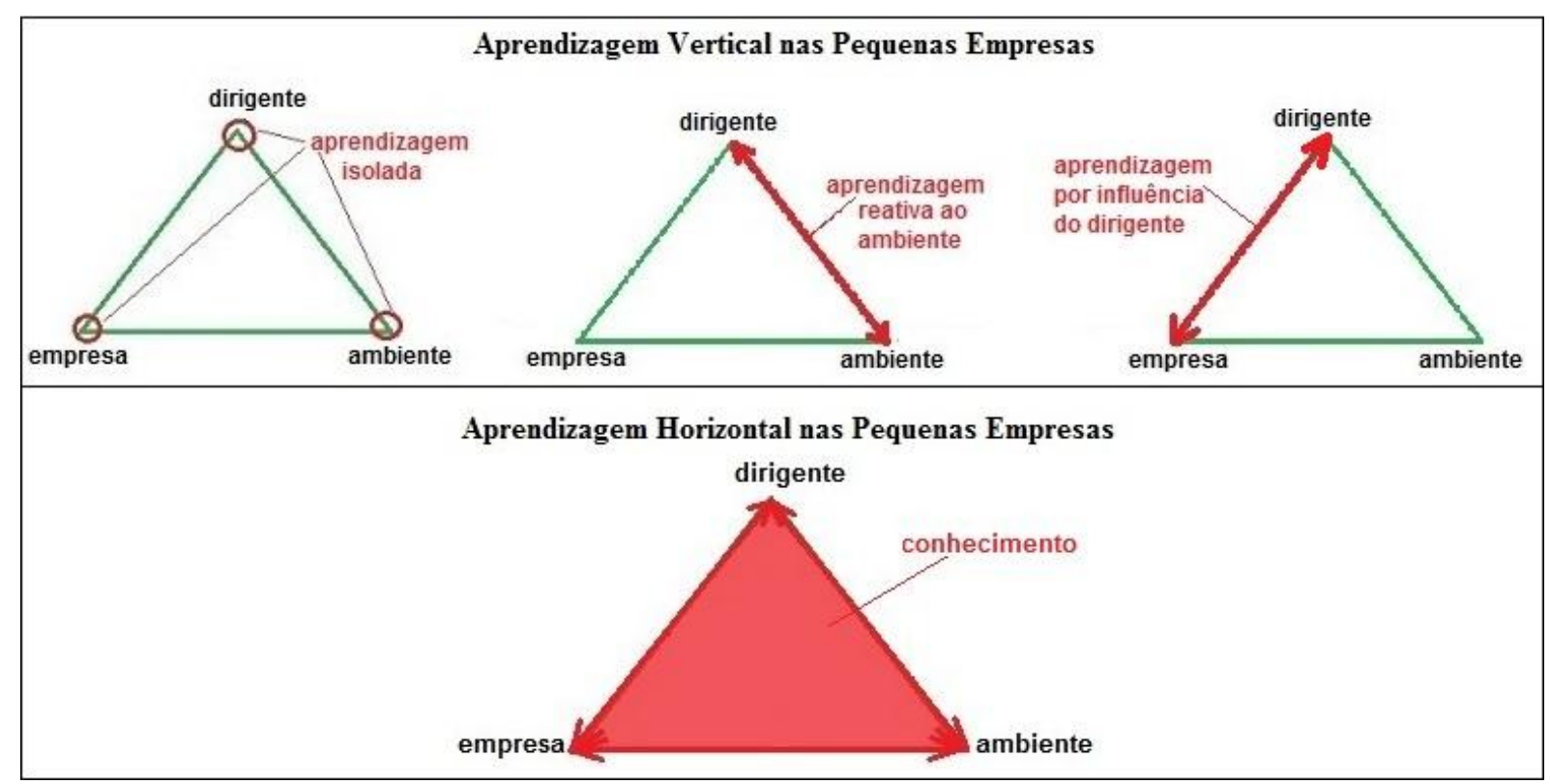

Figura 5.1 - Aprendizagem vertical e aprendizagem horizontal no contexto da pequena empresa

Assim, a aprendizagem vertical na pequena empresa pode ser ilustrada por uma reta, correspondente a um dos vértices do "triângulo das especificidades", ao passo que a 
aprendizagem horizontal corresponde ao plano que integra as interações que ocorrem entre as três dimensões, dirigente, empresa e ambiente.

A seguir, é preciso verificar se o mapa conceitual formado na Figura 5.1 encontra respaldo na realidade das pequenas empresas. Para isso será utilizado um estudo de caso instrumental, que analisará uma pequena empresa de base tecnológica da cidade de São Carlos. O Capítulo 6 descreverá os métodos empregados para o trabalho de campo e o Capítulo 7 trará o relatório de caso único, utilizando os mesmos elementos formadores dos construtos pesquisados e seguindo a metodologia de caso único proposta por Stake (1995).

\subsection{Caracterização e Desenho da Pesquisa}

Segundo o raciocínio desenvolvido no capítulo de Introdução, o paradigma de pesquisa adotado foi o Interpretativista (BURRELL; MORGAN, 1979). Isso implica que a pesquisa procurou construir significados, criando e validando novos construtos. Nesse caso os métodos qualitativos são os que melhor se encaixam aos objetivos da pesquisa, já que a proposta de campo é justamente verificar o mapa conceitual em um ambiente natural, procurando integrar conceitos e experiência a partir de um referencial teórico (TURATO, 2005; MARTIN et al., 2006). Essas são características da pesquisa qualitativa: fundamentalmente interpretativa, emergente, que ocorre em um cenário natural e emprega métodos múltiplos, interativos e humanísticos (CRESWELL, 2007).

Dessa forma, a pesquisa foi inicialmente descrita como qualitativa e exploratória, pois pretendia ser orientada para o processo e utilizada para compreender, interpretar e descrever certo fenômeno. De acordo, os métodos de coleta definidos foram entrevistas semiestruturadas e a observação participante. As entrevistas foram gravadas e transcritas. Um diário de campo detalhado foi criado durante a visita e analisado posteriormente.

Durante a fase de análise dos dados, entretanto, a adequação de técnicas de análise qualitativas foi questionada, já que, para que a verificação da adequação dos construtos fosse bem conduzida, os participantes não poderiam conhecê-lo a priori e, portanto, não poderiam atribuir significado. Do ponto de vista ético também houve um problema: a necessidade de sigilo das informações coletadas não permitiu a explicitação do processo de interpretação dos dados, pois, não havendo o compartilhamento de significados com os autores do processo, não havia como fazer uma análise indutiva dos significados atribuídos.

Dois autores ofereceram soluções para estes problemas: em primeiro lugar, Berto e Nakano (1998) propuseram um método de pesquisa denominado teórico-conceitual, definido 
como o "produto de reflexões a partir de um fenômeno observado ou relatado pela literatura (revisão bibliográfica); compilação de ideias e opiniões de diferentes autores ou ainda simulação e modelagem teórica" (BERTO; NAKANO, 1998, p. 5). Nesse caso também são incluídas as observações de campo não estruturadas.

Em segundo lugar, Stake (1995) propôs um modelo de análise de estudo de caso único com o formato de "relatório de caso", composto basicamente de uma narrativa que procura relatar como as questões de pesquisa foram respondidas pela experiência em campo.

Assim, o desenho da pesquisa ficou assim definido:

- Quanto ao seu propósito, a pesquisa é exploratória, pois procura aprofundar conhecimentos sobre uma área pouco conhecida ou descrever fenômenos ainda pouco explorados;

- Quanto à abordagem do problema, é uma pesquisa qualitativa, pois busca uma profunda compreensão de um fenômeno a partir de um ponto de vista interno à organização;

- Quanto aos procedimentos técnicos, é um estudo de caso individual instrumental, pois utiliza um caso particular para refinar a teoria.

O Quadro 5.3 resume o protocolo de pesquisa.

Para garantir a validade da pesquisa (CRESWELL, 2007) foi utilizada a triangulação de resultados (todos os membros da empresa foram entrevistados), o tempo em campo foi o mais prolongado possível, com a presença em período integral da pesquisadora durante uma semana inteira e a gravação e participação em duas reuniões de resultado. 
Quadro 5.3 - Protocolo de pesquisa

\begin{tabular}{|c|c|c|c|c|c|}
\hline \multicolumn{6}{|c|}{$\begin{array}{l}\text { Objetivo Geral: verificar a adequação do mapa conceitual de aprendizagem organizacional na } \\
\text { pequena empresa }\end{array}$} \\
\hline $\begin{array}{l}\text { Objetivo } \\
\text { específico }\end{array}$ & $\begin{array}{l}\text { Questões de Pesquisa } \\
\text { Específicas }\end{array}$ & $\begin{array}{l}\text { Tipo de } \\
\text { Pesquisa }\end{array}$ & $\begin{array}{l}\text { Coleta } \\
\text { de } \\
\text { Dados }\end{array}$ & $\begin{array}{l}\text { Técnica } \\
\text { de Análise } \\
\text { de Dados }\end{array}$ & Respondentes \\
\hline $\begin{array}{l}\text { Verificação da } \\
\text { coerência } \\
\text { interna dos } \\
\text { construtos de } \\
\text { aprendizagem } \\
\text { horizontal e } \\
\text { aprendizagem } \\
\text { vertical }\end{array}$ & $\begin{array}{l}\text { 01: As interações entre dirigente } \\
\text { e mercado geram } \\
\text { aprendizagem? A aprendizagem } \\
\text { é absorvida pelo código da } \\
\text { empresa? } \\
\text { u 2: As interações entre } \\
\text { dirigente e organização geram } \\
\text { aprendizagem? A aprendizagem } \\
\text { é absorvida pelo código da } \\
\text { empresa? } \\
\text { u 3: As interações entre } \\
\text { organização e mercado geram } \\
\text { aprendizagem? A aprendizagem } \\
\text { é absorvida pelo código da } \\
\text { empresa? } \\
\text { v 4: Há interações conscientes } \\
\text { com o código da empresa? } \\
\text { v 5: Há interrelação entre as } \\
\text { características de hierarquia, } \\
\text { especialização, centralização, } \\
\text { estratégia, cultura, resultado e } \\
\text { efeito da aprendizagem vertical? } \\
\text { v 6: Há interrelação entre as } \\
\text { características de hierarquia, } \\
\text { especialização, centralização, } \\
\text { estratégia, cultura, resultado e } \\
\text { efeito da aprendizagem } \\
\text { horizontal? }\end{array}$ & 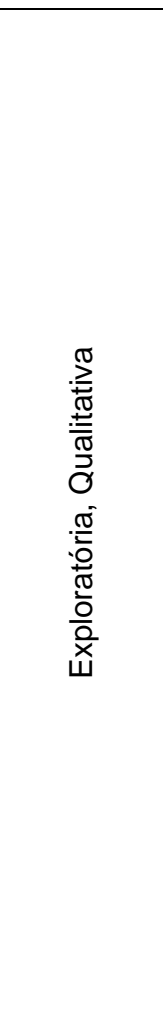 & 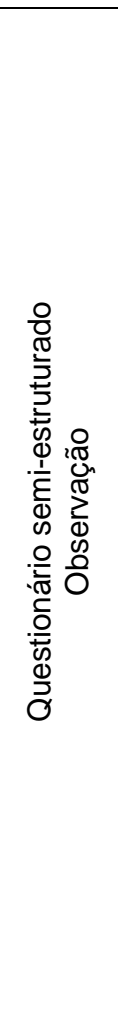 & 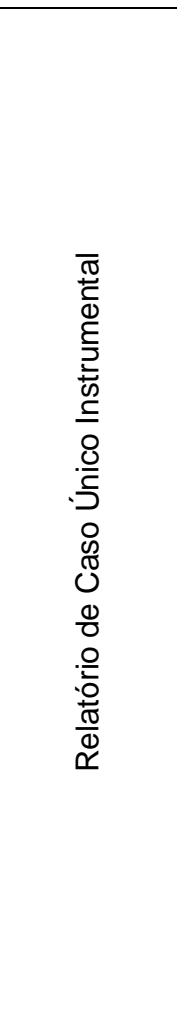 & $\begin{array}{l}\text { Todos os } \\
\text { membros da } \\
\text { empresa } \\
\text { visitada } \\
\text { (7 pessoas) }\end{array}$ \\
\hline
\end{tabular}

\subsubsection{Delimitação do Estudo de Caso}

A aplicação da técnica do caso único instrumental implica em especial cuidado na definição do caso, que deve funcionar como um "sistema delimitado" ("bounded system"), ou seja, um conjunto de partes em funcionamento com uma determinada intencionalidade, constituindo um sistema integrado de natureza própria e dentro do qual há padrões de comportamento, mantendo certa coerência e sequencialidade. Também é importante definir o seu contexto, e os limites que determinam o que faz parte do caso, o que está na fronteira do caso e o que está fora do caso (STAKE, 1995; 2008).

Assim, foi feita a escolha deliberada da empresa a ser visitada, atendendo ao conjunto de requisitos que potencializa as oportunidades de aprendizagem: a empresa já passou por um ciclo completo de lançamento de produto no mercado (implicando na presença de algum tipo de processo de aprendizagem), a empresa é pequena o suficiente para que todos os seus membros participem da pesquisa (para que o estudo tenha profundidade e abrangência), mas 
grande o suficiente para apresentar uma estrutura administrativa mínima (o que permite a verificação do mapa conceitual em todos os seus elementos), a empresa é de base tecnológica e está em funcionamento em um mercado competitivo (o que implica em constante processo de aprendizagem) e, finalmente, os membros da empresa estavam dispostos a colaborar com o estudo.

Os limites do caso foram assim definidos: sistema composto pelas sete pessoas que trabalham na sede da empresa (um sócio-dirigente, um sócio-pesquisador, um estagiário de engenharia, um estagiário técnico em mecatrônica, dois técnicos em mecatrônica e um vendedor) e seus recursos. A empresa está em funcionamento há dois anos, inserida na indústria de Equipamentos Médico-hospitalares e Odontológicos, oferecendo produtos para clínicas e laboratórios e projetos customizados e serviços de suporte a aplicações destinadas à pesquisa científica. Fazem parte do caso as sete pessoas que trabalham na empresa. No limite do caso estão as três pessoas que trabalham na empresa que divide a sala alugada dentro da incubadora e professores universitários, que colaboraram com o desenvolvimento de alguns produtos, mas não participam do dia-a-dia da empresa. Estão fora do caso fornecedores, clientes, as demais empresas da incubadora da qual a empresa faz parte e quaisquer outros visitantes.

\subsubsection{Preparação para a Entrevista}

Todos os participantes foram avisados sobre o processo, receberam as cartas de anuência e tiveram a oportunidade de tirar dúvidas em relação à pesquisa, ao processo e a seus objetivos.

A lista de questões do Quadro 5.4 foi levada em todas as entrevistas e serviu como guia para a entrevista, para garantir que os elementos formadores dos construtos sendo pesquisados, a aprendizagem vertical e a aprendizagem horizontal, fossem contemplados. A ordem e a formulação das perguntas, entretanto, variou em função das respostas recebidas e de acordo com o fluxo de informações. 
Quadro 5.4 - Roteiro para as Entrevistas Semi-Estuturadas

\begin{tabular}{|c|c|}
\hline $\begin{array}{l}\text { Elemento do } \\
\text { Construto }\end{array}$ & Questões \\
\hline \multirow[b]{2}{*}{ Formalização } & 1) A empresa possui procedimentos formalizados? Quais? \\
\hline & $\begin{array}{l}\text { 2) Após o término de um projeto há algum tipo de discussão ou arquivamento } \\
\text { para referência futura? }\end{array}$ \\
\hline \multirow{3}{*}{ Especialização } & 3) Quais as suas responsabilidades na empresa? \\
\hline & 4) Em qual(is) projeto(s) você está mais envolvido no momento? \\
\hline & 5) Como você contribui com ideias para os projetos? \\
\hline \multirow{2}{*}{$\begin{array}{l}\text { Hierarquia/ } \\
\text { Tecnologia }\end{array}$} & 6) A empresa possui organograma? \\
\hline & 7) Como são distribuídas as tarefas e atividades aos membros da empresa? \\
\hline \multirow{2}{*}{ Centralização } & 8) Há reuniões de equipe? \\
\hline & 9) Como é o processo de tomada de decisão da empresa? \\
\hline \multirow{2}{*}{ Profissionalismo } & 10) Você ou a empresa investem na sua formação profissional? Como? \\
\hline & 11) Como a equipe técnica foi formada? \\
\hline \multirow{3}{*}{ Ambiente } & 12) Qual é o mercado da empresa e quais os principais concorrentes? \\
\hline & 13) A empresa possui parceiros ou fornecedores prioritários? Terceirizados? \\
\hline & 14) Como é a relação de vocês com os clientes? \\
\hline \multirow{2}{*}{ Metas } & 15) Quais serão os próximos projetos? \\
\hline & 16) Quais são as principais metas da empresa? A curto prazo? A longo prazo? \\
\hline \multirow{2}{*}{ Cultura } & 17) Vocês experimentam novas ideias? De que forma? Com que frequência? \\
\hline & 18) Quando há um problema técnico, como ele é resolvido? \\
\hline
\end{tabular}




\section{Relatório de Estudo de Caso Único Instrumental}

Seguindo os moldes do relatório de caso único instrumental proposto por Stake (1995), este capítulo descreve os resultados do trabalho de campo e os relaciona aos construtos investigados, a aprendizagem vertical e a aprendizagem horizontal na pequena empresa.

\subsection{Descrição da Empresa}

A empresa localiza-se na cidade de São Carlos, SP, dentro da incubadora de empresas do ParqTec. Assim sendo, ela ocupa três ambientes distintos para a execução de suas atividades: a sala que aluga, a oficina mecânica e a sala de reuniões.

Há basicamente três divisões funcionais, que acabam por ter sua contraparte física: a parte de mecânica, que fica situada na oficina, a parte de eletrônica, que fica situada atrás do escritório, e a parte de administração e vendas, que fica situada na entrada do escritório. Há uma "quarta parte" virtual, de pesquisa, composta principalmente pelo sócio-pesquisador. A parte de eletrônica deverá, num futuro próximo, englobar também uma parte de óptica.

A sala alugada dentro da incubadora é dividida em dois ambientes, separados por uma divisória: o primeiro, na entrada, contém três mesas de trabalho, 2 mesas de apoio, 1 mesa de centro e um sofá para recepção. O segundo, localizado atrás da divisória, contém duas bancadas paralelas encostadas à parede: uma serve como mesa para os computadores e a outra como bancada de laboratório, para a parte de eletrônica. Na parede dos fundos há prateleiras para guardar equipamentos e materiais maiores. Ao lado da bancada adjacente à divisória há um armário para guardar materiais e equipamentos pequenos. A sala é compartilhada com outra empresa encubada. Uma das mesas de trabalho da entrada pertence ao dirigente da outra empresa e as bancadas, computadores e equipamentos da parte de eletrônica são compartilhados por funcionários das duas empresas.

As duas mesas que ficam na entrada da sala abrigam o sócio-dirigente e o vendedor. Além do sofá e da mesa de centro, que compõem uma sala de reuniões na entrada, há também uma mesa para café e bolachas. As bancadas geralmente são compartilhadas pelo estagiário de engenharia e pelo técnico em eletrônica. Essa seção da sala representa fisicamente o que seria a "Divisão de Eletrônica" da empresa. Há dois quadros brancos na parede. 
A oficina mecânica fica nos fundos da incubadora, distante da sala. Esta oficina é alugada, mas com a condição de ser compartilhada com outras empresas incubadas em caso de necessidade. Na oficina há um torno, uma fresa, uma prensa térmica, um tanque, um armário, duas bancadas que são utilizadas para apoio e uma mesa com computador. Há um quadro branco em uma das paredes e um quadro de ferramentas na outra.

Por fim, a sala de reuniões é compartilhada por todas as empresas incubadas e seu uso deve ser agendado com antecedência. A empresa utiliza o horário de segunda-feira, das 8:30 às 10:00 h, todas as semanas, para fazer sua reunião semanal. A sala de reuniões possui uma mesa grande, 6 cadeiras de reunião e um aparador.

A sala de reuniões e a sala da empresa possuem ar condicionado. A oficina não. Na maior parte do tempo, há uma constante circulação de pessoas entre a sala da empresa e a oficina (para pegar materiais, para tirar dúvidas, para conversar).

O horário de trabalho da empresa é das 8:00 às 17:00, de segunda à sexta-feira.

Além das instalações da empresa, o sócio-pesquisador trabalha em uma universidade na cidade de Santo André, SP. Sua entrevista foi conduzida em sua sala na universidade, mas o restante da parte de campo foi realizada inteiramente dentro das instalações aqui descritas.

\subsection{Entrevistas e Observação}

As entrevistas foram realizadas na semana de 20 a 24 de agosto de 2012 . Sua duração média foi de meia hora, à exceção da entrevista com o sócio-dirigente, que durou aproximadamente 75 minutos. A entrevista com o sócio-pesquisador foi realizada em sua sala na universidade em Santo André, no dia 28 de agosto, e teve duração de aproximadamente 65 minutos. Além das entrevistas também foram transcritas duas reuniões semanais, uma no dia 20 de agosto, com duração de 68 minutos, e a outra no dia 27 de agosto, com duração de 57 minutos.

O objetivo das entrevistas foi averiguar se os atores do processo tinham consciência das interações do seu cotidiano e do resultado dessas interações do ponto de vista da aprendizagem individual e organizacional. Além disso, as entrevistas procuraram obter confirmação verbal de como funcionam os elementos estruturais e contextuais interrelacionados que compõem os construtos de aprendizagem horizontal e vertical: aprendizagem, hierarquia, especialização, centralização, integração, estratégia, cultura, resultado e efeito. 
A observação foi efetuada na semana de 10 a 14 de setembro, dentro de todo o período de funcionamento da empresa. O diário de campo consiste em anotações feitas durante a observação, contendo o horário, o local na empresa e os atores da ação observada. O foco da observação foram as interações entre os atores das ações observadas e suas consequências do ponto de vista da aprendizagem. O mapa conceitual construtos de aprendizagem horizontal e vertical foi contrastado com as situações testemunhadas.

\subsection{Os componentes da Aprendizagem Horizontal e da Aprendizagem Vertical}

1) Formalização - a empresa possui um sistema de documentação de projetos e se preocupa em mantê-lo atualizado e disponível para todos os funcionários. Todos os funcionários relataram, durante a entrevista, a atualização da documentação como parte de sua rotina. "a gente tenta fazer uma documentação (...) que deve ser um roteiro da montagem. Caso eu e o (...) saiamos da empresa, chega outra pessoa, consiga abrir o documento que a gente criou aqui e fazer a mesma coisa que a gente fez". Além disso, a busca por informações é encorajada: todos possuem acesso irrestrito à Internet e aos documentos e protótipos da empresa. Por outro lado, verifica-se o alto grau de informalidade já previsto na literatura. Durante a observação a visita de um fornecedor gerou uma dúvida relativa a um produto mais antigo da empresa. O técnico que o estava atendendo pegou o protótipo, desmontou e descobriu a resposta junto com o vendedor. Quanto interrogado sobre a documentação do projeto, respondeu "nem lembrei disso. A cicladora 'tava aí do lado, mesmo".

2) Especialização - há uma especialização de tarefas definida pelas três divisões funcionais: mecânica, eletrônica e ótica. Dentro dessas grandes áreas, entretanto, todos fazem um pouco de tudo. As entrevistas confirmaram que há pouca especialização de tarefas na prática: "Nossas aplicações nunca se resumem só a uma parte de cada setor da empresa (...) sempre acaba misturando pelo menos eletrônica e mecânica."

Há uma preocupação óbvia em demonstrar conhecimento e competência. Todos sabem o "currículo" de cada um e o nível de conhecimento que a pessoa demonstra possuir define sua "credibilidade". Durante a observação houve inúmeros casos em que uma pessoa sem a credibilidade necessária contribuía, mas sua contribuição não 
era considerada. Por outro lado, se a pessoa tivesse credibilidade suficiente, sua contribuição era sempre considerada, mesmo que descartada imediatamente depois. Soluções para problemas novos e/ou em início de projeto tendem a ser discutidas por toda a empresa. Já em final de projeto, na fase de definição de especificações definitivas ou na solução de problemas específicos de alguma área, os problemas tendem a ser resolvidos de maneira mais hierarquizada (estagiário $\rightarrow$ chefe $\rightarrow$ sóciodirigente) e pontual.

3) Hierarquia - Como é característico da pequena empresa, o sócio-dirigente controla e centraliza as decisões, apesar de conferir autonomia aos funcionários. As reuniões semanais, além de informar a todos o que ocorre na empresa, também tem a função de manter o sócio-dirigente "no comando", pois é nessa reunião que todas as aprovações são efetuadas e as decisões mais importantes ratificadas. Além disso, tanto a área de eletrônica quanto a área de mecânica possuem um "chefe" definido, que tem o poder de tomar decisões na ausência do sócio-dirigente e é responsável pelo andamento da sua "divisão".

Na prática, entretanto, todos os entrevistados concordam que a empresa lhes confere bastante autonomia para tomada de decisões e a pró-atividade é encorajada. Além disso, todos possuem formação técnica adequada para suas atividades e fazem questão de salientar este ponto. Na realidade, apesar de todos descreverem a estrutura da empresa com três níveis hierárquicos, na prática a autoridade é definida pelo grau de conhecimento do assunto: "É bem horizontal, a meu ver. A gente tenta deixar tudo horizontal pra fluir da melhor maneira possível (...) todo mundo conversa, todo mundo brinca e todo mundo discute tudo junto". "Acho que eles me respeitam por que... tipo... e u faço USP". "Só o (...) tá fazendo doutorado". "Tem essa hierarquia do engenheiro estar acima do técnico..."

Assim, a empresa consegue funcionar das duas formas: hierarquizada (com três níveis de gerência para 6 pessoas) na forma e bem mais orgânica no início dos projetos. No primeiro dia de observação todos ainda estavam procurando a melhor solução para o resfriamento de uma cuba até 5 C. Havia uma serpentina de chope emprestada de um fornecedor que havia acabado de ser abandonada e um protótipo recém encomendado pelos funcionários da mecânica que estava entrando em fase de ensaio. Logo após a reunião semanal, nas primeiras duas horas da semana, todos os funcionários (até o de vendas) foram mexer na peça recém-chegada. No segundo dia de observação vizinhos de incubadora e até a pesquisadora se envolveram com a 
solução de problemas levantados durante os ensaios. O sócio-dirigente só foi ver a peça no terceiro dia, quando ela já estava diferente do original.

Por outro lado, um outro equipamento estava em fase final de fechamento de projeto e era necessário escolher o tipo de motor que seria definido nas especificações definitivas. O estagiário fez três ensaios, mostrou ao chefe da eletrônica, que fez suas observações e chamou o sócio-dirigente para que este pudesse dar a palavra final.

4) Centralização - O sócio-pesquisador não participa do dia-a-dia da empresa e não é conhecido pela maioria dos funcionários. Já o sócio-dirigente é bastante presente, e participa ativamente do processo de execução dos projetos, assumindo, do ponto de vista técnico, basicamente dois papeis: o de mentor e o de "juiz", dando a palavra final sobre as decisões a serem tomadas na escolha da solução a ser implantada em cada projeto. Sua postura encoraja a troca de ideias e a experimentação ("vamos testar" é uma frase que repete bastante). Tende a ouvir com atenção todas as ideias recebidas e pensar antes de responder. Mesmo as respostas negativas tendem a ser suavizadas e colocadas na forma de prioridades ("por que você não faz (...) primeiro?") e não negativas absolutas. "Ai eu falei com o [dirigente], falei vou mudar, cara, por que assim não dá, né?" "O [dirigente] é uma pessoa de mente muito aberta".

Já em relação às interações relativas às questões não técnicas (compras e vendas, primariamente) o sócio-dirigente é bem mais incisivo, procura controlar mais o processo de aquisição de informações e acompanha os resultados mais de perto. "Daí a gente vai vendo o melhor caminho (...) A palavra final é do (...), mas cada um expõe suas ideias e ele fala o que ele acha melhor".

5) Profissionalismo - como já discutido no item 1), a formação técnica e a aprendizagem são muito valorizadas. "Meu objetivo é aprender". "'O (...) já recomendou para mim ler, ele já me deu um toque, ó, lê bastante..." "Tá todo mundo aprendendo." As interações pessoais vão se fortalecendo à medida em que as pessoas passam por experiências de solução conjunta de problemas. Dois funcionários atenderam um cliente que ligou com uma dúvida que ninguém sabia responder e, juntos, encontraram a resposta. Depois disso, o número de interações (tanto sociais quanto técnicas) entre eles cresceu bastante. "Um ajuda o outro, dá uma força aqui, dá uma força ali..." "Falei ó, (...), eu não entendo muito, ele me ajudou, sabe?" "Ele fornece bastante conhecimento para gente." 
A própria pesquisadora provocou uma experiência semelhante: no primeiro dia de observação ficou claro que a observação alterava o comportamento das pessoas (funcionários trocavam de atividade quando a pesquisadora entrava no ambiente). Após o envolvimento da pesquisadora na solução de um problema, entretanto, as pessoas envolvidas passaram a considerá-la "do grupo" e a mudança de comportamento deixou de ocorrer. As pessoas que não participaram da solução, apesar de demonstrar mais desembaraço ao longo da semana, continuaram mantendo uma certa distância.

Também há um nível muito alto de pró-atividade e experimentação. "A gente corre atrás das coisas pra ver como é que faz". "Eu olhei: não, tá errado, não tá legal, tá muito confuso, então eu vou mudar. Aí escolhi as cores novas e mudei o projeto". Apesar do número de funcionários ser pequeno, há diversidade na forma de trabalhar e de resolver problemas e essa diversidade é respeitada. As pessoas são encorajadas a procurar soluções à sua maneira e ao seu tempo, e a se autodesenvolverem. "O [dirigente] comentou para mim (...) ver uma revista para ele assinar". "Daí esse software aí, eu nunca trabalhei com ele, tou vendo agora, aqui na empresa, primeira vez. Daí o (...) tá me ajudando e tá meio difícil, né? (...) Ele aprendeu sozinho também, ninguém ensinou ele".

Dois funcionários pediram tempo fora do trabalho para participar da Olimpíada do Conhecimento, e foram dispensados, embora por menos tempo do que o requisitado.

6) Taxas de pessoal - reconhecendo que o controle da rotatividade de pessoal é tarefa bem difícil para uma pequena empresa, os sócios-dirigentes resolveram adotar medidas para minimizar seu impacto. Partindo do princípio que a empresa estaria sujeita a trocas constantes de pessoal, a estrutura já foi desenhada para que sempre houvesse uma pessoa em treinamento e uma pessoa mais antiga, responsável pela "memória" da empresa e transmissão do código. "Essa é que é a ideia. Então. É deixar tudo de forma organizada que a pessoa já olhe e já entenda o que tá acontecendo". "Por que a intenção é, assim como a documentação, é ser tudo facilmente montável (...) a pessoa olha e já pode começar a fazer a montagem".

7) Tamanho (integração) - a característica mais marcante da empresa é a integração entre as pessoas que nela trabalham. Há uma troca constante de informações. As pessoas circulam bastante não só fisicamente pela empresa, mas também de um "problema" para outro. Todos são encorajados a participar da busca de soluções para o projeto sendo executado e todos sabem quais são as questões sendo debatidas no 
momento. As fases de cada projeto sendo desenvolvido também são compartilhadas, não só nas interações do dia-a-dia, mas também formalmente, nas reuniões semanais. "Os projetos são atrelados". "Se a gente ficar só na cicladora o resto dos projetos não andam, né?". Durante a observação ocorreu pelo menos um caso de uma pessoa dar explicações sobre o trabalho executado por outra pessoa. Os quadros brancos são utilizados continuamente, por todos da empresa, tanto na oficina quanto no escritório. "A gente vem, senta juntos, vê os resultados".

8) Tecnologia - Como todos são envolvidos nos estágios iniciais de todos os projetos, todos se envolvem com sua execução. Há uma curiosidade natural. Apesar de alguns estágios serem executados pontualmente, de acordo com as necessidades de cada etapa do projeto, cada projeto novo agrega aprendizagem para toda a empresa, já que introduz tecnologias na área de mecânica, eletrônica e óptica

9) Ambiente - Os entrevistados atribuem pouca importância à dimensão ambiente, considerando apenas "a Internet" como fonte de informações externas. A maior parte dos entrevistados não soube mencionar fontes de informação, aprendizagem ou solução de problemas fora da própria empresa sem algum tipo de sugestão. $\mathrm{Na}$ prática, entretanto, foram detectadas várias trocas distintas: os funcionários técnicos trocam informações e experiências com fornecedores e colegas da incubadora. Já os sócios e o vendedor mantém contato com professores universitários, principalmente, que são seus principais clientes, e órgãos de fomento. Não há "cruzamento", entretanto: os sócios não conversam com fornecedores e os funcionários não entram em contato com os clientes (à exceção de "emergências", como o atendimento ao cliente relatado no item 5) e não possuem conhecimento do tipo de informação trocada com órgãos de fomento.

As interações entre os sócios e os clientes são as mais próximas, já que a empresa oferece projetos customizados e mantém um contato crescente com os pesquisadores que encomendam soluções para atender seus protocolos de pesquisa. Já as demais interações com o ambiente são bem mais fracas e esparsas. Há dois fornecedores que podem vir a tornar-se parceiros e que contribuem com soluções pontuais. "Ele é um profissional, tem bastante experiência com usinagem. Ele fornece muito conhecimento pra gente".

10) Metas e estratégias - a entrevista com o sócio dirigente deixou claro que a maior parte das características estudadas foi deliberadamente estruturada durante a concepção da empresa. Ambos os sócios possuem uma visão muito clara da 
estrutura, dos objetivos e dos recursos da empresa, que está na fase de prospecção de mercado e tentando lançar linhas de produto, além de projetos customizados.

Em relação aos funcionários, destacou-se a semelhança das respostas em relação a metas futuras: todos sabem que a meta dos sócios da empresa é o crescimento e a expansão rápidos ("crescer junto com a empresa" foi repetido várias vezes), embora não saibam especificar como essa meta se traduz em números. "O foco é a gente entrar no mercado". Há uma exceção, de um funcionário que não parece estar muito interessado nas metas da empresa.

Além disso, todos sabem, em detalhes, relatar os últimos projetos efetuados e quais os projetos que estão sendo desenvolvidos no momento. Nem sempre se conhece, entretanto, qual o próximo projeto na pauta. "Eu não sei como vai ser certinho, por que tá tudo muito por cima ainda". "A gente não conversou, não sentou pra conversar disso, (...) mas a agente sempre acaba discutindo sobre os projetos, né? Por que no final sou eи que puxo, que tenho que meio que ter as ideias pra implementar (...) mudar as coisas..." "Ah, a empresa planeja crescer, né?"

11) Cultura - ambos os dirigentes deixaram claro que procuram definir uma cultura de inovação e aprendizagem na empresa ("Nacionalizar é desenvolver os nossos próprios parâmetros para as coisas"). Todos gostam de explicar e transferir conhecimentos, uns ensinam aos outros o que sabem. Foi possível também detectar várias ocorrências de aprendizagem de laço duplo. "Foi o que eu conversei com o [dirigente]: ah, eu vacilei e tudo o mais. E ele ah, mas tudo bem, a gente descobriu um problema (...) Melhor descascar aqui com a gente do que lá no laboratório do dentista. Foi um erro que foi bom, no fim das contas"... "Errar experimentando é parte do trabalho, errar por falta de atenção, não". "Se der errado? a gente se reúne, vê... como pode ser mudado pra dar certo... e tenta fazer certo".

Há uma forte tendência à experimentação e liberdade para tentar várias coisas. Por outro lado, todos os funcionários são extremamente conscientes da necessidade de cortar custos, que são o primeiro ou segundo critério considerado em todas as decisões tomadas. 


\subsection{Discussão}

A empresa parece funcionar de maneira verdadeiramente ambidestra, explorando novas possibilidades no início de cada projeto e aprofundando conhecimentos na etapa final (TUSHMAN; O’REILLY III, 1996). Assim, foi possível detectar dois conjuntos variados de elementos que compõem a aprendizagem vertical e a aprendizagem horizontal. Por um lado, a empresa possui um sistema formalizado de memória organizacional e trabalha de maneira multidisciplinar, pouco hierarquizada, pouco centralizada, de maneira bastante integrada, com alta competência técnica e aprendizado constantes, gerenciando suas taxas de rotatividade, conscientes das grandes metas comuns e trocando informações constantemente com seu ambiente.

Por outro lado, nem sempre a documentação é utilizada, há uma clara separação de departamentos e hierarquia (mesmo num grupo tão pequeno), as informações provenientes do ambiente nem sempre são difundidas e há muitas informações sobre metas e projetos desconhecidas dos funcionários. Isso implica que a empresa consegue aprender de maneira horizontal no início dos projetos e de maneira vertical ao final deles. O Quadro 6.1 ajuda a compreender melhor como os elementos da aprendizagem vertical e da aprendizagem horizontal se aproximam da realidade da empresa.

Quadro 6.1: Aprendizagem vertical e aprendizagem horizontal na empresa estudada

\begin{tabular}{|l|l|l|}
\hline Elemento & Aprendizagem vertical & Aprendizagem horizontal \\
\hline Ocorrência & Finalização de projetos & Início dos projetos \\
\hline $\begin{array}{l}\text { Tipo de } \\
\text { aprendizagem }\end{array}$ & $\begin{array}{l}\text { Correção de erros e melhoria de } \\
\text { produtos (adaptativa) }\end{array}$ & $\begin{array}{l}\text { Experimentação, seleção de ideias } \\
\text { (generativa) }\end{array}$ \\
\hline Hierarquia & $\begin{array}{l}\text { Estagiário } \rightarrow \text { "Chefe da divisão" } \rightarrow \\
\text { Sócio-dirigente }\end{array}$ & Não há, todos trabalham em conjunto \\
\hline Especialização & $\begin{array}{l}\text { Maior especialização, com pessoas } \\
\text { desenvolvendo atividades de } \\
\text { maneira isolada. }\end{array}$ & $\begin{array}{l}\text { Menor especialização busca de soluçães } \\
\text { em grupo ('desde que a pessoa seja } \\
\text { considerada "habilitada" a participar do } \\
\text { grupo) }\end{array}$ \\
\hline Centralização & $\begin{array}{l}\text { Alta, a decisão final é do sócio- } \\
\text { dirigente }\end{array}$ & $\begin{array}{l}\text { Baixa, alguém assume a } \\
\text { responsabilidade pela escolha realizada } \\
\text { no momento e continua o } \\
\text { desenvolvimento }\end{array}$ \\
\hline $\begin{array}{l}\text { Tamanho } \\
\text { (integração) }\end{array}$ & $\begin{array}{l}\text { Baixa, divisão de tarefas entre as } \\
\text { áreas de mecânica, eletrônica e ótica }\end{array}$ & $\begin{array}{l}\text { Alta, com livre fluxo de informações e } \\
\text { trocas de conhecimento entre as áreas }\end{array}$ \\
\hline Estratégia & $\begin{array}{l}\text { De curto prazo voltada à finalização } \\
\text { do projeto }\end{array}$ & $\begin{array}{l}\text { De prazo indefinido, voltada à finalização } \\
\text { de um protótipo }\end{array}$ \\
\hline
\end{tabular}


Quadro 6.1: Aprendizagem vertical e aprendizagem horizontal na empresa estudada (continuação)

\begin{tabular}{|l|l|l|}
\hline Cultura & $\begin{array}{l}\text { Interações de laço único } \\
\text { (remanufatura de peças, revisão de } \\
\text { problemas isolados) }\end{array}$ & $\begin{array}{l}\text { Interações de laço duplo (revisão de } \\
\text { projetos, correções de rumo para o } \\
\text { protótipo) }\end{array}$ \\
\hline Resultado & $\begin{array}{l}\text { Adaptação: entregar o produto final } \\
\text { para o cliente }\end{array}$ & $\begin{array}{l}\text { Adaptabilidade: criar um novo produto } \\
\text { que pode vir a entrar numa linha de } \\
\text { produção }\end{array}$ \\
\hline Efeito & Localizado & Disseminado por toda a empresa \\
\hline
\end{tabular}

Assim, os construtos propostos para a formação do mapa conceitual - aprendizagem vertical e aprendizagem horizontal - encontraram verificação inicial na prática, durante a etapa de campo.

A seguir é necessário verificar o mapa conceitual de aprendizagem nas pequenas empresas à luz dos dados colhidos em campo. Para isso, será construído um mapa de aprendizagem da empresa estudada.

\subsubsection{O mapa de aprendizagem da empresa estudada}

Para formar o mapa de aprendizagem da empresa é preciso verificar primeiro quais são as interações que ocorrem na empresa e quais são os atores dessas interações. Assim, a dimensão "dirigente" é composta por dois atores, o sócio-dirigente e o sócio-pesquisador. A dimensão "empresa" é composta por cinco funcionários, divididos entre as divisões de mecânica, eletrônica e vendas. Finalmente, a dimensão "ambiente", no caso estudado, se compõe de clientes, fornecedores e agências de fomento, que no momento viabilizam a empresa financeiramente. A Figura 6.1 ilustra as três dimensões que são a base do mapa de aprendizagem da pequena empresa: 


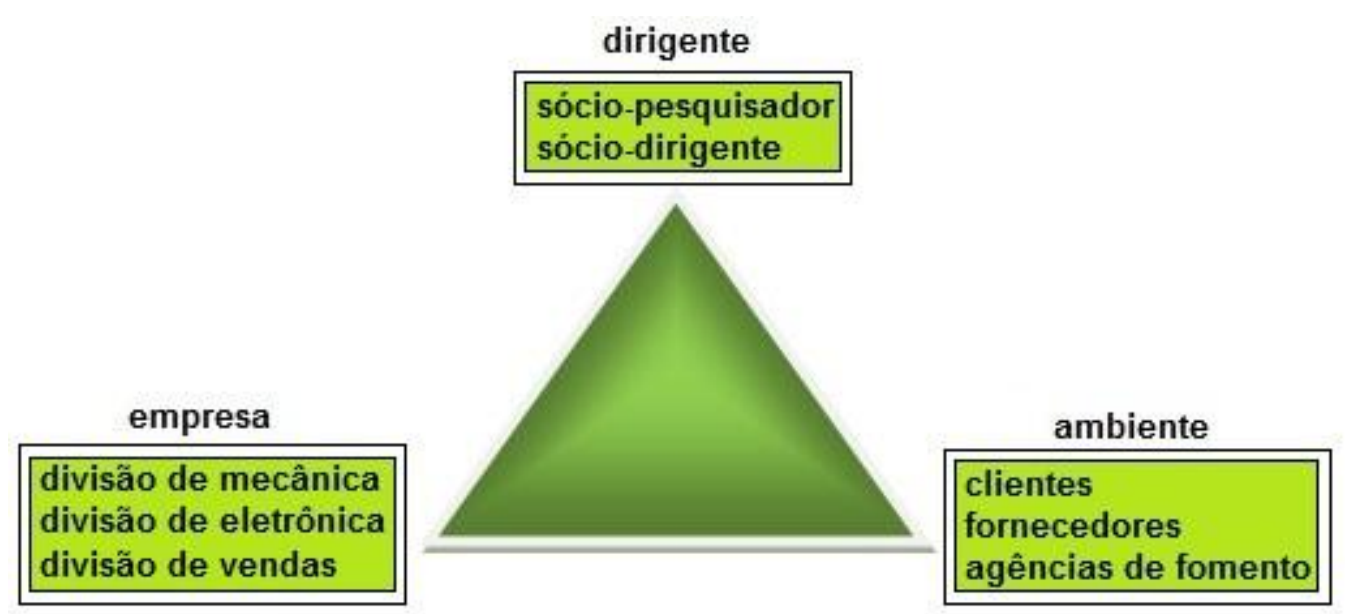

Figura 6.1 - Os atores das três dimensões da pequena empresa estudada

A empresa possui interações fortes entre a dimensão dirigente e a dimensão ambiente, representadas 1) pelas interações entre ambos os sócios e os órgãos de fomento, que, além de viabilizar a empresa economicamente, auxiliam na estruturação de planos de negócios e no desenvolvimento de novos produtos; e 2) pelas interações entre o sócio-dirigente e os clientes da empresa (geralmente professores universitários), que ajudam a definir os caminhos do desenvolvimento de produtos. As interações entre os sócios e seus fornecedores são fracas, porém as interações de um sócio com o outro são extremamente fortes.

Entre a dimensão dirigente e a dimensão empresa há uma interação muito forte entre o sócio-dirigente e todos os funcionários, das três divisões. O sócio-pesquisador quase não interage com os funcionários. Já as divisões de mecânica e eletrônica interagem fortemente entre si, mas ambas interagem de maneira fraca com a divisão de vendas.

Por fim, entre a dimensão empresa e a dimensão ambiente há interações fracas, primariamente pelo contato da divisão de mecânica com fornecedores, e interações mais fortes, primariamente pelo contato da divisão de vendas com os clientes. Entre fornecedores, clientes e órgãos de fomento não há interação específica no que diz respeito a esse caso.

Assim, podemos traçar a seguir o mapa de interações entre os atores do caso, representadas por três tipos de linhas: 1) as linhas mais grossas, verdes, representam as interações mais intensas, que representam troca e construção conjunta de conhecimentos; 2) as linhas finas e vermelhas representam interações que ocorrem com alguma frequência, mas que nem sempre representam troca e construção conjunta de conhecimentos e 3) a linha mais fina e preta representa possibilidades de interações que são pouco exploradas. A Figura 6.2 mostra o mapa completo das interações entre os atores do caso. 


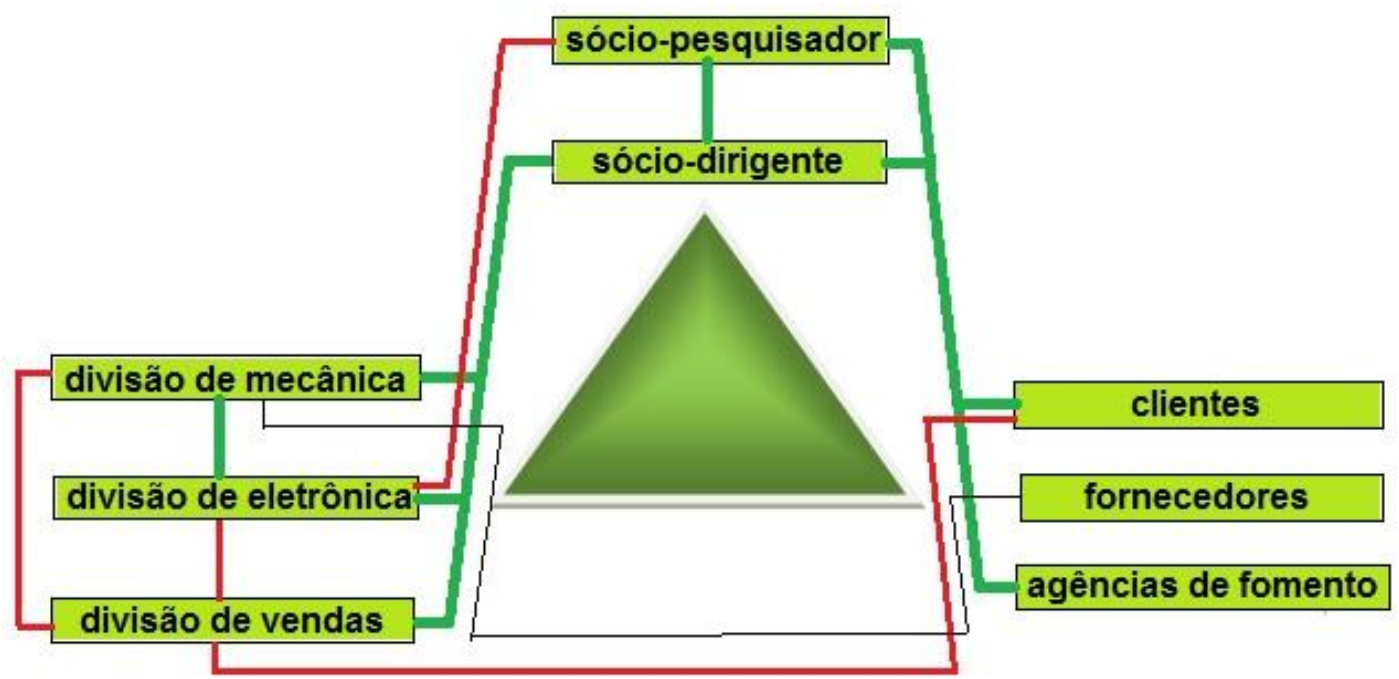

Figura 6.2 - Mapa de interações

Depois de traçadas as interações é possível verificar, dentro do mapa conceitual de aprendizagem nas pequenas empresas, quais "lados do triângulo" contêm as interações mais fortes e quais contêm as interações mais fracas. Se em algum lado do triângulo for encontrada uma interação forte é sinal de que há trocas de informação e construção de conhecimento entre as duas dimensões que formam o "triângulo". O próximo passo, portanto, é a finalização do mapa de aprendizagem organizacional desse caso, ilustrado na Figura 6.3.

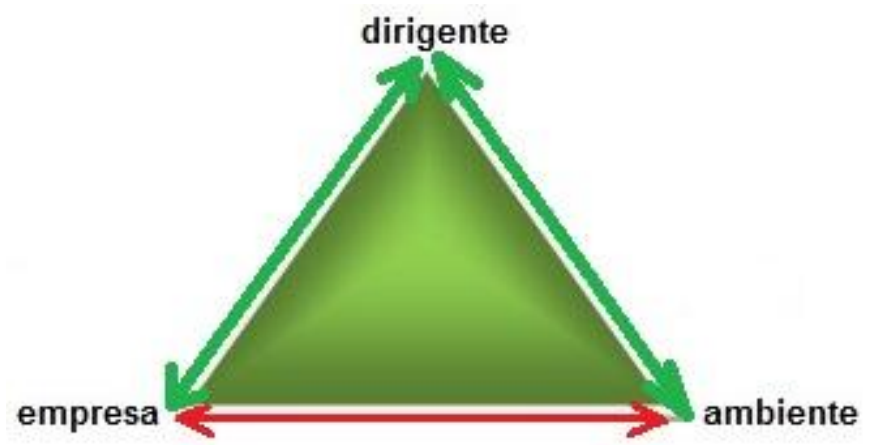

Figura 6.3 - Mapa de aprendizagem da empresa estudada

O mapa de aprendizagem final produzido para a empresa indica duas arestas de aprendizagem organizacional fortes, resultado das interações dirigente - ambiente e dirigente empresa, e uma aresta de aprendizagem organizacional fraca, resultado das interações empresa-ambiente.

O mapa resultante é coerente com o mapa conceitual teórico, verificando os construtos propostos. A presença de duas arestas fortes e uma fraca indica a possibilidade de inovação, com presença de aprendizagem horizontal. A ausência da terceira aresta poderia indicar dificuldade em introduzir produtos revolucionários ou de definir tendências de 
mercado, o que também é compatível com a situação da empresa: no momento ela está atendendo a demandas bastante flexíveis, fornecendo projetos customizados, mas suas inovações basicamente seguem o mercado, em resposta a demandas de clientes. Há ainda um outro fator priorizando a aprendizagem vertical: a empresa está procurando estabelecer linhas de produtos para fabricação em massa de um produto específico, uma cicladora. Isso implica a priorização do desempenho e não da variedade, e também condiz com o mapa conceitual.

Para finalizar, ficou claro que as interações propriamente ditas terão que ser estudadas num momento futuro. Há um número de interações muito elevado dentro da empresa (duas arestas fortes), com troca de informações a todo momento, mas nem todas representam troca de conhecimento. As interações sociais são centralizadas em torno de afinidades pessoais (nesse caso, pescaria e carros) e geram bom convívio social, talvez facilitando as demais interações. Mas há um outro tipo de interação, gerada durante a solução conjunta de problemas, que depende da "credibilidade" dos envolvidos, ou na confiança que o interlocutor parece possuir em na capacidade técnica de quem fala. Ideias e soluções são apresentadas, mas, nesse tipo de interação, parece haver um certo limiar de confiança para que essas ideias e soluções sejam acatadas.

Por isso fica claro que o mapa conceitual não se esgota por aqui, e seu futuro desenvolvimento depende da exploração mais aprofundada dessas interações entre os atores envolvidos na aprendizagem. No último capítulo, a seguir, serão apresentadas as conclusões finais do trabalho e as indicações de possíveis caminhos para o futuro desenvolvimento desse mapa conceitual como uma ferramenta prática. 


\section{Conclusões}

Os construtos propostos no mapa conceitual inicial, de aprendizagem vertical e aprendizagem horizontal, foram verificados empiricamente, em dois níveis. Primeiramente, os elementos que compõe cada construto foram encontrados na prática. Assim, em situações de aprendizagem vertical vividas pela empresa verifica-se a formalização dos processos, com o processo de memória organizacional, a hierarquia é obedecida, com uma cadeia de comando mais centralizada, a especialização aumenta, com a preponderância de trabalhos individuais nos quais o conhecimento técnico não é compartilhado, há menor vulnerabilidade em relação à rotatividade de pessoal, o tamanho tem um impacto menor, pois as atividades são individualizadas e as decisões são centralizadas, o que faz com que a tecnologia organizacional tenha menor impacto, há menor permeabilidade ao ambiente, há centralização de metas e a cultura mais comum é a de laço simples.

Inversamente, nas situações de aprendizagem horizontal a formalização de processos se reduz, a hierarquia se "achata", a especialização diminui, com a preponderância de trabalhos interdisciplinares ou em equipe, a centralização se reduz, com aumento de autonomia das pessoas envolvidas diretamente nos processos, há troca de conhecimento técnico pautada pela "credibilidade" do interlocutor, há maior vulnerabilidade em relação à rotatividade de pessoal, o tamanho tem maior impacto, pois influi nas interações entre os membros da empresa, o mesmo acontecendo com a tecnologia organizacional, que facilitará ou não o fluxo de informações, há maior permeabilidade em relação ao ambiente, as metas são compartilhadas e prevalece a cultura de laço duplo.

Em segundo lugar, a interdependência dos elementos de cada construto foi verificada, já que não foram identificadas situações em que um elemento tenha surgido sem a presença dos demais. Isso terá implicações futuras para o uso do mapa conceitual como uma ferramenta, já que a consequência da interdependência dos elementos é que o gerenciamento de um deles impactará todos os demais. Um caso único, entretanto, não é suficiente para que esta interdependência possa ser afirmada. Assim, um dos desenvolvimentos futuros para essa pesquisa é a ampliação do número de casos pesquisados, para verificação da interdependência dos elementos dos construtos de aprendizagem vertical e de aprendizagem horizontal.

Da mesma forma, é preciso desenvolver com maior profundidade o mapa conceitual de aprendizagem organizacional na pequena empresa. Um modelo inicial para o mapeamento 
da aprendizagem na pequena empresa foi proposto e executado, mas ainda precisa ser melhor desenvolvido em função das questões levantadas em campo, como veremos a seguir.

\subsection{Formação do mapa conceitual}

Um modelo para a construção do mapa conceitual de aprendizagem na pequena empresa foi utilizado, composto por 5 etapas:

i) definição dos atores nas três dimensões, dirigente, empresa e ambiente, como na Figura 7.1:

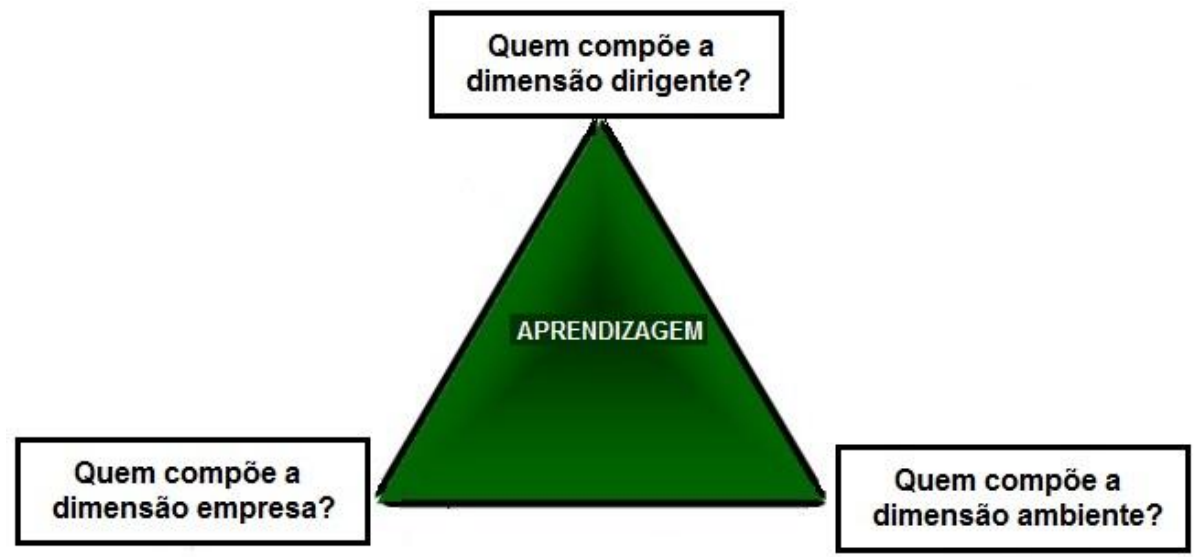

Figura 7.1 - Primeira etapa na construção do mapa de aprendizagem

ii) definição das interações entre os atores, como na Figura 7.2:

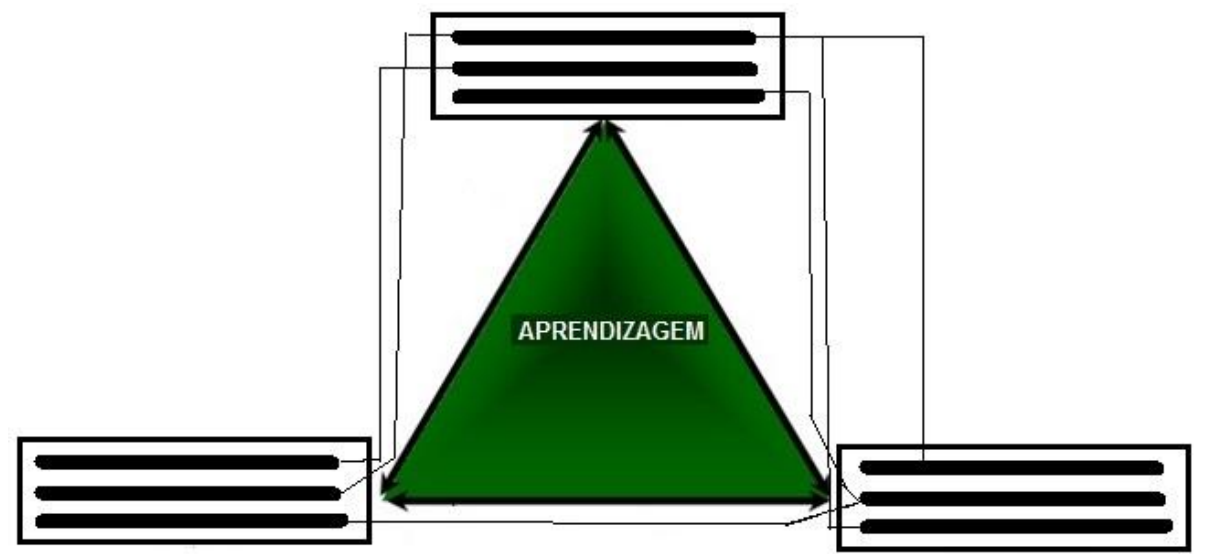

Figura 7.2 - Segunda etapa na construção do mapa de aprendizagem 
iii) definição da intensidade e/ou efetividade das interações, como na Figura 7.3:

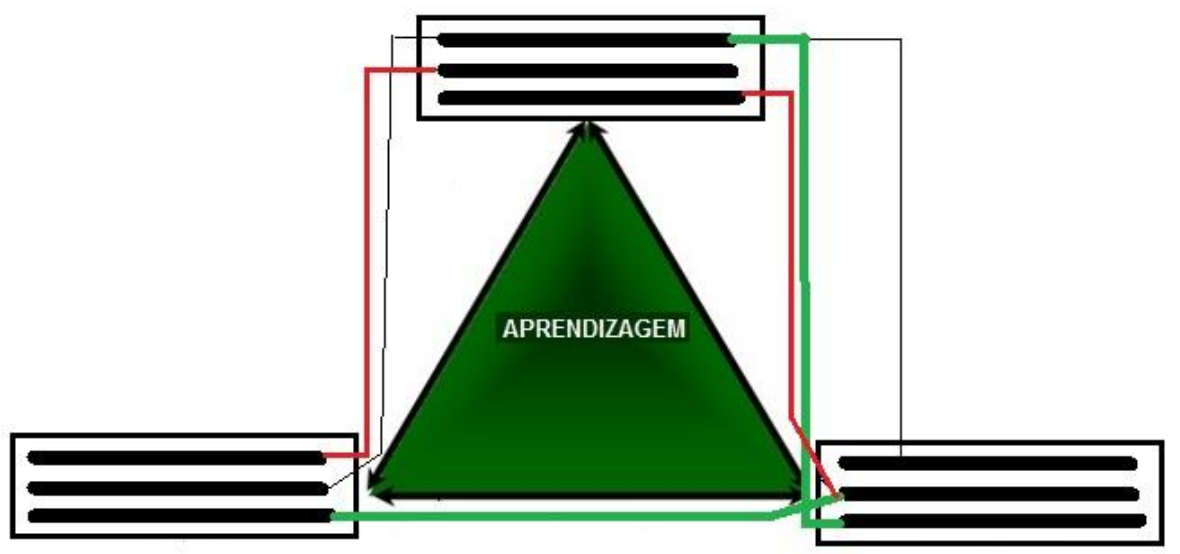

Figura 7.3 - Terceira etapa na construção do mapa de aprendizagem

iv) construção do mapa resumido, como na Figura 7.4 (cada aresta é representada pela interação mais forte encontrada):

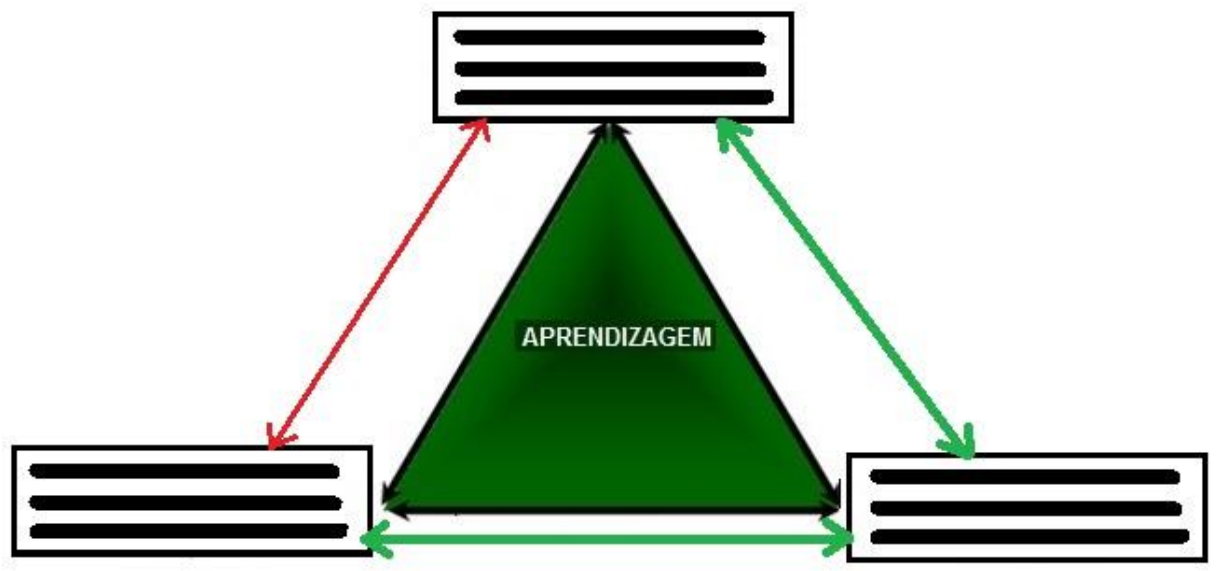

Figura 7.4 - Quarta etapa na construção do mapa de aprendizagem

v) análise e diagnóstico, de acordo com o Quadro 7.1:

\begin{tabular}{|l|l|}
\hline \multicolumn{1}{|c|}{ Resultado } & \multicolumn{1}{c|}{ Significado } \\
\hline nenhuma aresta forte & $\begin{array}{l}\text { a empresa não apresenta oportunidades de aprendizagem } \\
\text { organizacional e encontra-se estagnada, com dificuldades de reagir a } \\
\text { quaisquer mudanças em seu ambiente. }\end{array}$ \\
\hline uma única aresta forte & $\begin{array}{l}\text { a empresa apresenta apenas aprendizagem vertical, com forte foco em } \\
\text { desempenho. Isso pode acontecer em momentos de lançamento de } \\
\text { uma linha de produtos, por exemplo. Essa empresa responde às } \\
\text { alterações do ambiente em que está inserida, mas dificilmente } \\
\text { provocará mudanças nele. }\end{array}$ \\
\hline duas arestas fortes & $\begin{array}{l}\text { a empresa apresenta aprendizagem horizontal e aprendizagem } \\
\text { vertical, mas a segunda é a que prevalece. Novamente, o foco é o } \\
\text { desempenho, como no momento de colocar um produto em linha de } \\
\text { produção ou de implementar um novo processo. Essa situação foi a } \\
\text { encontrada no caso estudado. }\end{array}$ \\
\hline
\end{tabular}

Quadro 7.1 - Análise e diagnóstico do mapa de aprendizagem 


\begin{tabular}{|c|l|}
\hline \multicolumn{1}{|c|}{ Resultado } & \multicolumn{1}{c|}{ Significado } \\
\hline três arestas fortes & $\begin{array}{l}\text { A empresa possui um forte foco em variabilidade, com forte } \\
\text { preponderância de aprendizagem horizontal. Isso acontece durante o } \\
\text { desenvolvimento de um novo produto ou processo, por exemplo. }\end{array}$ \\
\hline
\end{tabular}

Quadro 7.1 - Análise e diagnóstico do mapa de aprendizagem (continuação)

\subsection{Diretrizes para aprimoramento do mapa conceitual}

Desde a etapa de entrevistas com o sócio-dirigente ficou clara a importância da estratégia na implementação dos diferentes tipos de aprendizagem na empresa. Isso significa que o modelo deve aprofundar sua descrição do papel da estratégia. Não ficou claro no caso se todos os dados colhidos foram um resultado direto da estratégia implementada na empresa, ou se a estratégia contribuiu para que as interações efetivamente acontecessem.

Além disso, apesar de haver coerência interna na proposição da interrelação entre os fatores de hierarquia, centralização, especialização, cultura, resultado e efeito, essa relação precisa ser melhor entendida e descrita, com o estudo de outros casos. Os próximos estudos deverão procurar outros casos, com diferentes trajetórias, e verificar se esta interrelação se mantém e se pode ser melhor descrita.

Outro fator que foi difícil de explorar na construção do mapa foi o tamanho da empresa, já que uma empresa com apenas 7 pessoas fornece proximidade suficiente entre as três dimensões, dirigente, ambiente e empresa, para que o tamanho não seja um fator

significativo. É necessário, portanto, que sejam estudados casos em empresas maiores (com dezenas de funcionários, por exemplo) para melhor verificação desse componente.

Por fim, as próprias interações que compõem o mapa conceitual de aprendizagem organizacional na pequena empresa devem ser melhor exploradas. O que determina a "credibilidade" da interação? Há fatores que determinam a efetividade de uma interação para que ela gere aprendizado? Uma interação social pode gerar aprendizagem? A verificação das interações em campo comprovou que os subprocessos estudados na literatura são encontrados em abundância no dia-a-dia da empresa; resta saber em que situações eles são realmente efetivos. 


\subsection{Considerações finais}

O presente trabalho foi proposto como um estudo qualitativo. Dessa forma, a pesquisa em campo foi realizada como uma complementação da proposta, com o objetivo de verificação preliminar da adequação dos construtos propostos. Os métodos adotados (estudo de caso único com relato de caso) refletem essa intenção de verificação preliminar.

A intenção desse trabalho foi propor uma base conceitual para futuros estudos, contemplando inclusive a lacuna de estudos empíricos que existe na literatura, conforme os dados apresentados na Introdução. Embora o interesse sobre o assunto seja crescente e as pressões por inovação sejam cada vez maiores, ainda há poucas soluções práticas e poucos trabalhos empíricos propostos pela academia em relação ao assunto. $\mathrm{O}$ mapa foi construído. Agora há necessidade de "navegar" com ele. Sua utilidade só será confirmada dessa forma.

Futuros desenvolvimentos devem contemplar estudos longitudinais, em empresas de base tecnológica com perfis diversos em termos de número de funcionários, tempo de operação e posição no mercado e, principalmente, verificar a utilidade prática do mapa conceitual como ferramenta de apoio à gestão para o dirigente da pequena empresa. 


\section{Apêndice A. Aprendizagem Organizacional: "Vulcão Verde" da Produção Internacional - Artigos Selecionados}

\begin{tabular}{|c|c|c|c|c|c|c|c|c|c|c|}
\hline Autor & Fonte & Ano & \# Cit. & $\begin{array}{l}\text { I. F. } \\
\text { (JCR) }\end{array}$ & $\begin{array}{l}\text { 5-Y I. F. } \\
\text { (JCR) }\end{array}$ & Média & $\begin{array}{l}\text { Índice de } \\
\text { Relevância }\end{array}$ & $\begin{array}{c}\text { Título } \\
\text { (Hiperlink) }\end{array}$ & Metodologia & Informações Básicas \\
\hline $\begin{array}{l}\text { Nonaka, I. } \\
\text { Toyama, R. }\end{array}$ & $\begin{array}{l}\text { Long range } \\
\text { planning }\end{array}$ & 2000 & 1.528 & 1,580 & 1,969 & 1,775 & 2.711 & $\begin{array}{l}\frac{\text { SECl, Ba and leadership: a }}{\text { unified model of dynamic }} \\
\text { knowledge creation }\end{array}$ & $?$ & $\begin{array}{l}\text { knowledge creation process is } \\
\text { a spiral; model }\end{array}$ \\
\hline Szulanski, G. & $\begin{array}{l}\text { Organizational } \\
\text { Behavior and } \\
\text { Human Decision } \\
\text { Processes }\end{array}$ & 2000 & 778 & 2,549 & 3,613 & 3,081 & 2.397 & $\begin{array}{l}\text { The Process of Knowledge } \\
\text { Transfer: A Diachronic } \\
\text { Analysis of Stickiness }{ }^{*} 1\end{array}$ & Quanti/survey & $\begin{array}{l}\text { process model of knowledge } \\
\text { transfer }\end{array}$ \\
\hline $\begin{array}{l}\text { Cross, R. } \\
\text { Parker, A. } \\
\text { Prusak, L. }\end{array}$ & $\begin{array}{l}\text { Organizational } \\
\text { Dynamics }\end{array}$ & 2001 & 369 & 0,607 & 1,310 & 0,959 & 354 & $\begin{array}{l}\text { Knowing what we know:- } \\
\text { Supporting knowledge } \\
\text { creation and sharing in social } \\
\underline{\text { networks }}\end{array}$ & Interviews & $\begin{array}{l}\text { ways to promote knowledge } \\
\text { creation and transfer in } \\
\text { networks of employees }\end{array}$ \\
\hline $\begin{array}{l}\text { Gold, A. H. } \\
\text { Malhotra, A. }\end{array}$ & $\begin{array}{l}\text { Journal of } \\
\text { Management } \\
\text { Information } \\
\text { Systems }\end{array}$ & 2001 & 952 & 2,098 & 3,215 & 2,657 & 2.529 & $\begin{array}{l}\text { Knowledge management: An } \\
\text { organizational capabilities } \\
\text { perspective }\end{array}$ & Quanti/survey & $\begin{array}{l}\text { organizational capabilities } \\
\text { (infra-structure and } \\
\text { processes) to implement KM }\end{array}$ \\
\hline King, W. R. & $\begin{array}{l}\text { Information } \\
\text { Systems } \\
\text { Management }\end{array}$ & 2001 & 83 & 0,010 & 0,010 & 0,010 & 1 & $\begin{array}{l}\text { Strategies for creating a } \\
\text { learning organization }\end{array}$ & P. B.? & $\begin{array}{l}\text { working definition of a learning } \\
\text { organization } \\
\text { six strategies for creating one }\end{array}$ \\
\hline Örtenblad, A. & $\begin{array}{l}\text { Learning } \\
\text { Organization }\end{array}$ & 2001 & 83 & 0,010 & 0,010 & 0,010 & 1 & $\begin{array}{l}\text { On differences between } \\
\text { organizational learning and } \\
\text { learning organization }\end{array}$ & P. B. & $\begin{array}{l}\text { OL } \times \text { Learning Organizations } \\
\text { (conceptual paper) } \\
\text { traditional and a social } \\
\text { perspective of organizational } \\
\text { learning + entities of learning } \\
\text { and knowledge location }\end{array}$ \\
\hline
\end{tabular}




\begin{tabular}{|c|c|c|c|c|c|c|c|c|c|c|}
\hline Autor & Fonte & Ano & \# Cit. & $\begin{array}{l}\text { I. F. } \\
\text { (JCR) }\end{array}$ & $\begin{array}{l}\text { 5-YI.F. } \\
\text { (JCR) }\end{array}$ & Média & $\begin{array}{l}\text { Índice de } \\
\text { Relevância }\end{array}$ & $\begin{array}{c}\text { Título } \\
\text { (Hiperlink) }\end{array}$ & Metodologia & Informações Básicas \\
\hline $\begin{array}{l}\text { Bontis, N. } \\
\text { Crossan, M. M. }\end{array}$ & $\begin{array}{l}\text { Journal of } \\
\text { Management } \\
\text { Studies }\end{array}$ & 2002 & 446 & 2,805 & 4,178 & 3,492 & 1.557 & $\begin{array}{l}\text { Managing an organizational } \\
\text { learning system by aligning } \\
\text { stocks and flows }\end{array}$ & ? & $\begin{array}{l}\text { OL x performance } \\
\text { stocks and flows of learning } \\
\text { across levels }\end{array}$ \\
\hline $\begin{array}{l}\text { Robey, D. } \\
\text { Ross, J. }\end{array}$ & $\begin{array}{l}\text { Journal of } \\
\text { Management } \\
\text { Information } \\
\text { Systems }\end{array}$ & 2002 & 461 & 2,098 & 3,215 & 2,657 & 1.225 & $\begin{array}{l}\text { Learning to implement } \\
\text { enterprise systems: an } \\
\text { exploratory study of the } \\
\text { dialectics of change }\end{array}$ & Case study & $\begin{array}{l}\text { comparative case study of } 13 \\
\text { industrial firms that } \\
\text { implemented an enterprise } \\
\text { resource planning (ERP) } \\
\text { system }\end{array}$ \\
\hline Lee, $\mathrm{H}$. & $\begin{array}{l}\text { Journal of } \\
\text { Management } \\
\text { Information } \\
\text { Systems }\end{array}$ & 2003 & 436 & 2,098 & 3,215 & 2,657 & 1.158 & $\begin{array}{l}\text { Knowledge management } \\
\text { enablers, processes, and } \\
\text { organizational performance: } \\
\text { An integrative view and } \\
\text { empirical examination }\end{array}$ & Quanti/survey & $\begin{array}{l}\text { relationship between } \\
\text { knowledge management } \\
\text { factors such as enablers, } \\
\text { processes, and performance }\end{array}$ \\
\hline Antonacopoulou, E. P. & $\begin{array}{l}\text { Management } \\
\text { Learning }\end{array}$ & 2006 & 58 & 1,133 & 2,056 & 1,595 & 92 & $\begin{array}{l}\text { The relationship between } \\
\text { individual and organizational } \\
\text { learning: New evidence from } \\
\text { managerial learning practices }\end{array}$ & ? & $\begin{array}{l}\text { individual } \mathrm{x} \text { organizational } \\
\text { learning }\end{array}$ \\
\hline Gourlay, S. & $\begin{array}{l}\text { Journal of } \\
\text { Management } \\
\text { Studies }\end{array}$ & 2006 & 79 & 2,805 & 4,178 & 3,492 & 276 & $\begin{array}{l}\text { Conceptualizing Knowledge } \\
\text { Creation: A Critique of } \\
\text { Nonaka's Theory* }\end{array}$ & Conceitual & $\begin{array}{l}\text { opposing model: different } \\
\text { kinds of knowledge are } \\
\text { created by different kinds of } \\
\text { behaviour }\end{array}$ \\
\hline Levinthal, D. & $\begin{array}{l}\text { Organization } \\
\text { Science }\end{array}$ & 2006 & 122 & 3,126 & 5,777 & 4,452 & 543 & $\begin{array}{l}\text { Crossing an apparent chasm: } \\
\text { Bridging mindful and less- } \\
\text { mindful perspectives on } \\
\text { organizational learning }\end{array}$ & ? & mindfulness \\
\hline
\end{tabular}




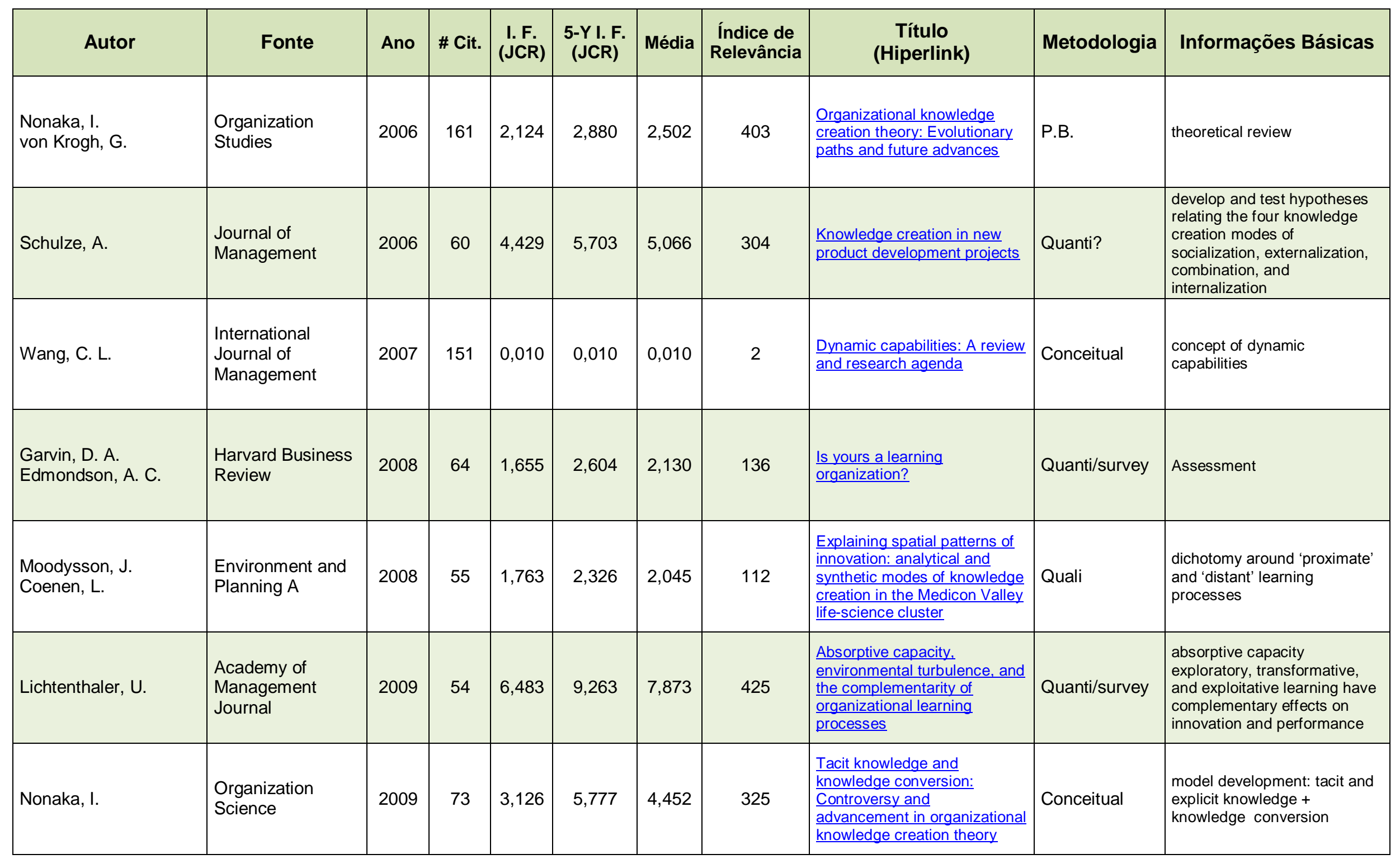




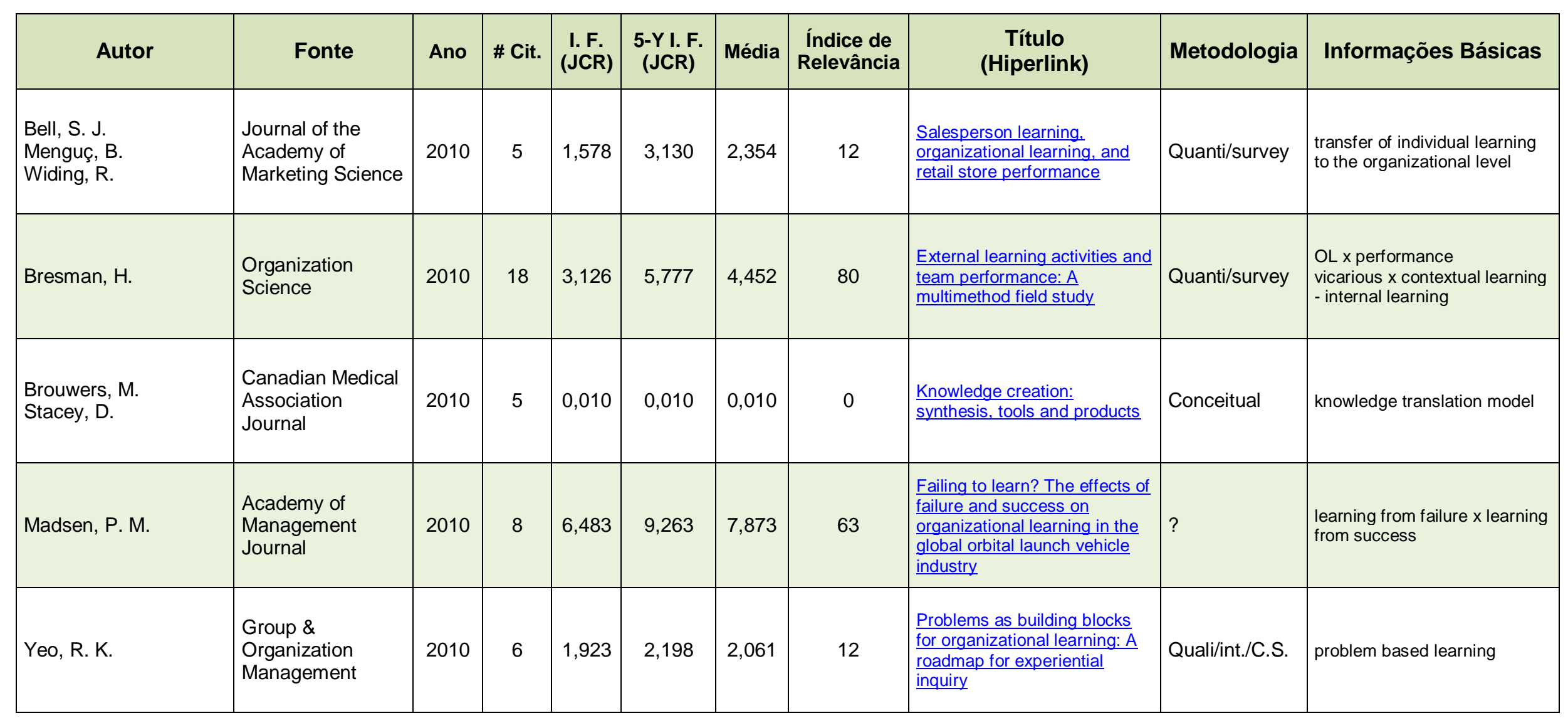


Apêndice B. Aprendizagem Organizacional: "Vulcão Verde" da Produção Brasileira - Artigos Selecionados

\begin{tabular}{|c|c|c|c|c|c|c|c|c|c|}
\hline Autor & Fonte & Ano & \# Cit. & Qualis & $\begin{array}{l}\text { Valor } \\
\text { Qualis }\end{array}$ & $\begin{array}{l}\text { Índice de } \\
\text { Relevância }\end{array}$ & $\begin{array}{c}\text { Título } \\
\text { (Hiperlink) }\end{array}$ & Metodologia & Informações Básicas \\
\hline Leite, J. B. D. & $\begin{array}{l}\text { Revista de } \\
\text { Administração } \\
\text { Contemporânea }\end{array}$ & 2003 & 31 & B1 & 5 & 155 & $\begin{array}{l}\text { Competição baseada em } \\
\frac{\text { competências e }}{\text { aprendizagem }} \\
\text { organizacional: em busca } \\
\text { da vantagem competitiva }\end{array}$ & $\begin{array}{l}\text { Estudo de } \\
\text { Caso }\end{array}$ & $\begin{array}{l}\text { proposta pedagógica } \\
\text { construtivista, com foco } \\
\text { na Andragogia, para a } \\
\text { eficácia dos processos de } \\
\text { criação de conhecimento } \\
\text { e da aprendizagem } \\
\text { organizacional }\end{array}$ \\
\hline $\begin{array}{l}\text { Shinyashiki, G. T } \\
\text { Trevizan, M. A. }\end{array}$ & $\begin{array}{l}\text { Revista Latino- } \\
\text { Americana de } \\
\text { Enfermagem }\end{array}$ & 2003 & 36 & B1 & 5 & 180 & $\begin{array}{l}\frac{\text { Sobre a criação ea gestão }}{\text { do conhecimento }} \\
\underline{\text { organizacional }}\end{array}$ & Conceitual & $\begin{array}{l}\text { o papel da enfermeira no } \\
\text { processo de gestão do } \\
\text { conhecimento, } \\
\text { posicionando-a na } \\
\text { interseção dos fluxos } \\
\text { horizontais e verticais de } \\
\text { informação, e na criação } \\
\text { de uma vantagem } \\
\text { competitiva sustentável }\end{array}$ \\
\hline Bastos, L. E. M. & $\begin{array}{l}\text { Diss. - UFBahia - } \\
\text { Adm }\end{array}$ & 2003 & 5 & 4 & 4 & 20 & $\begin{array}{l}\text { Avaliação do e-learning } \\
\text { corporativo no Brasil }\end{array}$ & & \\
\hline $\begin{array}{l}\text { Bido, D. S. } \\
\text { Godoy, A. S. } \\
\text { Araujo, B. F. V. B. }\end{array}$ & $\begin{array}{l}\text { RAM. Revista de } \\
\text { Administração } \\
\text { Mackenzie }\end{array}$ & 2010 & 1 & B1 & 5 & 5 & $\begin{array}{l}\text { Articulação entre as } \\
\text { aprendizagens individual, } \\
\text { grupal e organizacional: } \\
\text { um estudo no ambiente } \\
\text { industrial }\end{array}$ & Quanti/Survey & $\begin{array}{l}\text { articulação entre os níveis } \\
\text { individual, grupal e } \\
\text { organizacional da } \\
\text { aprendizagem }\end{array}$ \\
\hline
\end{tabular}


Apêndice C. Aprendizagem Organizacional na Pequena Empresa: "Vulcão Verde" da Produção Internacional Artigos Selecionados

\begin{tabular}{|c|c|c|c|c|c|c|c|c|c|c|}
\hline Autor & Fonte & Ano & \# Cit. & $\begin{array}{l}\text { I. F. } \\
\text { (JCR) }\end{array}$ & $\begin{array}{c}\text { 5-Y I. F. } \\
\text { (JCR) }\end{array}$ & Média & $\begin{array}{c}\text { Índice de } \\
\text { Relevância }\end{array}$ & $\begin{array}{c}\text { Título } \\
\text { (Hiperlink) }\end{array}$ & Metodologia & Informações Básicas \\
\hline $\begin{array}{l}\text { Chaston, I. } \\
\text { Badger, B. }\end{array}$ & $\begin{array}{l}\text { European Journal } \\
\text { of Marketing }\end{array}$ & 2000 & 25 & 0,756 & 0,030 & 0,393 & 10 & $\begin{array}{l}\text { Organizational learning style } \\
\text { and competences: a } \\
\text { comparative investigation of } \\
\text { relationship and } \\
\text { transactionally orientated } \\
\text { small UK manufacturing firms } \\
\end{array}$ & Quanti/Survey & $\begin{array}{l}\text { survey of learning style and } \\
\text { perception of competences } \\
\text { relative to competitors in } \\
\text { small manufacturing firms }\end{array}$ \\
\hline Corti, E. & $\begin{array}{l}\text { Enterprise and } \\
\text { Innovation } \\
\text { Management } \\
\text { Studies }\end{array}$ & 2000 & 13 & 0,030 & 0,030 & 0,030 & 0 & $\begin{array}{l}\text { Knowledge creation in small } \\
\text { manufacturing firms during } \\
\text { product innovation: an } \\
\text { empirical analysis of cause- } \\
\text { effect relationships among its } \\
\text { determinants }\end{array}$ & Quanti/Survey & $\begin{array}{l}\text { influence of cognitive, social } \\
\text { and management } \\
\text { environment during technical } \\
\text { problem-solving have on the } \\
\text { generation of new knowledge } \\
\text { in small manufacturing firms }\end{array}$ \\
\hline $\begin{array}{l}\text { Kautz, K. } \\
\text { Thaysen, K. }\end{array}$ & OR Insight & 2002 & 4 & 0,030 & 0,030 & 0,030 & 0 & $\begin{array}{l}\text { Knowledge creation and IT } \\
\text { systems in a small software } \\
\text { firm }\end{array}$ & Quali? & $\begin{array}{l}\text { use of IT was intended to } \\
\text { support and facilitate learning } \\
\text { and knowledge creation } \\
\text { rather than to regulate these } \\
\text { processes }\end{array}$ \\
\hline Basly, S. & $\begin{array}{l}\text { European } \\
\text { Academy of } \\
\text { Management }\end{array}$ & 2007 & 0 & 0,030 & 0,030 & 0,030 & 0 & $\begin{array}{l}\text { Organizational learning and } \\
\text { knowledge development } \\
\text { peculiarities in Small and } \\
\text { Medium Family Enterprises } \\
\end{array}$ & Conceitual & $\begin{array}{l}\text { processes of organizational } \\
\text { learning and knowledge } \\
\text { development within the small } \\
\text { and medium sized family firm }\end{array}$ \\
\hline $\begin{array}{l}\text { Cegarra-Navarro, J. G. } \\
\text { Jimenez, D. J. }\end{array}$ & $\begin{array}{l}\text { International } \\
\text { Journal of } \\
\text { Information } \\
\text { Management }\end{array}$ & 2007 & 5 & 0,723 & 1,243 & 0,983 & 5 & $\begin{array}{l}\frac{\text { Implementing e-business }}{\text { through organizational }} \\
\text { learning: An empirical } \\
\text { investigation in SMEs }\end{array}$ & Quanti/Survey & $\begin{array}{l}\text { importance and significance } \\
\text { of Huber's processes on four } \\
\text { different levels of e-business }\end{array}$ \\
\hline Spraggon, M. & $\begin{array}{l}\text { Management } \\
\text { Research News }\end{array}$ & 2008 & 4 & 0,030 & 0,030 & 0,030 & 0 & $\begin{array}{l}\text { Knowledge creation } \\
\text { processes in small innovative } \\
\text { hi-tech firms }\end{array}$ & Quali & $\begin{array}{l}\text { specific action and interaction } \\
\text { processes aiming at creating } \\
\text { knowledge }\end{array}$ \\
\hline
\end{tabular}




\begin{tabular}{|c|c|c|c|c|c|c|c|c|c|c|}
\hline Autor & Fonte & Ano & \# Cit. & $\begin{array}{l}\text { I. F. } \\
\text { (JCR) }\end{array}$ & $\begin{array}{l}\text { 5-Y I. F. } \\
\text { (JCR) }\end{array}$ & Média & $\begin{array}{c}\text { Índice de } \\
\text { Relevância }\end{array}$ & $\begin{array}{c}\text { Título } \\
\text { (Hiperlink) }\end{array}$ & Metodologia & Informações Básicas \\
\hline Leach, T. & $\begin{array}{l}\text { Research in Post- } \\
\text { Compulsory } \\
\text { Education }\end{array}$ & 2010 & 1 & 0,030 & 0,030 & 0,030 & 0 & $\begin{array}{l}\text { Knowledge creation and } \\
\text { deployment in the small, but } \\
\text { growing, enterprise and the } \\
\text { psychological contract }\end{array}$ & $?$ & $\begin{array}{l}\text { processes of knowledge } \\
\text { creation and deployment } \\
\text { within the small, but growing, } \\
\text { enterprise }\end{array}$ \\
\hline $\begin{array}{l}\text { Lopez-Nicolas, C. } \\
\text { Soto-Acosta, P. }\end{array}$ & $\begin{array}{l}\text { International } \\
\text { Journal of } \\
\text { Information } \\
\text { Management }\end{array}$ & 2010 & 1 & 0,723 & 1,243 & 0,983 & 1 & $\begin{array}{l}\text { Analyzing ICT adoption and } \\
\text { use effects on knowledge } \\
\text { creation: An empirical } \\
\text { investigation in SMEs }\end{array}$ & Quanti/Survey & $\begin{array}{l}\text { adoption and use of } \\
\text { information and } \\
\text { communication technology } \\
\text { (ICT) on organizational } \\
\text { learning (OL) - SECl model }\end{array}$ \\
\hline
\end{tabular}




\section{REFERÊNCIAS}

ANPEI (2010). Brasil despenca para o $6^{\circ}$ lugar no ranking de inovação. Disponível em: <http://www.anpei.org.br/imprensa/noticias/brasil-despenca-para-o-68\%C2\%BA-lugar-noranking-de-inovacao>. Acesso em: 13 dez. 2010.

ANTONACOPOULOU, E. P. (2006). The Relationship between Individual and Organizational Learning: New Evidence from Managerial Learning Practices. Management Learning, v.37, n.4, p.455-473, December 1, 2006.

ARGOTE, L.; MIRON-SPEKTOR, E. (2010). Organizational learning: From experience to knowledge. Organization Science.

ARGYRIS, C. (1977). Organizational learning and management information systems. Accounting, Organizations and Society, v.2, n.2, p.113-123.

ARGYRIS, C.; SCHÖN, D. A. (1996). Organizational Learning II: Theory, Method and Practice. Addison-Wesley.

BALESTRIN, A.; VARGAS, L. M.; FAYARD, P. (2008). Knowledge creation in small-firm network. Journal of Knowledge Management, v.12, n.2, p.94 - 106.

BARNETT, W.; HANSEN, M. (1996). The red queen in organizational evolution. Strategic Management Journal, v.17, n.S1, p.139-157.

BASLY, S. (2007a). The internationalization of family SME: An organizational learning and knowledge development perspective. Baltic Journal of Management, v.2, n.2, p.154 - 189.

. (2007b). Organizational learning and knowledge development peculiarities in Small and Medium Family Enterprises.

BASTOS, A. et al. (2004). Aprendizagem organizacional versus organizações que aprendem: características e desafios que cercam essas duas abordagens de pesquisa. Rev Adm USP, v.39, n.3, p.220-30.

BATHELT, H.; MALMBERG, A.; MASKELL, P. (2004). Clusters and knowledge: local buzz, global pipelines and the process of knowledge creation. Progress in Human Geography, v.28, n.1, p.31-56, February 1, 2004.

BELL, S. J.; MENGUÇ, B.; WIDING, R. E. (2010). Salesperson learning, organizational learning, and retail store performance. Journal of the Academy of Marketing Science, v.38, n.2, p.187-201.

BIDO, D. S. et al. (2010). Articulação entre as aprendizagens individual, grupal e organizacional: um estudo no ambiente industrial. RAM. Revista de Administração Mackenzie (Online), v.11, p.68.

BOLLINGER, L. et al (1983). A review of literature and hypotheses on new technologybased firms. Research Policy, v. 12, p. 1 - 14. 
BONTIS, N.; CROSSAN, M. M.; HULLAND, J. (2002). Managing an organizational learning system by aligning stocks and flows. Journal of Management Studies, v.39, n.4, p.437-469.

BORRELLI, F. et al. (2005). Inter-Organizational Learning and Collective Memory in Small Firms Clusters: an Agent-Based Approach. Journal of Artificial Societies and Social Simulation, v.8, n.3, p.4.

BRASIL (2012). Mapa das micro e pequenas empresas. Disponível em: <http://www.brasil.gov.br/empreendedor/empreendedorismo-hoje/o-mapa-das-micro-epequenas-empresas> Acesso em: 10 de agosto de 2012.

BRESMAN, H. (2010). External Learning Activities and Team Performance: A Multimethod Field Study. Organization Science, v.21, n.1, p.81-96.

BROUWERS, M.; STACEY, D.; O'CONNOR, A. (2010). Knowledge creation: synthesis, tools and products. CMAJ, v.182, n.2, p.E68-72, February 9, 2010.

BROWN, J. S.; DUGUID, P. (1998). Organizing Knowledge. California Management Review, v.40, n.3, p.90 - 112.

BROWN, M. M.; BRUDNEY, J. L. (2003). Learning organizations in the public sector? A study of police agencies employing information and technology to advance knowledge. Public administration review, v.63, n.1, p.30-43.

BULGACOV, S.; VERDU, F. C. (2001). Redes de pesquisadores da área de administração: um estudo exploratório. Revista de Administração Contemporânea, v.5, n.spe, p.163-182.

BURREll, G.; MORGAN, G. (1979). Sociological Paradigms and Organizational Analysis. Londres: Heinemann.

CARVALHO, K. C. (2010). A pequena empresa e seu ambiente organizacional: construção de um mapa das práticas dos dirigentes de uma empresa de tecnologia da informação com base na Teoria da Dependência de Recursos e na Teoria Institucional. (Doutorado) - Escola de Engenharia de São Carlos (EESC) - Departamento de Engenharia de Produção, Universidade de São Paulo (USP), São Carlos.

CEGARRA-NAVARRO, J. G. (2005). An empirical investigation of organizational learning through strategic alliances between SMEs. Journal of Strategic Marketing, v.13, n.1, p.3 16.

CEGARRA-NAVARRO, J. G.; DEWHURST, F. (2007). Linking organizational learning and customer capital through an ambidexterity context: an empirical investigation in SMEs. The International Journal of Human Resource Management, v.18, n.10, p.1720 - 1735.

CEGARRA-NAVARRO, J. G.; JIMÉNEZ, D. J.; MARTÍNEZ-CONESA, E. Á. (2007). Implementing e-business through organizational learning: An empirical investigation in SMEs. International Journal of Information Management, v.27, n.3, p.173-186. 
CÊRA, K.; ESCRIVÃO FILHO, E. (2003). Particularidades de gestão da pequena empresa: condicionantes ambientais, organizacionais e comportamentais do dirigente. Encontro de Estudos sobre Empreendedorismo e Gestão de Pequenas Empresas, EGEPE, v.3, p.796812.

CHASTON, I.; BADGER, B.; SADLER-SMITH, E. (2000). Organizational learning style and competences: A comparative investigation of relationship and transactionally orientated small UK manufacturing firms. European Journal of Marketing, v.34, n.5/6, p.625 - 642.

CHASTON, I.; BADGER, B.; SADLER SMITH, E. (2001). Organizational learning: an empirical assessment of process in small UK manufacturing firms. Journal of Small Business Management, v.39, n.2, p.139-151.

CHUA, A. L.; PAN, S. L. (2008). Knowledge transfer and organizational learning in IS offshore sourcing. Omega, v.36, n.2, p.267-281.

COCHIA, C. B. R.; MACHADO-DA-SILVA, C. L. (2004). Ambiente, interpretação e estratégia em organizações paranaenses dos setores de vestuário e alimentos. Revista de Administração Contemporânea, v.8, n.spe, p.11-35.

CORREIO do Estado (2010). Brasil será $7^{\mathbf{a}}$ economia em 2011, projeta Fundo Monetário Internacional. Disponível em: <http://www.correiodoestado.com.br/ noticias/brasil-sera-7-economia-em-2011-projeta-fundo-monetario-inter_83943>. Acesso em: 13 dez. 2010.

CORTI, E.; STORTO, C. (2000). Knowledge Creation in Small Manufacturing Firms During Product Innovation: An Empirical Analysis of Cause-effect Relationships Among its Determinants. Enterprise and Innovation Management Studies, v.1, n.3, p.245 - 263.

CRESWELL, J. (2007). Procedimentos Qualitativos. In: Projeto de pesquisa: métodos qualitativo, quantitativo e misto. 2.ed. Porto Alegre: Artmed. Cap.10, p.184 - 209.

CROSS, R. et al. (2001). Knowing what we know:-Supporting knowledge creation and sharing in social networks. Organizational dynamics, v.30, n.2, p.100-120.

CSASZAR, F. A.; SIGGELKOW, N. (2010). How Much to Copy? Determinants of Effective Imitation Breadth. Organization Science, v.21, n.3, p.661-676.

DAFT, R. L. (2002). Organizações e Teoria da Organização. In: Teoria e Projetos. São Paulo: Pioneira Thomson Learning. Cap.1, p.15 - 18.

Organizações -

DAILYMAIL (2011). Brazil overtakes UK as sixth biggest economy as Britain falls behind a South American nation for the first time. Disponível em: <http://www.dailymail.co.uk/news/article-2078596/Brazil-overtakes-UK-sixth-biggesteconomy-Britain-falls-South-American-nation-time.html>. Acesso em: 23 jun. 2012.

DAVILA, T.; EPSTEIN, M.; SHELTON, R. (2007). As Regras da Inovação. Porto Alegre: Bookman. 
DE CLERCQ, D.; SAPIENZA, H. J.; CRIJNS, H. (2003). The internationalization of small and medium-sized firms: the role of organizational learning effort and entrepreneurial orientation. Working Papers of Faculty of Economics and Business Administration, Ghent University, Belgium.

DE MOURA, M. C. C.; BITENCOURT, C. C. (2006). A articulação entre estratégia e o desenvolvimento de competências gerenciais.

DEAKINS, D.; FREEL, M. (1998). Entrepreneurial learning and the growth process in SMEs. The Learning Organization, v.5, n.3, p.144-155.

DEKKER, H. C.; ABBEELE, A. V. D. (2010). Organizational Learning and Interfirm Control: The Effects of Partner Search and Prior Exchange Experiences. Organization Science, v.21, n.6, p.1233-1250.

DRUCKER, P. (1981). Prática da administração de empresas. Cengage Learning Editores.

EASTERBY-SMITH, M.; CROSSAN, M.; NICOLINI, D. (2000). Organizational learning: debates past, present and future. Journal of Management Studies, v.37, n.6, p.783-796.

ENDEAVOR (2008). Falta de inovação trava avanço do Brasil. Disponível em: <http://www.endeavor.org.br/conteudo/artigos/falta-de-inovacao-trava-avanco-do-brasil >. Acesso em: 13 dez. 2010.

FANG, C.; LEE, J.; SCHILLING, M. A. (2010). Balancing Exploration and Exploitation Through Structural Design: The Isolation of Subgroups and Organizational Learning. Organization Science, v.21, n.3, p.625-642.

FERNANDES, D. V. D. H.; SANTOS, C. P. D. (2008). Orientação empreendedora: um estudo sobre as consequências do empreendedorismo nas organizações. RAE eletrônica, v.7, p.0.

FINEP (2010). Apresentação <http://www.finep.gov.br/programas/programas_ini.asp>. Acesso em: 15 dez. 2010.

FIORENTINI, D. (2008). A pesquisa e as práticas de formação de professores de matemática em face das políticas públicas no Brasil. Bolema: Mathematics Education Bulletin, v.21, n.29.

FLEURY, A.; FLEURY, M. (2001). Estratégias competitivas e competências essenciais: perspectivas para a internacionalização da indústria no Brasil. Gest. Prod, p.129-144.

FLEURY, A. C.; FLEURY, M. T. L. (1995). Os desafios da aprendizagem e inovação organizacional. RAE (Revista de Administração de Empresas), v.35, n.5, p.14 - 20.

FLEURY, M.; JÚNIOR, M. (2002). Aprendizagem e gestão do conhecimento. As pessoas na organizaçao, p.133. 
GARCÍA-MORALES, V. J.; LLORENS-MONTES, F. J.; VERDÚ-JOVER, A. J. (2006). Antecedents and consequences of organizational innovation and organizational learning in entrepreneurship. Industrial Management \& Data Systems, v.106, n.1, p.21-42.

GARCÍA-MORALES, V. J.; LLORÉNS-MONTES, F. J.; VERDÚ-JOVER, A. J. (2007). Influence of personal mastery on organizational performance through organizational learning and innovation in large firms and SMEs. Technovation, v.27, n.9, p.547-568.

GARVIN, D. A.; EDMONDSON, A. C.; GINO, F. (2008). Is yours a learning organization? Harvard Business Review, v.86, n.3, p.109.

GILES, C.; HARGREAVES, A. (2006). The Sustainability of Innovative Schools as Learning Organizations and Professional Learning Communities During Standardized Reform. Educational Administration Quarterly, v.42, n.1, p.124-156, February 1, 2006.

GOLD, A. H.; MALHOTRA, A.; SEGARS, A. H. (2001). Knowledge Management: An Organizational Capabilities Perspective. J. Manage. Inf. Syst., v.18, n.1, p.185-214.

GOURLAY, S. (2006). Conceptualizing Knowledge Creation: A Critique of Nonaka's Theory*. Journal of Management Studies, v.43, n.7, p.1415-1436.

GRAHAM, C. M.; NAFUKHO, F. M. (2007). Culture, organizational learning and selected employee background variables in small-size business enterprises. Journal of European Industrial Training, v.31, n.2, p.127 - 144.

GRAHAM, C. M.; NAFUKHO, F. M. (2008). Exploring organizational learning mechanisms in small-size business enterprises. http://education. fiu. edu/newhorizons, v.22, n.1, p.4.

GRAHAM, I. D. et al. (2006). Lost in knowledge translation: time for a map? Journal of Continuing Education in the Health Professions, v.26, n.1, p.13-24.

GRANSTRAND, O. (1998). Towards a theory of the technology-based firm. Research Policy, v. 27, p. 465 - 489.

GUPTA, V. K.; MOESEL, D. D. (2008). Promoting entrepreneurial orientation for new knowledge creation: trade-offs in customer alliances of smes in high (interactive paper). Frontiers of Entrepreneurship Research, v.28, n.19.

HITT, M. A. et al. (2000). Partner selection in emerging and developed market contexts: Resource-based and organizational learning perspectives. The Academy of Management Journal, v.43, n.3, p.449-467.

HORWITZ, S. (2010). The sensory order and organizational learning. The Social Science of Hayek's 'The Sensory Order'(Advances in Austrian Economics, Volume 13), Emerald Group Publishing Limited, v.13, p.263-284.

HUBER, G. (1991). Organizational learning: The contributing processes and the literatures. Organization science, v.2, n.1, p.88-115, Fevereiro. 
HURLEY, R.; HULT, G. (1998). Innovation, market orientation, and organizational learning: an integration and empirical examination. The Journal of Marketing, v.62, n.3, p.42-54.

IBGE (2003). As micro e pequenas empresas comerciais e de serviços no Brasil - 2001. Rio de Janeiro. Série Estudos e pesquisas, Informação econômica.

INSEAD (2011). INSEAD Issues: The Global Innovation Index 2011. Switzerland ranks first among 125 economies on innovation levels. Disponível em: <http://www.insead.edu/media_relations/press_release/2011_global_innovation_index.cfm>. Acesso em: 23 jun. 2012.

JANISSEK-MUNIZ, R. et al. (2005). Inteligência Estratégica Antecipativa e Coletiva (IEAc): transferência e adaptação de conhecimentos metodológicos visando propor soluções e promover a IEAc no Brasil. XXIX Encontro da Anpad (Enanpad), v.29.

JAVANMARD, H. A.; SKHAEI, F. (2009). Surveying the relation between personal skills, organizational innovation, learning and performance in small and medium size enterprises (smes) of the markazi province. Bassirat (in management), v.16(44), n.FALL 2009WINTER 2010, p.81 - 97.

JIANG, W.; JIE, L.; HAO, J. (2009). Learn-from-Agents Mode and Organizational Learning Performance:An Empirical Study of SMEs. Journal of Business Economics, v.7.

JOHANNESSEN, J.; OLSEN, B.; LUMPKIN, G. (2001). Innovation as newness: what is new, how new, and new to whom? European Journal of Innovation Management, v.4, n.1, p.20-31.

JONES, O.; MACPHERSON, A. (2006). Inter-Organizational Learning and Strategic Renewal in SMEs: Extending the 4I Framework. Long Range Planning, v.39, n.2, p.155175.

JULIEN, P.-A. (1997). Introdução: para uma definição das PME. In: . Lês PME bilan et perspectives. 2.ed. Québec: Economica.

KANG, S.-C.; MORRIS, S.; SNELL, S. (2007). Relational Archetypes, Organizational Learning, and Value Creation: Extending the Human Resource Architecture. The Academy of Management Review ARCHIVE, v.32, n.1, p.236-256.

KAUTZ, K.; THAYSEN, K.; THANNING VENDELO, M. (2002). Knowledge Creation and IT Systems in a Small Software Firm. ORI, v.15, n.2, p.11-17.

KING, W. R. (2001). Strategies for Creating A Learning Organization. Information Systems Management, v.18, n.1, p.1-9.

KLOTZLE, M. C. (2002). Alianças estratégicas: conceito e teoria. Revista de Administração contemporânea, v.6, n.1, p.85-104.

KONTOGHIORGHES, C.; AWBRE, S.; FEURIG, P. (2005). Examining the relationship between learning organization characteristics and change adaptation, innovation, and 
organizational performance. Human Resource Development Quarterly, v.16, n.2, p.185212.

KYRIAKIDOU, O.; GORE, J. (2005). Learning by example: Benchmarking organizational culture in hospitality, tourism and leisure SMEs. Benchmarking: An International Journal, v.12, n.3, p.192 - 206.

LADO, A.; WILSON, M. (1994). Human resource systems and sustained competitive advantage: A competency-based perspective. Academy of management review, v.19, n.4, p.699-727.

LAM, A. (2000). Tacit knowledge, organizational learning and societal institutions: an integrated framework. Organization studies, v.21, n.3, p.487-513.

LANG, J. R.; CALANTONE, R. J.; GUDMUNDSON, D. (1997). Small firm information seeking as a response to environmental threats and opportunities. Journal of Small Business Management, v.35, p.11-23.

LEACH, T. (2010). Knowledge creation and deployment in the small, but growing, enterprise and the psychological contract. Research in Post-Compulsory Education, v.15, n.3, p.329344.

LEE, H.; CHOI, B. (2003). Knowledge Management Enablers, Processes, and Organizational Performance: An Integrative View and Empirical Examination. Journal of Management Information Systems, v.20, n.1, p.179-228.

LEI, D.; HITT, M.; BETTIS, R. (1996). Dynamic core competences through meta-learning and strategic context. Journal of management, v.22, n.4, p.549.

LEITE, J.; PORSSE, M. (2003). Competição baseada em competências e aprendizagem organizacional: em busca da vantagem competitiva. Revista de Administração Contemporânea, v.7, p.121-141.

LEONE, N. (1999). As especificidades das pequenas e médias empresas. Revista de administração, v.34, n.2, p.91-94.

LEVINTHAL, D.; MARCH, J. (1993). The myopia of learning. Strategic Management Journal, p.95-112, Winter.

LEVINTHAL, D.; RERUP, C. (2006). Crossing an apparent chasm: Bridging mindful and less-mindful perspectives on organizational learning. Organization Science, v.17, n.4, p.502.

LEVITT, B.; MARCH, J. (1988). Organizational learning. Annual review of sociology, v.14, n.1, p.319-338.

LIAO, S.-H.; WU, C.-C. (2010). System perspective of knowledge management, organizational learning, and organizational innovation. Expert Systems with Applications, v.37, n.2, p.1096-1103. 
LICHTENTHALER, U. (2009). Absorptive Capacity, Environmental Turbulence, and the Complementarity of Organizational Learning Processes. The Academy of Management Journal ARCHIVE, v.52, n.4, p.822-846.

LOIOLA, E.; BASTOS, A. V. B. (2003). A produção acadêmica sobre aprendizagem organizacional no Brasil. Revista de Administração Contemporânea, v.7, p.181-201.

LOPEZ-NICOLAS, C.; SOTO-ACOSTA, P. (2010). Analyzing ICT adoption and use effects on knowledge creation: An empirical investigation in SMEs. International Journal of Information Management, v.30, n.6, p.521-528.

MADSEN, P. M.; DESAI, V. (2010). Failing to learn? The effects of failure and success on organizational learning in the global orbital launch vehicle industry. The Academy of Management Journal (AMJ), v.53, n.3, p.451-476.

MADUREIRA, C.; RODRIGUES, M. (2006). A Administração Pública do século XXI: Aprendizagem organizacional, mudança comportamental e reforma administrativa. Comportamento Organizacional e Gestão, v.12, n.2.

MARCH, J. (1991). Exploration and exploitation in organizational learning. Organization science, v.2, n.1, p.71-87, February.

MARTIN, D. et al. (2006). Noção de significado nas pesquisas qualitativas em saúde: a contribuição da antropologia; Notion of meaning in health qualitative research: the anthropology contribution. Rev. saúde pública, v.40, n.1, p.178-180.

MAZZALI, L. (2008). Conceito e espaço da pequena empresa na estrutura industrial: heterogeneidade e formas de inserção. Gest. Prod, v.15, n.3, p.591 - 603, set-dez.

MCGILL, M. E.; SLOCUM, J. W.; LEI, D. (1992). Management practices in learning organizations. Organizational Dynamics, v.21, n.1, p.5-17.

MEIJAARD, J.; BRAND, M. J.; MOSSELMAN, M. (2005). Organizational structure and performance in Dutch small firms. Small Business Economics, v.25, n.1, p.83-96.

MICHNA, A. (2009). The relationship between organizational learning and SME performance in Poland. Journal of European Industrial Training, v.33, n.4, p.356 - 370.

MINTZBERG, H. (1999). A estrutura simples. In: Estrutura e Dinâmica das Organizações. 2.ed. Lisboa. Cap.17, p.335 - 343.

MOODYSSON, J.; COENEN, L.; ASHEIM, B. (2008). Explaining spatial patterns of innovation: analytical and synthetic modes of knowledge creation in the Medicon Valley lifescience cluster. Environment and Planning A, v.40, n.5, p.1040-1056.

NAFUKHO, F. M.; GRAHAM, C. M.; MUYIA, M. H. (2009). Determining the relationship among organizational learning dimensions of a small-size business enterprise. Journal of European Industrial Training, v.33, n.1, p.32 - 51. 
NEVIS, E.; DIBELLA, A.; GOULD, J. (1995). Understanding organizations as learning systems. Sloan Management Review, v.36, n.Winter, p.73-85.

NONAKA, I. (1991). The knowledge-creating company. Harvard Business Review, n.NovDez, p.96 - 104.

NONAKA, I.; TOYAMA, R.; KONNO, N. (2000). SECI, Ba and Leadership: a Unified Model of Dynamic Knowledge Creation. Long Range Planning, v.33, n.1, p.5-34.

NONAKA, I.; VON KROGH, G. (2009). Tacit knowledge and knowledge conversion: Controversy and advancement in organizational knowledge creation theory. Organization Science, v.20, n.3, p.635-652.

NONAKA, I.; VON KROGH, G.; VOELPEL, S. (2006). Organizational Knowledge Creation Theory: Evolutionary Paths and Future Advances. Organization Studies, v.27, n.8, p.11791208, August 1, 2006.

O ESTADO DE SÃO PAULO (2012). Seis produtos são responsáveis por metade das exportações brasileiras. Disponível em: $<$ http://economia.estadao.com.br/noticias/economia,seis-produtos-sao-responsaveis-pormetade-das-exportacoes-brasileiras, 105640,0.htm>. Acesso em: 23 jun. 2012.

ÖRTENBLAD, A. (2001). On differences between organizational learning and learning organization. Learning Organization, The, v.8, n.3, p.125-133.

PEREIRA, L. C. B.; MOTTA, F. C. P. (1983). A organização Burocrática. In: Introdução à organização burocrática. 3.ed. São Paulo: Brasiliense. Cap.1, p.16 - 54.

PERIN, M. G. et al. (2006). Processo de aprendizagem organizacional e desempenho empresarial: o caso da indústria eletroeletrônica no Brasil. RAE eletrônica, v.5, n.2.

PERUSSI, S. (2006). Processo de Criação de Estratégicas em Pequenas Empresas de Base Tecnológica: proposta de modelo contemplando as fases de desenvolvimento de empresas do setor de fabricação de equipamentos médico-odontológicos. (Doutorado) Escola de Engenharia de São Carlos (EESC) - Departamento de Engenharia de Produção, Universidade de São Paulo (USP), São Carlos

PETTIGREW, A. (1992). The character and significance of strategy process research. Strategic Management Journal, v.13, n.S2, p.5-16.

PHILPOTT, E. (2008). Identifying innovation opportunities: using the internet to facilitate university-SME knowledge creation. International Journal of Knowledge Management Studies, v.2, n.3, p.285-302.

PILLANIA, R. K. (2008). Creation and categorization of knowledge in automotive components SMEs in India. Management Decision, v.46, n.10, p.1452 - 1464.

PISANO, G. (1994). Knowledge, integration, and the locus of learning: an empirical analysis of process development. Strategic Management Journal, v.15, n.Winter, p.85 - 100. 
POPADIUK, S.; CHOO, C. W. (2006). Innovation and knowledge creation: How are these concepts related? International Journal of Information Management, v.26, n.4, p.302-312.

ROBEY, D.; ROSS, J. W.; BOUDREAU, M.-C. (2002). Learning to Implement Enterprise Systems: An Exploratory Study of the Dialectics of Change. J. Manage. Inf. Syst., v.19, n.1, p.17-46.

ROCHA, M. (2008). Microempresas no Brasil: análise do período de 1984 a 2005. REAdRevista Eletrônica de Administração, v.14, n.2.

RYNES, S. L.; BARTUNEK, J. M.; DAFT, R. L. (2001). Across the great divide: Knowledge creation and transfer between practitioners and academics. The Academy of Management Journal, v.44, n.2, p.340-355.

SÁENZ, T. W.; CAPOTE, E. G. (2002). Ciência, Inovação e Gestão Tecnológica. Brasília. CNI/IEL/SENAI, ABIPTI.

SAMADDAR, S.; KADIYALA, S. S. (2006). An analysis of interorganizational resource sharing decisions in collaborative knowledge creation. European Journal of Operational Research, v.170, n.1, p.192-210.

SAMPAIO, J. D. R. (2001). A pesquisa qualitativa entre a fenomenologia e o empirismo formal. Revista de Administração, v.36, n.2, p.16 - 24.

SCHULZ, M. (2001). The uncertain relevance of newness: Organizational learning and knowledge flows. The Academy of Management Journal, v.44, n.4, p.661-681.

SCHULZE, A.; HOEGL, M. (2006). Knowledge Creation in New Product Development Projects. Journal of Management, v.32, n.2, p.210-236, April 1, 2006.

SEBRAE (2010). Inovação e Tecnologia. Disponível em: <http://www.sebrae.com.br/customizado/inovacao>. Acesso em: 15 dez. 2010.

SENAC-RS (2010). Um retrato das grandes, micro e pequenas. Excelência em Gestão, São Paulo, p. 28-40.

SENGE, P. M. (1990). A Quinta Disciplina: arte, teoria e prática da organização de aprendizagem. São Paulo: Editora Best Seller.

SENGE, P. M.; KURPIUS, D. (1993). The Fifth Discipline: The Art and Practice of the Learning Organization. Consulting Psychology Journal: Practice \& Research, v.45 Fall, n.4, p.31-32.

SHIH, K. H.; CHANG, C. J.; LIN, B. (2010). Assessing knowledge creation and intellectual capital in banking industry. Journal of Intellectual Capital, v.11, n.1, p.74-89.

SHINYASHIKI, G. T.; TREVIZAN, M. A.; MENDES, I. A. C. (2003). Sobre a criação e a gestão do conhecimento organizacional. Revista Latino-Americana de Enfermagem, v.11, n.4, p.499-506. 
ŠKERLAVAJ, M. et al. (2010). Intra-organizational learning networks within knowledgeintensive learning environments. Interactive Learning Environments, v.18, n.1, p.39-63.

SKERLAVAJ, M. et al. (2007). Organizational learning culture--the missing link between business process change and organizational performance. International Journal of Production Economics, v.106, n.2, p.346-367.

SPRAGGON, M.; BODOLICA, V. (2008). Knowledge creation processes in small innovative hi-tech firms. Management Research News, v.31, n.11, p.879 - 894.

STAKE, R. (1995). The Art of Case Study Research. SAGE Publications.

STAKE, R. E. (2008). Case Studies. In: Strategies of qualitative inquiry. 2.ed. Thousand Oaks: Sage Publications, Inc. Cap.5.

STEWART JR, W. et al. (1999). A proclivity for entrepreneurship:: A comparison of entrepreneurs, small business owners, and corporate managers. Journal of Business Venturing, v.14, n.2, p.189-214.

STOREY, D. J.; TETHER, B. S. (1998). New technological based firms in the European Union: an introduction. Research Policy, v. 26.

SZULANSKI, G. (2000). The Process of Knowledge Transfer: A Diachronic Analysis of Stickiness. Organizational Behavior and Human Decision Processes, v.82, n.1, p.9-27.

TEIXEIRA, L. P. (2003). Definição de pequena e média empresa no setor da construção brasileira. Belo Horizonte.

TERENCE, A. C. (2008). Processo de Criação de Estratégia em Pequenas Empresas: Elaboração de um mapa estratégico para as empresas de base tecnológica do pólo de São Carlos/SP. (Doutorado) - Escola de Engenharia de São Carlos (EESC) - Departamento de Engenharia de Produção, Universidade de São Paulo (USP), São Carlos.

THERIN, F. (2004). Leadership, Organizational Learning and Performance in Small and Medium Firms.

TIDD, J.; BESSANT, J.; PAVITT, K. (2008). Gestão da Inovação. Porto Alegre: Bookman.

TIPPINS, M. J.; SOHI, R. S. (2003). IT competency and firm performance: is organizational learning a missing link? Strategic Management Journal, v.24, n.8, p.745-761.

TOMAÉL, M.; ALCARÁ, A.; DI CHIARA, I. (2005). Das redes sociais à inovação. Ci. Inf, v.34, n.2, p.93-104.

TORRES, O. (2004). The SME concept of Pierre-André Julien: an analysis in terms of proximity. Piccola impresa, Small Business, v.17, n.2, p.51-62.

TURATO, E. (2005). Métodos qualitativos e quantitativos na área da saúde: definições, diferenças e seus objetos de pesquisa Qualitative and quantitative methods in health: definitions, differences and research subjects. Rev Saúde Pública, v.39, n.3, p.507-14. 
TUSHMAN, M. L.; O'REILLY III, C. A. (1996). Ambidextrous organizations: Managing evolutionary and revolutionary change. California management review, v.38, n.4, p.8-30.

UHLANER, L.; ZHOU, H.; TAN, S. (2007). Family orientation, strategy and organizational learning as predictors of knowledge management in Dutch SMEs.

VIEIRA, A. (2004). Cultura, poder e identidade nas organizações. Revista de Administração da FEAD-Minas, v.1, n.1, jun., p.61 - 75.

WADHWA, A. N. U.; KOTHA, S. (2006). Knowledge creation through external venturing: evidence from the telecommunications equipment manufacturing industry. The Academy of Management Journal ARCHIVE, v.49, n.4, p.819-835.

WANG, C. L.; AHMED, P. K. (2007). Dynamic capabilities: A review and research agenda. International Journal of Management Reviews, v.9, n.1, p.31-51.

WANG, J. et al. (2010). An exploratory factor analysis of workplace learning, job satisfaction, and organizational commitment in small to midsize enterprises in Taiwan. Human Resource Development International, v.13, n.2, p.147 - 163.

WINTERS, R.; STAM, E. (2007). Innovation Networks of High Tech SMEs: Creation of Knowledge but No Creation of Value. SSRN eLibrary.

YEO, R. K.; MARQUARDT, M. J. (2010). Problems as Building Blocks for Organizational Learning: A Roadmap for Experiential Inquiry. Group \& Organization Management, v.35, n.3, p.243-275, June 1, 2010.

ZHANG, M., MACPHERSON, A. e JONES, O. (2006). Conceptualizing the learning process in SMEs. International Small Business Journal, v.24, n.3, p.299.

ZICA, R.; MARTINS, H. (2008). Sistema de garantia de crédito para micro e pequenas empresas no Brasil: proposta de um modelo. Revista de Administração Pública, v.42, p.181-204.

ZIMAN, J. (1979). O homem e a ciência: conhecimento público. São Paulo: Editora da Universidade de São Paulo. 